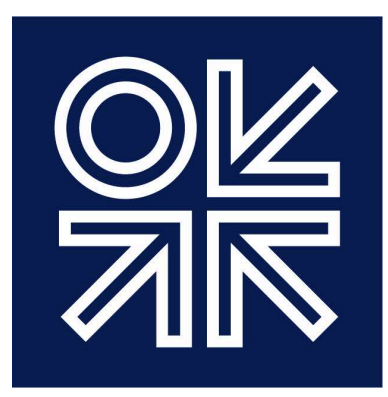

THE OXFORD INSTITUTE FOR ENERGY STUDIES

February 2014

\title{
Mainstreaming Climate Policy in the Gulf Cooperation Council States
}

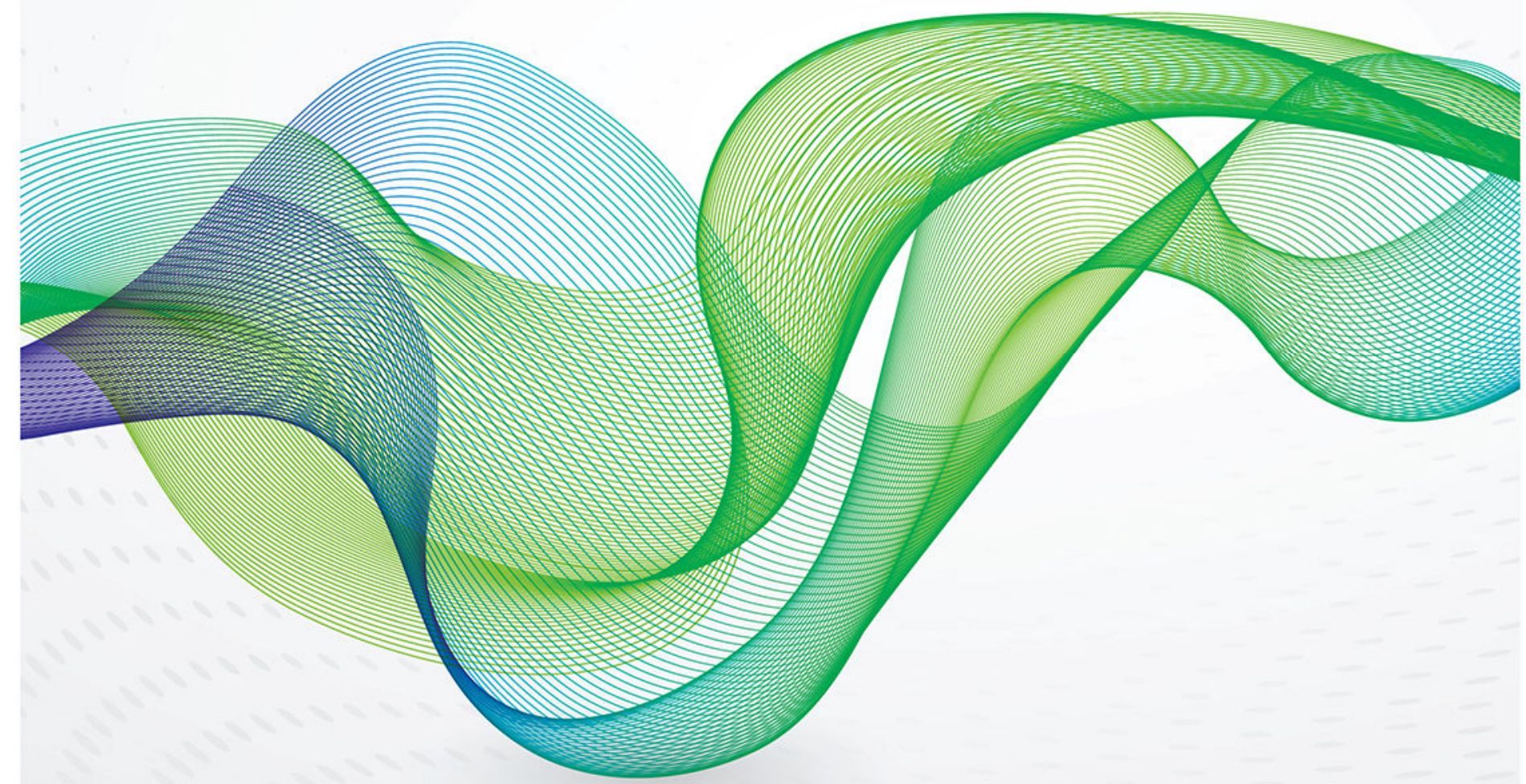

Dr. Mari Luomi* 
The contents of this paper are the authors' sole responsibility. They do not necessarily represent the views of the Oxford Institute for Energy Studies or any of its members.

Copyright $\odot 2014$

Oxford Institute for Energy Studies

(Registered Charity, No. 286084)

This publication may be reproduced in part for educational or non-profit purposes without special permission from the copyright holder, provided acknowledgment of the source is made. No use of this publication may be made for resale or for any other commercial purpose whatsoever without prior permission in writing from the Oxford Institute for Energy Studies.

ISBN 978-1-907555-91-6 


\section{Contents}

1 Reversing the Viewpoint: From International Zero-Sum to National Win-Win ..........................1

2 Climate Policy at Different Levels: Mechanisms and Measures ................................................. 4

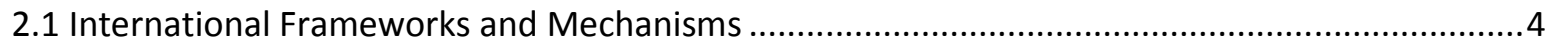

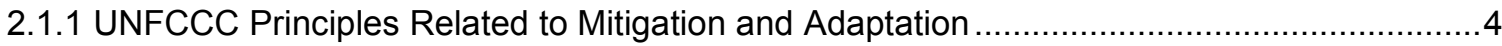

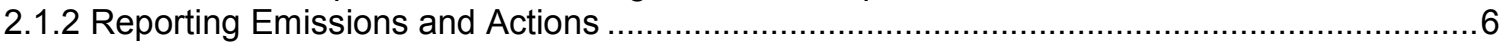

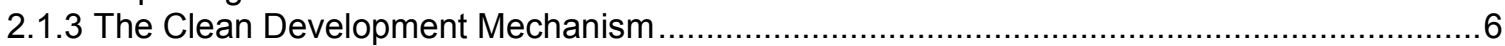

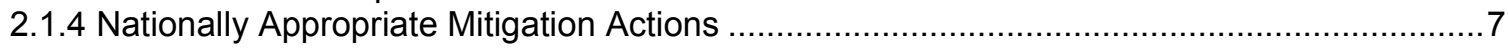

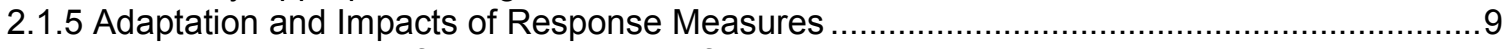

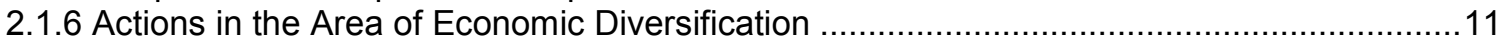

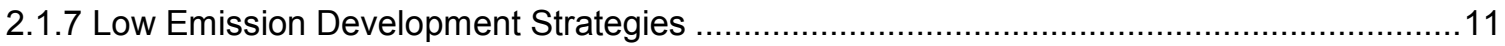

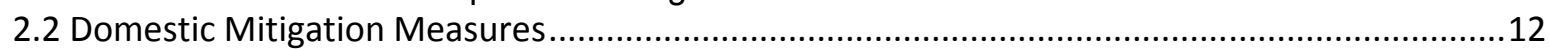

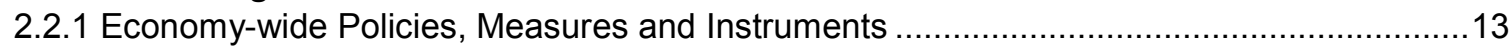

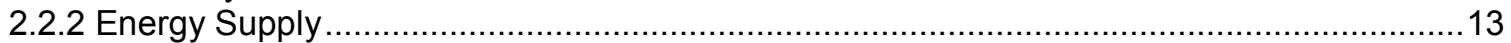

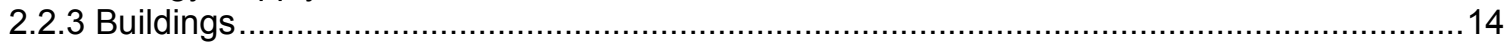

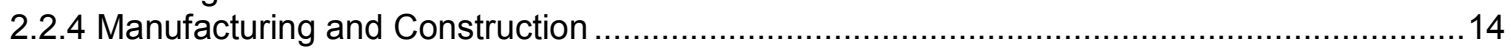

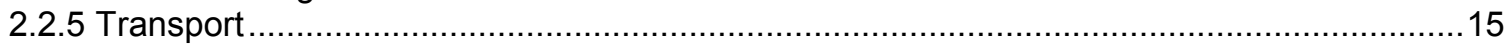

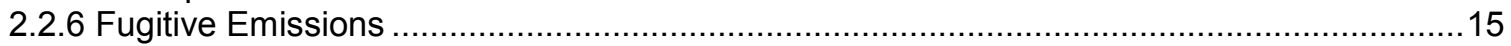

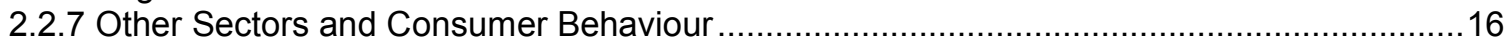

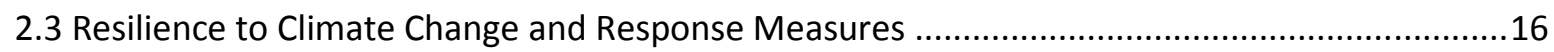

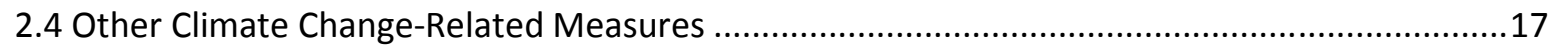

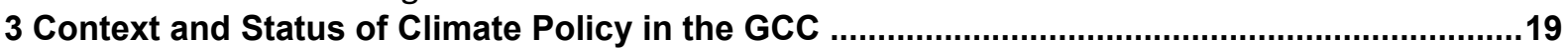

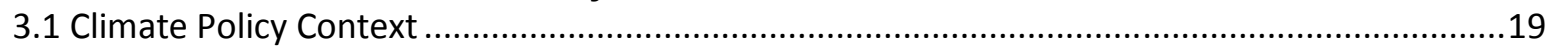

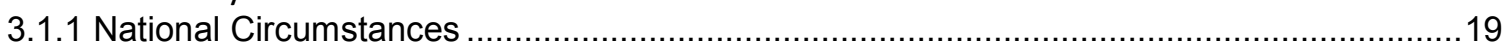

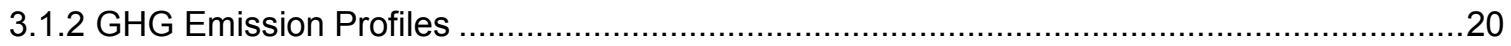

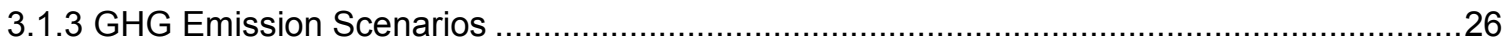

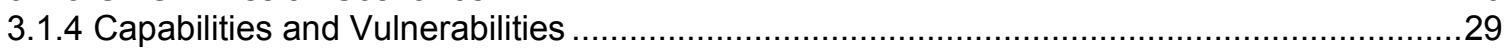

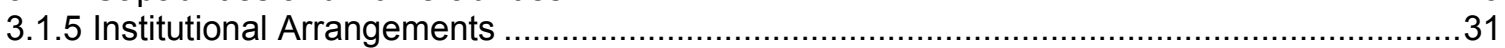

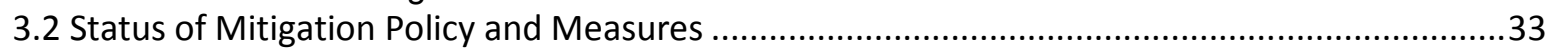

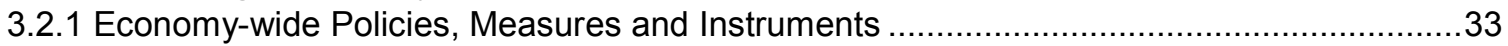

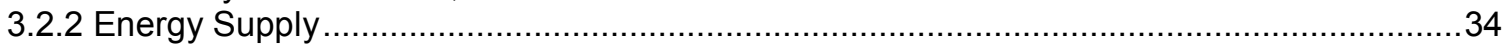

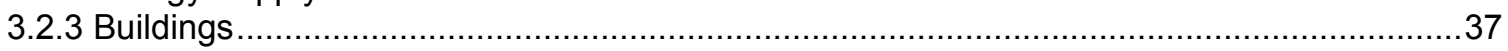

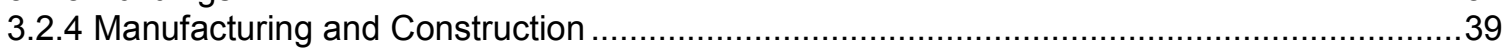

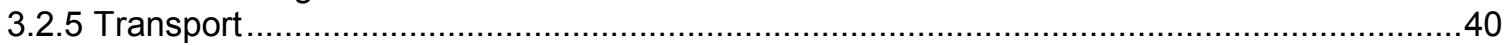

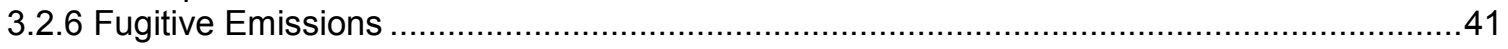

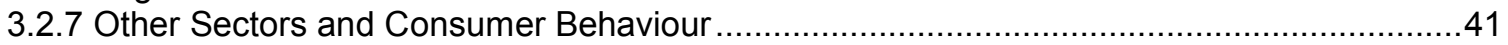

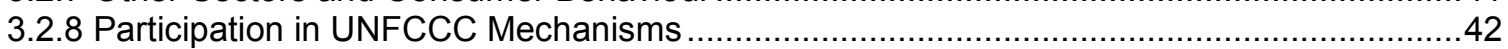

3.3 Status of Adaptation and Response Measures-Related Policy and Measures ...........................44

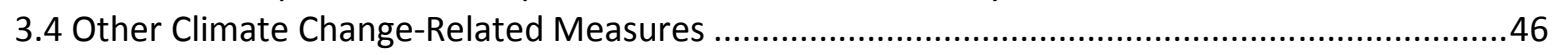

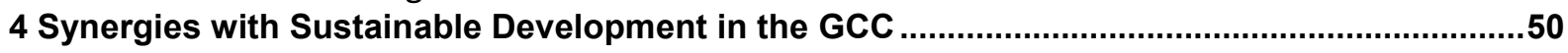

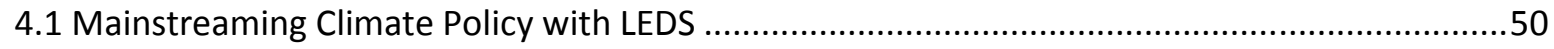

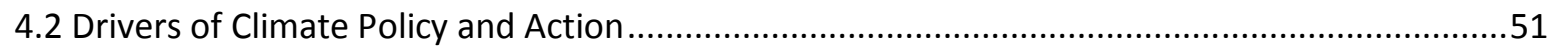

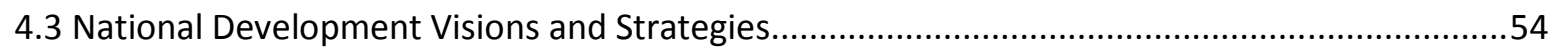

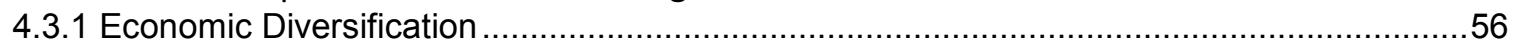

4.3.2 Energy and Natural Resource Security and Policy .......................................................56

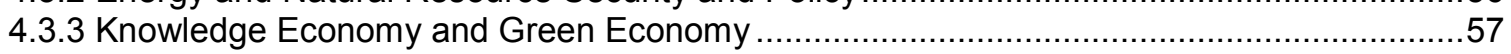

4.4 Towards Low-Emission, Climate-Resilient Development …......................................................59

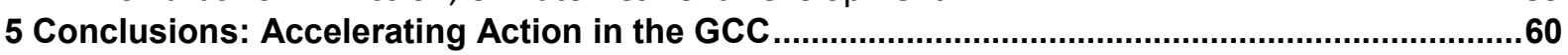

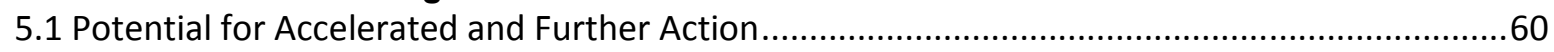

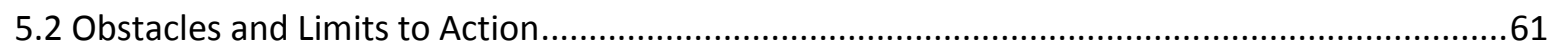

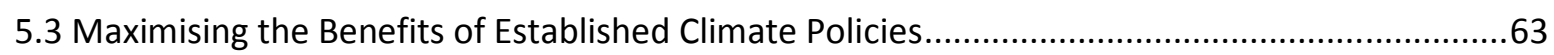

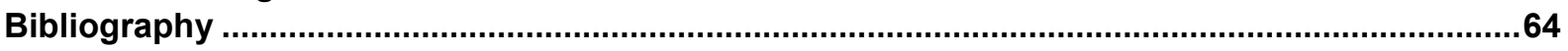




\section{Figures}

Figure 1: Total GHG emissions in $\mathrm{MtCO}_{2} \mathrm{e}$ in the GCC states, 2000-2010.................................22

Figure 2: Shares of energy sources in electricity generation in the GCC states, 2000 \& 2010...........24

Figure 3: Shares of energy sources in primary energy supply in the GCC states, $2000 \& 2010 \ldots \ldots \ldots .25$

\section{Tables}

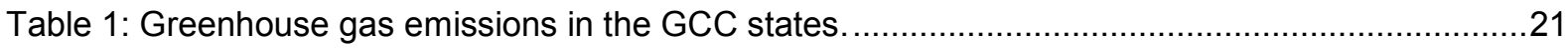

Table 2: Energy sector greenhouse gas emissions in the GCC states, 2009.................................23

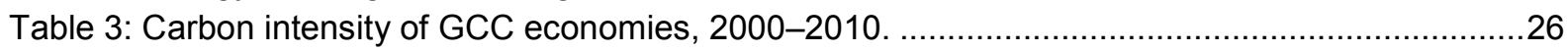

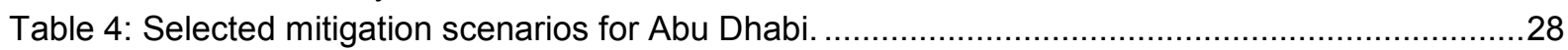

Table 5: Government entities responsible for climate change policy. ..............................................

Table 6: CDM projects in validation and registered in the GCC countries, October 2013.................43

Table 7: Research institutions with climate policy-relevant focus in three GCC states.......................47

Table 8: Drivers of climate action grounded in broader socioeconomic priorities in the GCC. ............53

Table 9: National development visions and strategies of three GCC states. ......................................54 


\section{Reversing the Viewpoint: From International Zero-Sum to National Win-Win}

In the recent years, the Gulf Cooperation Council (GCC) states have begun actively exploring opportunities for proactive participation in the global low-carbon transition. This shift in attitude has been prompted by the simultaneous rise of climate change on the international energy agenda and the GCC states' economic and population boom in the 2000s, which began to put unprecedented strain on their natural resource security and 'natural sustainability'. ${ }^{1}$ Participating in the ongoing international discussion on the possible ways forward on climate change action, this study proposes a bottom-up approach to the issue. Grounded in the countries' national circumstances, capabilities and vulnerabilities, the study approaches the topic from the perspective of the opportunities inherent in integrating the goals of low-emission, resource-efficient and climate-resilient development into developing countries' sustainable development goals. Through a pragmatic examination of the domestic level developments in this area, in key GCC states, the paper addresses three questions: what kind of climate policies and actions are the GCC states already taking; what co-benefits could these bring if clearly aligned with other sustainable development policy goals, including economic diversification; and what is the scope for further action? By pointing out the opportunities for enhanced domestic action to cut emissions and increase resilience to climate change and its international mitigation, this paper seeks to encourage a pragmatic conversation on the opportunities of enhanced climate action and low-carbon transitions in the states of the region. Fundamentally, it argues that, despite the scale of the challenge in the GCC states and the inherent tension between their vast oil wealth and international climate change mitigation, if bold decisions are taken promptly, the scope for change and benefits is broad.

At the international level, most countries still perceive committing to climate action as a zero-sum game, focused on avoiding concessions to protect national economic competitiveness or 'sustainable development'. Another approach to climate action is focusing on the 'win-wins' and working, at the domestic level, with the opportunities of low carbon, resource efficiency and climate resilience and the synergies of combining these with other sustainable development goals. ${ }^{2} \mathrm{~A}$ number of developed countries in Europe and developing countries from Latin America and Africa and the small island states have already adopted this stance ${ }^{3}$ In the GCC, the United Arab Emirates' (UAE) green growth strategy represents this kind of thinking. ${ }^{4}$

Despite many positive signs over the past seven years of shifts towards an opportunities-focused approach, the GCC, as a bloc, still feels hesitant about registering even voluntary actions at the international level. The Doha UN climate conference in late 2012 saw a partial shift in this sense, with four GCC states announcing their readiness to place existing economic diversification actions and plans with climate change co-benefits to international scrutiny. However, as the 2013 UN climate conference in Warsaw drew to a close, no actions had been notified under this initiative, indicating a shift in focus to the next big round of UN climate negotiations in 2015, in which all countries are expected to come up with commitments to prevent dangerous climate change beyond 2020.

\footnotetext{
${ }^{1}$ Mari Luomi, The Gulf Monarchies and Climate Change: Abu Dhabi and Qatar in an Era of Natural Unsustainability (London: Hurst, 2012).

${ }^{2}$ E.g. Christiana Figueres, 'Christiana Figueres: Global Deal on Climate Change Complex But Possible', RTCC (5 February 2013); Aaditya Mattoo and Arvind Subramanian, Equity in Climate Change: An Analytical Review, Policy Research Paper 5283 (Washington D.C., The World Bank, 2010).

${ }^{3}$ Institute for Sustainable Development Reporting Services (IISD-RS), Earth Negotiations Bulletin, Vol. 12 , No. 546, 25.

${ }^{4}$ Hiwar, 'Hiwar Session: UAE Vision 2021 and the Green Growth Strategy,' Summary Report (Abu Dhabi Sustainability Group, May 2013); Binsal Abdul Kader, 'UAE to Announce Action Plan for Green Growth Strategy by End of This Year,' Gulf News (15 May 2013).
} 

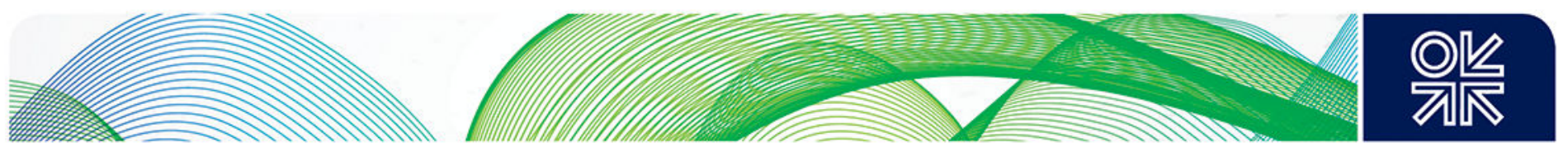

Whilst science should always guide global climate action, many argue that focusing on how to divide the 'remaining global carbon budget' between countries alone is not politically feasible. ${ }^{5}$ For this reason, the international climate negotiations are currently starting to look into country-defined contributions, which would later be adjusted to science. Given the sad state of existing emission reduction pledges, preventing a global temperature rise of over $2^{\circ} \mathrm{C}$ through collective action seems an increasingly frustrating exercise. However, at the same time, some hope is brought by the vast amounts of low-carbon planning and activities in both developed and developing countries: the United States, for example is achieving major emission reductions from switching from coal to natural gas in the power sector, whilst the growth of emissions in China - which has been particularly high over the past decade - is starting to slow owing to efforts to increase energy efficiency and install low-carbon generating capacity. ${ }^{6}$ Over the past three years, as part of a national plan to increase energy security and build a competitive solar industry, India has installed 1.8 GW of solar power, with plans for a total of $20 \mathrm{GW}$ by 2020 , and South Korea has since 2008 based its national planning strategy on the concept of green growth, which aims to promote environmentally sustainable growth whilst enhancing the quality of life and reducing greenhouse gas emissions. ${ }^{7}$ A number of smaller countries too are pursuing ambitious low carbon plans: Costa Rica has created a national carbon market towards its low-carbon goal by 2021; Norway has declared it aims at carbon neutrality by 2030; and Morocco aims at a renewable energy share of 42 per cent $(6 \mathrm{GW})$ of its electricity generation capacity by 2020 , with $325 \mathrm{MW}$ of capacity already installed and $1 \mathrm{GW}$ under construction in $2012{ }^{8}$ Many other promising examples could be mentioned, including some from the areas of adaptation, finance, technology transfer and capacity building - other key areas of international climate action - but the above-mentioned plans and actions alone serve to show how countries are addressing the mitigation side of climate change, as part of a broader energy sector transition, through specific energy sector strategies or plans, or embedded in national development and economic strategies.

The GCC states' recognition of the synergistic nexus between climate action and economic diversification is not new and finds its recent manifestations in both the recent years' long-term development plans $^{9}$ and the policies and positions of these states vis-à-vis the UN climate negotiations. ${ }^{10}$ Linking long-term development goals and climate action (mitigation and adaptation) through economic diversification efforts therefore seems justifiable and rational for countries as deeply and multidimensionally dependent on fossil fuels as the six GCC states. Furthermore, climate actions that are grounded in and streamlined with long-term national economic development and energy policy goals stand on a stronger basis than those reliant on external support or funding or a weaker motivation such as prestige. ${ }^{11}$

As with the global carbon budget approach, an exclusive focus on the international level alone can be counterproductive for parallel domestic debates. This is the case in particular for the GCC states, given their parallel concerns over their future hydrocarbon revenues and creating 'precedents' for

\footnotetext{
${ }^{5}$ Fiona Harvey, 'IPCC's "Carbon Budget” Will Not Drive Warsaw Talks, Says Christiana Figueres', The Guardian (24 October 2013).

International Energy Agency (IEA), Redrawing the Energy-Climate Map. World Energy Outlook Special Report (Paris: OECD/IEA, 2013), 26-7.

Sushma U. N., 'Solar Power's Moment under the Indian Sun', The Times of India (30 September 2013); OECD

'Green Growth in Action: Korea' [http://www.oecd.org/korea/greengrowthinactionkorea.htm], accessed in October 2013.

${ }^{8}$ Michelle Soto M., 'Costa Rica crea mercado local de carbono', La Nación (11 September 2013); State of the Environment Norway, 'Climate Change' [http://www.environment.no/Goals-and-indicators/Goals-andindicators/Climate-change/], accessed in October 2013; Regional Center for Renewable Energy and Energy Efficiency, Arab Future Energy Index, AFEX 2013: Renewable Energy (Cairo, RCREEE, 2013), 33, 36. Norway's goal is conditional on an ambitious global agreement.

See e.g. General Secretariat for Development Planning (Qatar), Qatar National Vision 2030 (Doha: GSDP, 2008); UAE Cabinet, 'A Green Economy for Sustainable Development' [http://www.uaecabinet.ae/], accessed in December 2012.

Council of Arab Ministers Responsible for the Environment, Statement on Climate Change (2009), Arabic; Mari Luomi, Bargaining in the Saudi Bazaar: Common Ground for a Post-2012 Climate Agreement?, FIIA Briefing Paper 48 (Helsinki: The Finnish Institute of International Affairs, 2009).

Examples of the former are the alignment of the EU's energy and climate policies and South Korea's green growth model.
} 

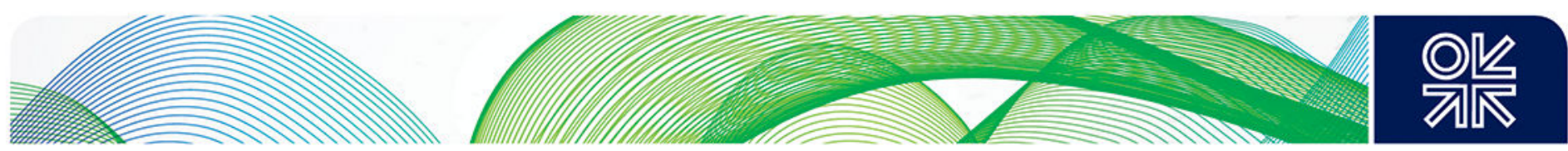

stringent domestic mitigation commitments, for example by publishing baselines for emission reductions or one making unilateral reduction pledges. This paper argues that a country's national climate actions can be 'safely' analysed in the context of national circumstances without necessarily taking a stance in the international debate on what the 'fair share' of each country should be. Aside from whether they are classified as developed or developing, states' responses to climate change will depend on a variety of societal factors or 'national circumstances', ranging across wealth, economic structure, development priorities, natural resource endowments, and climatic conditions. Once these circumstances have been aligned with opportunities for climate action, the next step (beyond the scope of this paper) will be for each country to make the relevant political decisions regarding domestic policies and international participation. This paper aims to provide a pragmatic look at how the GCC states can combat climate change at home by looking for opportunities for low-carbon, resource-efficient and climate-resilient development in the context of national development priorities, including sustainable development.

The next section starts by setting the international context for climate action by examining the existing frameworks for action and support under the UN Framework Convention on Climate Change (UNFCCC) and beyond. Subsequently, the section presents a range of sector-based domestic policies and measures identified by the Intergovernmental Panel on Climate Change (IPCC), UNFCCC, and others for combating climate change. The third section of the study builds a comprehensive climate action profile for the GCC states, with analyses of national circumstances, capabilities and vulnerabilities, and GHG emissions, including future projections. For three of the most active GCC states in this area, the UAE, Saudi Arabia and Qatar, the section presents a comprehensive, sectoral assessment of existing measures aimed at or with benefits for emission reductions and climate resilience. The fourth section examines the concepts of climate policy mainstreaming and low-emission development strategies (LEDS) and argues that these help in aligning climate change-related policy aims with existing economic development visions and plans in a way that creates positive synergies. The final section looks at potential for further action, including related obstacles and opportunities. 


\section{Climate Policy at Different Levels: Mechanisms and Measures}

For contextualising the paper in the area of climate policy, the first part of this section provides an overview of aspects of the international climate change regime of relevance for the GCC states, including: legal principles; global emission trajectories; relevant mitigation-related instruments and incentives; the issue of response measures and economic diversification; and low-emission development strategies. The second part of the section provides an overview of domestic-level climate policies and measures relevant for the GCC states, with an emphasis on mitigation but including adaptation (to response measures) and other measures. The section also discusses the issues of adaptation and means of implementation of climate action.

\subsection{International Frameworks and Mechanisms}

Since the early 1990s, action to mitigate and adapt to climate change has been discussed in the framework of an international regime, the United Nations Framework Convention on Climate Change (UNFCCC) that has near-universal participation and has produced a legally binding protocol with binding emission reduction targets for developed countries. Despite its increasing sophistication and complexity in terms of encouraging increased mitigation action by developed countries and providing incentives and support for developing countries to curb their emissions growth and adapt to climate change, the regime has yet to produce a legal framework that would set international pledges in line with science, in order to avoid catastrophic climate change. The GCC countries, classified in this regime as developing countries, have been engaging in negotiations since the 1990s.

\subsubsection{UNFCCC Principles Related to Mitigation and Adaptation}

The UNFCCC was adopted in 1992 with the aim of stabilising 'greenhouse gas concentrations in the atmosphere at a level that would prevent dangerous anthropogenic interference with the climate system'. ${ }^{12}$ The main scientific input to the UNFCCC's work comes from the Intergovernmental Panel on Climate Change (IPCC), which is in the process of launching its Fifth Assessment Report (AR5). The IPCC AR5 defines the limit for total emissions since the onset of the industrial era, if humanity is to have a good (over $66 \%$ ) chance of avoiding dangerous climate change (broadly considered as $2^{\circ} \mathrm{C}$ of warming), as $1,000 \mathrm{Gt}$ of carbon and notes that the world has already used up $52 \%$ of this 'budget'. ${ }^{13}$ Moreover, some estimate that the remaining might be spent in as little as three decades. ${ }^{14}$

According to IPCC's Fourth Assessment Report (AR4), from 2007, in order to increase the probability of staying below $2^{\circ} \mathrm{C}$ of warming, developed countries will need to cut their emissions by 25-40 percent below 1990 levels by 2020 and 80-95 percent below 1990 levels by 2050. In these same time frames, developing countries will need to substantially deviate from baseline emission trajectories. ${ }^{15}$ Given that, in the coming decades, growth in emissions will be taking place mostly in non-OECD countries, achieving safe levels of greenhouse gas (GHG) concentrations will not be possible even if developed countries cut their emissions to zero. ${ }^{16}$ Hence, it is broadly accepted that mitigation actions

\footnotetext{
12 UNFCCC, United Nations Framework Convention on Climate Change (1992), article 2.

${ }^{13}$ Equal to 3,670 $\mathrm{GtCO}_{2}$. Thomas F. Stocker et al. (eds.), Climate Change 2013: The Physical Science Basis. Summary for Policymakers. Working Group I Contribution to the Fifth Assessment Report of the IPCC (Cambridge, UK and New York, US: Cambridge University Press, 2013), 25.

${ }^{4}$ Kelly Levin, 'World's Carbon Budget to Be Spent in Three Decades', WRI Insights (27 September 2013) [http://insights.wri.org/news/2013/09/world\%E2\%80\%99s-carbon-budget-be-spent-three-decades], accessed in November 2013.

S. Gupta et al., 'Policies, Instruments and Co-operative Arrangements', in B. Metz et al. (eds.), Climate Change 2007: Mitigation. Contribution of Working Group III to the Fourth Assessment Report of the IPCC (Cambridge, UK and New York, US: Cambridge University Press, 2007), 776.

${ }^{6}$ Mattia Romani, James Rydge and Nicholas Stern, Recklessly Slow or a Rapid Transition to a Low-Carbon Economy? Time to Decide, Policy Paper, (Grantham Research Institute, 2012), 12. Since 1990, Non-Annex I countries' share of global emissions has increased from $33 \%$ to $55 \%$. Ibid., 15 .
} 

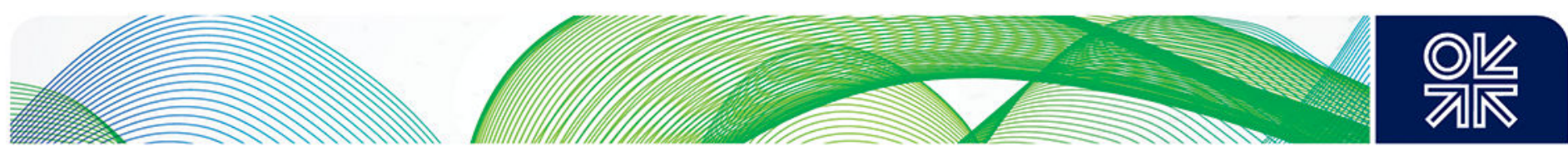

are required from developing countries as well, alongside actions to adapt to the impacts of climate change, and that these must be supported by finance, technology transfer, and capacity building, also known as means of implementation. ${ }^{17}$

Countries in the UNFCCC are divided into developed (Annex I), consisting of OECD members in 1992 and economies in transition (e.g. Russia and Eastern Europe), and developing (non-Annex I). All Arab countries, including the six GCC states, are hence classified as non-Annex I countries. The convention is guided by a number of key principles, including: equity; common but differentiated responsibilities and respective capabilities (CBDR-RC, or CBDR); needs and circumstances, and right to sustainable development of developing countries; precautionary action; and an open international economic system. ${ }^{18}$ In short, these mean that developed countries must lead in climate changerelated actions, the priorities of developing countries should be respected, lack of full scientific certainty should not prevent or lead to postponing action, and climate measures should not constitute barriers to international trade.

All GCC states are parties to the UNFCCC and its legally binding instrument, the Kyoto Protocol. The UNFCCC convention includes commitments for all parties, but defines a quantified emissions reduction goal only for developed countries (Annex I). ${ }^{19}$ Similarly, the Kyoto Protocol, adopted in 1997 and amended for a second commitment period in 2012, only contains emissions reduction commitments to developed countries listed in its Annex B. Currently, these states only account for 15 percent of global emissions and have agreed to cut their emissions by a total of 18 percent by $2020 .^{20}$ Complicating the picture further is the fact that, in 2010, non-OECD countries accounted for 69 percent of total energy-related $\mathrm{CO}_{2}$ emissions in the world. ${ }^{21}$ The same year, developing countries' cumulative GHG emissions (1850-2010) are estimated to have been 48 percent of global emissions and are expected to amount to 51 percent by $2020 .^{22}$

The convention establishes that the extent of developing countries' actions depends on the availability of financial resources and technology transfer from developed countries. ${ }^{23}$ Adaptation, and support for implementing related measures, is another crucial area for developing countries. In order to enable mitigation and adaptation actions in developing countries, developed countries have committed to leveraging US $\$ 100$ billion in climate finance each year, from 2020. Importantly for the GCC countries, the convention also mentions fossil fuel-revenue dependent countries as a group with specific needs and concerns that relate to the negative impacts of climate change and/or response measures (or implementation of mitigation activities) and which could be met by funding, insurance, technology transfer and economic diversification, among other measures. ${ }^{24} 25$

There have been some advances towards universal participation in the past years, both bottom-up and top-down: currently, over 90 developed and developing countries, representing approximately 80 percent of global emissions, have presented voluntary mitigation pledges to the UNFCCC for the

\footnotetext{
${ }^{17}$ Whilst studies have been published on the estimated total reductions needed from developing countries (see e.g. M. den Elzen and N. Höhne, 'Reductions of Greenhouse Gas Emissions in Annex I and non-Annex I Countries for Meeting Concentration Stabilisation Targets', Climate Change, 91 (2008), 249-74), this paper will not partake in this debate.

${ }^{18}$ UNFCCC, UNFCCC, article 3

${ }^{19}$ UNFCCC, UNFCCC, article 4 and Annex I.

${ }^{20}$ Niklas Höhne and Caroline de Vit, What to Expect from Climate Negotiations in Warsaw?, Ecofys Policy Update, Issue V, (October 2013), 1.

US Energy Information Administration (US EIA), 'International Energy Outlook 2013'

[http://www.eia.gov/forecasts/ieo/emissions.cfm], accessed in October 2013.

PBL Netherlands Environmental Assessment Agency, 'Countries' Contributions to Climate Change: Effect of Accounting for All Greenhouse Gases, Recent Trends, Basic Needs and Technological Progress' (31 October 2013) [http://www.pbl.nl/en/publications/countries-contributions-to-climate-change], accessed in November 2013. ${ }^{23}$ UNFCCC, UNFCCC, article 4.7.

${ }^{24}$ UNFCCC, UNFCCC, articles 4.8 and 4.10.

${ }^{25} \mathrm{~A}$ third, emerging area of action is loss and damage related to those adverse effects of climate change that go beyond what is solvable by adaptation, including extreme and slow onset events. For this purpose, the UN climate conference of 2013 established a specific mechanism. UNFCCC, Decision -/CP.19. Warsaw international mechanism for loss and damage associated with climate change impacts.
} 

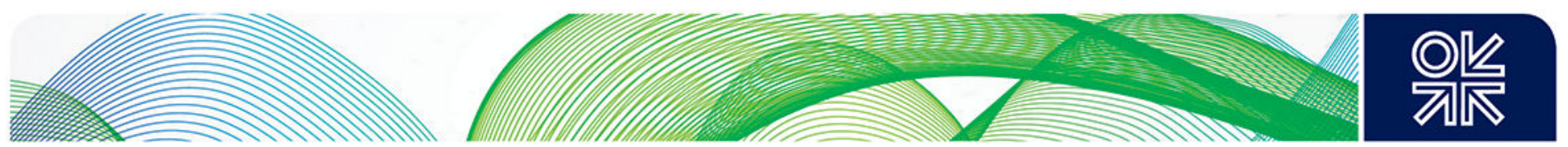

period until $2020 .^{26}$ In 2011, the Conference of the Parties (COP) to the UNFCCC agreed to work towards a universal, legally binding agreement with emission commitments for all parties. This agreement would be agreed upon by 2015 and enter into force in $2020{ }^{27}$ At present, important issues remain to be resolved, including the architecture of the agreement, the process and principles by which countries present emission reduction pledges for the post-2020 period, and how the regime interacts with and/or influences these. ${ }^{28}$

\subsubsection{Reporting Emissions and Actions}

The Convention establishes that all parties shall communicate to the COP information on national greenhouse gas emissions and steps taken or planned to implement the convention. So far, most non-Annex I countries have submitted two national communications (NCs), with emission baselines for $1900 / 1994$ and $2000 .{ }^{29}$ As a result, for most developing countries, the 13 years' absence of nationally verified information for emissions makes it difficult to establish projections, other than ones based on externally produced and/or unofficial data and estimates.

The COPs in 2010-2011 decided that developing countries should also submit biennial update reports, containing a national greenhouse gas inventory, and information on mitigation actions, needs and support received. The first reports are due in December 2014 and should contain an inventory for the year 2010, or later. The BURs will also be subject to international consultation and analysis (ICA), in a non-punitive manner, in order to increase the transparency of reported mitigation actions and their effects. ${ }^{30}$

\subsubsection{The Clean Development Mechanism}

Agreed in 1997 and operationalised in 2001, the Clean Development Mechanism (CDM) of the Kyoto Protocol has to date provided important incentives for emission reduction projects with private sector participation in developing countries. The CDM is designed to cut emissions cost-efficiently through emissions-avoidance projects in developing countries. These projects generate certified emission reduction (CER equal to one tonne of $\mathrm{CO}_{2}$ ) credits that developed countries can purchase and use towards their Kyoto emission reduction targets, for offsetting emissions. The CDM has not been too successful in terms of regional distribution or in medium-size and small developing countries, with over 80 percent of the projects developed in China, India, Brazil and Mexico. ${ }^{31}$ By October 2013, a total of 7,289 CDM projects had been registered by the CDM Executive Board, of which only 121 were in the Middle East and North Africa (MENA) region and 21 in the GCC states. Projects registered by the end of 2012, in turn, amounted to 2,219 million tonnes of $\mathrm{CO}_{2} \mathrm{e}$ avoided - equal to 4.7 percent of global GHG emissions (2010). Of these avoided emissions, 15 million tonnes of $\mathrm{CO}_{2} \mathrm{e}$, or 0.6 percent of the global total avoided emissions, were contributed by registered CDM projects in the GCC states. ${ }^{32}$

\footnotetext{
${ }^{26}$ European Council, Conclusions on Preparations for the 19th session of the Conference of the Parties (COP 19) to the United Nations Framework Convention on Climate Change and the $9^{\text {th }}$ Session of the Meeting of the Parties to the Kyoto Protocol (Warsaw, 11-22 November 2013) (Luxembourg, 14 October 2013), 2.

${ }^{27}$ Parties agreed to develop a universal 'protocol, legal instrument or other outcome with legal force'. UNFCCC, Decision 1/CP.17, document FCCC/CP/2011/9/Add.1.

${ }^{28}$ Personal correspondence with experts on the UNFCCC, October 2013.

${ }^{29}$ UNFCCC, 'Relevant guidelines/manuals related to NCs and BURs from non-Annex I Parties'

[http://unfccc.int/national_reports/non-annex_i_natcom/guidelines_and_user_manual/items/2607.php]; 'NonAnnex I national communications' [http://unfccc.int/national_reports/non-annex i natcom/items/2979.php], both accessed in October 2013.

${ }^{30}$ UNFCCC, Decision 2/CP.17, paragraphs 39-44 and 56-62, document FCCC/CP/2011/9/Add.1.

${ }^{31}$ Xander van Tilburg et al., Status Report on Nationally Appropriate Mitigation Actions (NAMAs): Mid-year Update June 2013 (Mitigation Momentum, 2013), 11.

32 Joergen Fenhann, CDM Pipeline, 1 October 2013 (UNEP Risoe Centre, 2013). Notably, nearly two thirds of issued CERs were for projects in China. Nb. latest data available for global GHG emissions (including land use change and forestry) was for 2010. Source: World Resources Institute (WRI), 'Climate Analysis Indicators Tool (CAIT 2.0)' [cait2.wri.org/], accessed in October 2013
} 

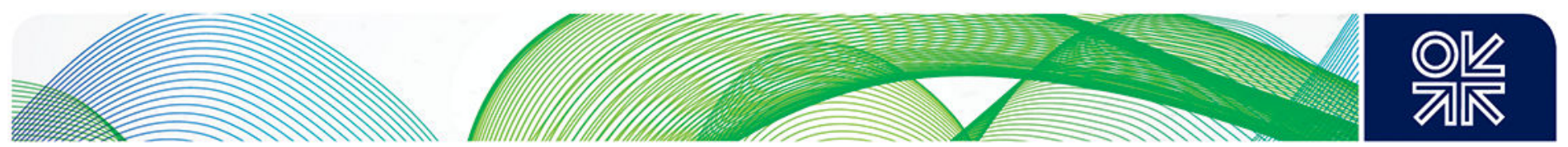

The inclusion of carbon capture and storage (CCS) as an approved CDM methodology was strongly supported in the UNFCCC negotiations by most GCC states since the mid-2000s. In 2010, the COP decided to make eligible CCS in geological formations, which was hoped in the GCC to provide the needed push for CCS demonstration projects and deployment, given the high cost of the technology option. ${ }^{33}$ Even so, interest has remained relatively low. In addition to weak capacity and knowledge on the mechanism ${ }^{34}$ this relative indifference can be attributed to the low CER prices: since the late 2000s' global economic crisis, the price of CERs has collapsed due to oversupply of credits compared to demand: from their at peak in 2008, at over $€ 20$, by November 2013, one (secondary) CER sold at a mere $€ 0.32$, making the mechanism increasingly unattractive despite a decision in 2012 to extend the mechanism until 2020. Moreover, some estimates predict that the current oversupply situation will persist through $2020 .^{35}$

In addition to the CDM, at least two GCC-relevant market approaches to mitigation actions in developing countries are currently emerging: the New Market Mechanism (NMM), for offsetting emissions in a centralised manner, and the Framework for Various Approaches (FVA), an umbrella for a decentralised global carbon market. Both are currently still under discussion in the UNFCCC. ${ }^{36}$

\subsubsection{Nationally Appropriate Mitigation Actions}

First coined in Bali in 2007, Nationally Appropriate Mitigation Actions (NAMAs) have become the de facto main vehicle for developing countries to communicate their voluntary mitigation commitments and related financing needs to the UNFCCC. As agreed in 2010, they aim 'at achieving a deviation in emissions relative to business-as-usual emissions in 2020, ${ }^{37}$ Sharma and Desgain define NAMA as 'any mitigation action tailored to the national context, characteristics and capabilities, and embedded in national sustainable development priorities' ${ }^{38}$ NAMAs are not legally binding at the international level (as long as they are not included in a COP decision), and they are determined nationally and implemented voluntarily by developing countries whose governments' submit information on these actions to the UNFCCC, via its secretariat. ${ }^{39}$ They are, however, subject to measurement, reporting and verification (MRV) on either domestic or international levels. ${ }^{40}$ Importantly, Sharma and Desgain note that, given the lack of compliance mechanisms, NAMA's are 'morally self-binding' and their importance 'political, with limited practical implications' from non-compliance. ${ }^{41}$

NAMAs can be supported or unilateral. In the former case, countries can seek support (i.e. private and public investments, including from international institutions) through the NAMA Registry, managed by the UNFCCC Secretariat where domestically funded, unilateral NAMAs can also be registered for recognition. Support can be financial, technological or capacity-building related and it can go for the preparation or implementation of NAMAs. ${ }^{42} \mathrm{~A}$ third concept of credited NAMAs is also

\footnotetext{
${ }^{33}$ UNFCCC, Decision 10/CMP.7, document FCCC/KP/CMP/2011/10/Add.2.

34 See e.g. Salman Zafar, 'CDM Projects in MENA Region', EcoMENA (7 April 2013).

${ }^{35}$ Ecofys, Mapping Carbon Pricing Initiatives: Developments and Prospects 2013 (Washington D.C.: Carbon Finance at the World Bank, 2013), 20, 41; Point Carbon [http://www.pointcarbon.com/], accessed in November 2013.

${ }^{36}$ Karen Holm Olsen, 'NAMAs for Sustainable Development', TERI Newsletter on NAMAs, Vol. 3 (4) and 4 (1), October-January 2013, 13-8.

${ }^{37}$ UNFCCC, Decision 1/CP.16, paragraph 48, document FCCC/CP/2010/7/Add.1.

${ }^{38}$ Sudhir Sharma and Denis Desgain, Understanding the Concept of Nationally Appropriate Mitigation Action (UNEP Risoe Centre, 2013), 11

Sharma and Desgain (Understanding, 11) also point out that a related key principle in the Convention is that 'economic and social development and poverty eradication are the first and overriding priorities of developing country parties' (Art. 4.7) and that actions by countries are in accordance with their 'respective capabilities and their social and economic conditions' (preambular section).

${ }^{40}$ UNFCCC, Decision 1/CP.16, paragraphs 61 and 62.

${ }^{41}$ Sharma and Desgain, Understanding, 11. Inclusion in national law, however, would render them nationally legally binding, as the authors note.

${ }^{42}$ UNFCCC, Decision 1/CP.16, paragraphs 52-6.
} 

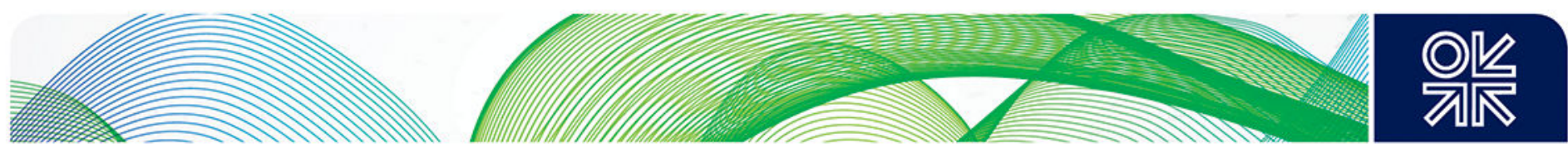

emerging, which would allow developing countries to monetise carbon offsets produced by the actions.

Analysing NAMAs submitted to the UNFCCC, Sharma and Desgain make a scope-based division into: (i) economy-wide goals (either an absolute emission reduction target, BAU emission deviation target, or an emission intensity target); (ii) sectoral goals; (iii) focal area NAMAs; (iv) measures; (v) specific actions (such as projects); and (vi) others (including development programmes). ${ }^{44}$ Only actions in the two first categories comprise numeric targets. Ecofys uses a simple division in its NAMA Database into strategies, policies and projects. ${ }^{45}$ The category of programmes can also be added to this list. ${ }^{46}$ Lütken et al., in turn, distinguish between policy and project NAMAs. ${ }^{47}$

By October 2013, 57 countries had communicated NAMAs to the UNFCCC, including five Arab countries (Algeria, Egypt, Jordan, Morocco and Tunisia). ${ }^{48}$ In contrast to the CDM, NAMAs have so far seen broader regional variation, including active participation by many states in the MENA region. Algeria's NAMA, for example, includes 'renewable energy management and development programmes', in addition to a notification of already taken measures in the areas of flaring reduction, promotion of low-carbon fossil fuel use and CCS. Of the ten high-income non-OECD, non-Annex I countries with a population of over one million (which include the six GCC states), ${ }^{49}$ only Singapore has submitted a NAMA, consisting of an emissions reduction target of 16 percent below BAU by $2020 .^{50}$ Sector-wise, a study from 2013 found that the energy supply sector accounted for around 40 percent of all supported NAMAs, followed by transport (19 percent), buildings (14 percent), waste (13 percent) and industry (11 percent). ${ }^{51}$ Interestingly, Mexico's national oil company Pemex is working on an oil and gas industry NAMA programme that focuses on gas flaring-related emissions reductions. ${ }^{52}$

Notably, given the flexible definition, there is great diversity in the scope and nature of actions, both submitted and potential. However, there is an understanding that numeric targets are more useful for setting tangible pathways and, as Sharma and Desgain note, 'a narrow scope may not have a significant impact on the economy-wide deviation from the BAU emissions' ${ }^{53}$ The international NAMA Partnership makes another useful functional characterisation of NAMAs communicated at the international level and those implemented at the national level. Whilst the former function as 'national contributions to global mitigation efforts as part of the UNFCCC', the latter can be understood as 'instruments to deliver planned social or economic benefits with less greenhouse gas emissions' ${ }^{54}$ It is in this last sense that the subsequent sections of this study will consider mitigation actions in the GCC states.

\footnotetext{
${ }^{43}$ Søren Lütken et al., Low Carbon Development Strategies: A Primer on Framing Nationally Appropriate Mitigation Actions (NAMAs) in Developing Countries (UNEP Risoe Centre, 2011), 7.

${ }^{44}$ Sharma and Desgain, Understanding, 13.

${ }^{45}$ Ecofys, 'What's included in the database?' (3 September 2013) [http://www.namadatabase.org/index.php/What\%27s_included_in_the_database\%3F], accessed in October 2013.

${ }^{46}$ Presentation in a Chatham House workshop: Approaching COP18: New Avenues for Enhancing Multilateral Action, Doha, 4 November 2012.

${ }^{47}$ Lütken et al., Low Carbon Development Strategies, 8-9.

${ }^{48}$ UNFCCC, document FCCC/SBI/2013/INF.12/Rev.2.

${ }^{49}$ List of high income non-OECD countries from: World Bank, 'World Development Indicators'

[http://databank.worldbank.org/], accessed in October 2013. Puerto Rico, Singapore, Trinidad and Tobago, and Uruguay.

${ }^{50}$ UNFCCC, document FCCC/SBI/2013/INF.12/Rev.2.

${ }^{51}$ Van Tilburg et al., Status Report on NAMAs, 11-2.

${ }^{52}$ Gustavo Sosa Iglesias, Methane Leakage and Flaring in Latin America and the Caribbean: Opportunities for Mitigation: Pemex's Practice', presentation in Intergovernmental Consultation on Near-Term Climate Protection and Clean Air for Latin America and the Caribbean, Bogotá, October-November 2012.

${ }^{53}$ Sharma and Desgain, Understanding, 14

${ }^{54}$ NAMA Wiki, 'What Are NAMAs' [http://namapartnership.wikispaces.com/What+are+NAMAs\%3F], accessed in October 2013.
} 


\subsubsection{Adaptation and Impacts of Response Measures}

Adaptation and mitigation are often seen as the two sides of 'the climate action mirror', one being contingent on the other. However, an important distinction to be made is the dependence of adaptation on mitigation: the more ambitious the mitigation actions, the less adaptation to climate change will be needed, but not vice versa. In the UNFCCC, adaptation has come to be seen as an important area of climate action, and a number of multilateral processes and institutions have been established under the Convention to provide support to developing countries, including the Adaptation Fund (est. 2001, which receives a share of all CDM project activity proceeds) and the Adaptation Committee (est. 2011, which provides capacity building, information and networking support). A key UNFCCC tool available for adaptation planning and action in developing countries, including the GCC, are the National Adaptation Plans (NAPs), which are technically and financially supported. ${ }^{55}$

As will be discussed more detail below (Section 3.1.4), the key physical impacts of climate change on the GCC states are expected in three areas: variations in temperature, precipitation and sea level rise. A special report on climate change by the International Energy Agency (IEA) outlines water stress and increases in surface temperatures as the key climate impacts affecting the Middle East. These, in turn, are expected to lead to increasing production costs and reduced cooling capacity in the oil and gas sector, which in turn will result in capacity limitations. ${ }^{56}$ Increased energy sector resilience will also be needed on offshore oil and gas rigs and in electricity grids. ${ }^{57}$ In the agricultural sector, an important indirect impact of climate change for the GCC states could come in the form of increased food insecurity and substantially higher food import bills, given the GCC states' high food import dependency, which is particularly high in the five smaller GCC states, but will be rising in Saudi Arabia too as it gradually phases out wheat, soya bean and fodder production subsidies due to exacerbating water scarcity. ${ }^{58}$ A draft of the IPCC's forthcoming fifth assessment report stated that global warming could reduce agricultural production by up to 2 percent each decade, until the end of the century. ${ }^{59}$

Apart from physical and socioeconomic impacts, a number of studies since the late 2000s have noted that climate change acts as a threat multiplier, ${ }^{60}$ or perhaps more precisely a challenge intensifier that makes existing socioeconomic and security challenges even more complicated or severe. In the Middle East these include tensions over scarce resources, climate-induced migration and, in extreme cases, poverty, unemployment and social instability. ${ }^{61}$ However, as argued by the author elsewhere, these are fairly unlikely scenarios in the near future for the GCC states (with the exception of ripple effects from possible climate change-intensified impacts of state failure in Yemen). ${ }^{62}$

An issue that has been actively promoted by GCC OPEC states on the UNFCCC negotiating agenda is that of response measures, or the adverse economic, social and environmental impacts on developing countries of the implementation of climate change response measures. The issue is included both in the Convention (art. 4.8 and 4.9) where countries dependent on oil exports is mentioned as a special group, and the Kyoto Protocol (2.3 and 3.14), by which Annex I states are required to strive to minimise the adverse impacts of response measures on other parties. Currently,

\footnotetext{
${ }^{55}$ UNFCCC, 'Adaptation' [http://unfccc.int/adaptation/items/4159.php], accessed in November and December 2013.

56 IEA, Redrawing, 92

${ }^{57}$ Fatih Birol, IEA, speaking for IISD-RS Video: \#2-12: UNFCCC - Bonn Climate Change Conference [http://www.iisd.ca/videos/climate/unfccc-sb38/\#video], accessed in November 2013.

${ }^{58}$ Luomi, The Gulf Monarchies and Climate Change, 60-1.

59 The draft was leaked to the press in November 2013. Justin Gillis, 'Climate Change Seen Posing Risk to Food Supplies', New York Times (1 November 2013).

Term coined by: CNA Corporation, National Security and the Threat of Climate Change (Washington D.C.: CNA Corporation, 2007).

${ }^{61}$ Oli Brown and Alec Crawford, Rising Tensions: Climate Change and the Risk of Violent Conflict in the Middle East (Winnipeg: International Institute for Sustainable Development, 2009), 10-8.

${ }^{62}$ Luomi, The Gulf Monarchies and Climate Change, 62.
} 

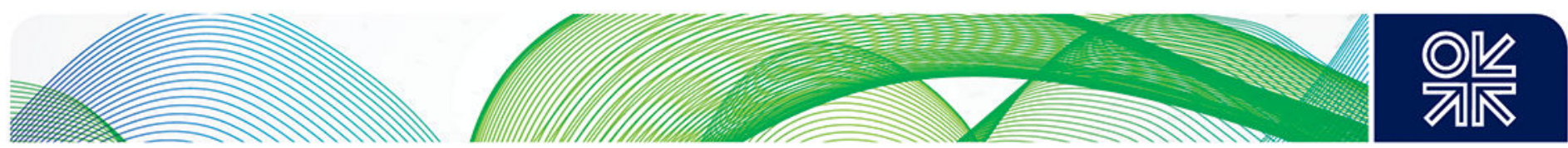

the issue is discussed under a dedicated forum and work programme. ${ }^{63}$ Stemming from the controversial nature of the issue and attention demanded for it by the GCC OPEC states, led by Saudi Arabia, these countries have gained a reputation of, at times, difficult participants in the international climate regime: literature on the role of OPEC and Saudi Arabia describes them as 'obstructionists' (states that join negotiations with the aim of preventing an agreement), ${ }^{64}$ and the countries' overall role in the regime, including in the IPCC (where Saudi Arabia, as recently as in September 2013, made a number of suggestions relating to the uncertainty of science and evidence on anthropogenic influence), ${ }^{65}$ has frustrated a number of parties and observers.

An emerging issue directly related to response measures is that of 'unburnable carbon', rooted in the idea of the global carbon budget (see Section 2.1.1), ${ }^{66}$ and with potentially broad-ranging future consequences for the GCC states, which are so highly dependent on fossil fuel revenues. Already in 2009, Meinshausen et al. suggested in an influential paper that less than half of proven economically recoverable fossil fuel reserves could be burned if the world were to have a 50 percent probability of limiting global warming to $2^{\circ} \mathrm{C} .{ }^{67} \mathrm{~A}$ more recent study by McGlade and Ekins suggests that even a widespread adoption of CCS would not significantly alter the share of recoverable oil that needs to stay unused. ${ }^{68}$

Despite the potentially significant implications of a near-term future world in which oil demand peaks and the GCC states would be unable to export a large share of their oil, unburnable carbon has so far not been part of energy debates in the region. ${ }^{69}$ On the contrary, indications of a belief in sustained future oil demand, possibly enabled by technological advances, are common: in 2008, King Abdullah of Saudi Arabia announced that he had ordered some new oil discoveries to be left for future generations. ${ }^{70}$ OPEC and Saudi officials continue to project that global oil demand will keep rising at least until 2035 and the world will rely on oil for at least another three decades. ${ }^{71}$ Meanwhile, other projections have gone as far as to suggest that a global oil demand peak might occur as soon as 2020. ${ }^{72}$ Nor has the issue been raised in the GCC states' positions vis-à-vis the climate negotiations. ${ }^{73}$ In the framework of the UNFCCC, compensation for oil left in the ground has so far only been proposed by Ecuador through its net-avoided emissions initiative, which was recently cancelled after a failure to raise funds at the level expected. ${ }^{74}$ At any rate, although the idea is only starting to gain global traction, incorporating oil-in-the-ground scenarios into the GCC states'

\footnotetext{
${ }^{63}$ Under the UNFCCC, vulnerability (and adaptation) to the negative impacts of response measures is usually regarded an issue related to mitigation. Given the importance attached to the latter by a number of countries, including many in the GCC, it response measures have generally been discussed as a separate topic.

E.g. Joanna Depledge, 'Striving for No: Saudi Arabia in the Climate Change Regime', Global Environmental Politics, 8 (2008), 9-11.

65 IISD-RS, 'Summary of the 12 Session of the Working Group I of the IPCC and $36^{\text {th }}$ Session of the IPCC: $23-26$ September 2013', Earth Negotiations Bulletin, Vol. 12, No. 581, 4, 6, 9.

${ }^{66}$ The Economist, 'Unburnable Fuel' (4 May 2013). The risk of unburnable carbon is slowly starting to figure on oil market analysts' radar, as these start seriously considering the impact of future climate policies and legislation and the likelihood of a peak oil demand. The author would like to thank the referee of this paper for suggesting a discussion on this issue.

${ }^{67}$ Malte Meinshausen et al., 'Greenhouse-gas Emission Targets for Limiting Global Warming to $2 \square^{\circ} \mathrm{C}$ ', Nature, 458 (2009), 1158-62.

${ }^{68}$ Christophe McGlade and Paul Ekins, 'Un-burnable Oil: An Examination of Oil Resource Utilisation in a Decarbonised Energy System', Energy Policy, 64 (2014), 102-12.

${ }^{69}$ It is difficult to ascertain whether leaving oil in the ground is simply not yet considered as a possible scenario, or whether the issue is discussed within a closed circle given the magnitude of socioeconomic changes involved and the lack of related economic incentives. The generally assumed unreliability of OPEC states' reserve estimates further complicates the picture.

${ }^{70}$ Reuters, 'Saudi King Says Keeping Some Oil Finds for Future', Reuters (13 April 2008).

1 Abdalla S. El-Badri, 'The Global Energy Outlook', opening remarks to the International Energy Week, Moscow, 28 October 2013 [www.opec.org/opec_web/en/2641.htm], accessed in January 2014; personal e-mail interview with Saudi Arabia's climate negotiating delegation, 30 December 2013.

Elizabeth Douglass, 'Investor Group Presses Oil Companies on “Unburnable Carbon”', Bloomberg (24 October 2013).

${ }^{73}$ These have rather focused on revenue losses resulting from reduced demand and related lower prices, and trade barriers.

${ }^{74}$ ITT-Yasuní Initiative. See e.g. Aurèlien Bernier, 'Ecuador's Plan Falters', Le Monde Diplomatique (July 2012).
} 

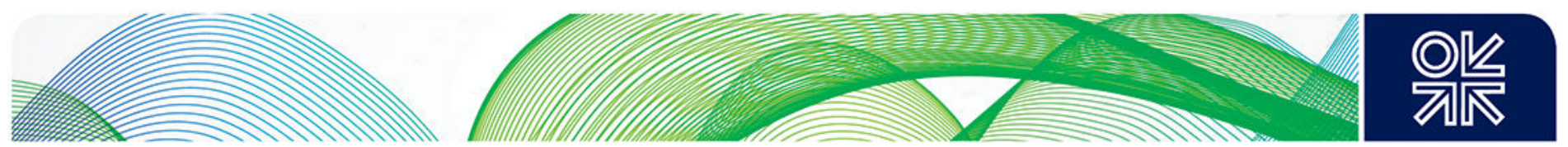

economic planning exercises will be crucial, given their high dependence on oil revenues and limited diversification options in the near term.

\subsubsection{Actions in the Area of Economic Diversification}

Fundamentally, a low-carbon transition for the GCC states requires not only a decarbonisation of the energy mix but also economic diversification. This latter challenge has long been an underlying theme of these states' positions in the UNFCCC. In the Doha climate conference in December 2012, four GCC states (Bahrain, Qatar, Saudi Arabia and the UAE) came forward with a proposal to present to the UNFCCC their economic diversification actions and plans with co-benefits in mitigation and adaptation to the impacts of climate change and response measures, in lieu of submitting NAMAs per se. These actions, which would be domestically funded and subjected to international measurement, reporting and verification (MRV), could, nevertheless, be registered as NAMAs. ${ }^{75}$ This approach created a way for the GCC states to submit NAMAs whilst feeling that their specific national circumstances ${ }^{76}$ were recognised. It can be argued that the economic diversification initiative also sets the four states on a trajectory to international pledges, and paves the way for their participation in the 2015 agreement.

When approved by COP $18,{ }^{77}$ the initiative was met with careful optimism. ${ }^{78}$ In late 2012 , many observers who had been hoping for a mitigation or financial pledges from the conference host Qatar and possibly other GCC states were quick to express their disappointment regarding the GCC states' 'ambiguous pledge to pledge. ${ }^{79}$ As the result of Saudi Arabia's reluctance to put forward actions at this stage and a drastically decreased domestic momentum for actions in Qatar owing to a disengaged Presidency, among other factors, announcements under the diversification umbrella had not yet been made by December 2013 and were expected by 2015 at the earliest. ${ }^{80}$ Nevertheless, signalling a serious interest in creating a framework for participation in pre-2020 action, even if under special conditions, Saudi Arabia suggested in May 2013 that the UNFCCC's web-based NAMA registry include an economic diversification entry. ${ }^{81}$ More recently, Saudi negotiators have suggested that the type of actions the country plans to include in the registry will be in the area of mitigation. ${ }^{82}$

\subsubsection{Low Emission Development Strategies}

A further relevant concept to explore is that of low emission (or carbon) development strategies (LEDS), sometimes referred to as low emission climate resilient development strategies (LECRDS). It was introduced by the COP in 2009, but finds its roots in the climate convention. The LEDS emerged from the increasing need to for intensified mitigation actions in developing countries and related information to guide financial and other support, given the insufficiency of mitigation in developed countries alone to prevent dangerous climate change. In this context, it has been described by Lütken et al. as 'a common but differentiated approach to meet the overall emissions reduction objectives'. ${ }^{83}$ In 2010, the COP decided that 'developed countries should develop low-carbon strategies or plans' and encouraged 'developing countries to develop low-carbon development strategies or plans in the context of sustainable development'. ${ }^{84}$ In 2011 and 2012, the COPs encouraged developing country Parties to develop LECRDS with financial and technical support from developed countries, taking into account national circumstances. ${ }^{85}$

\footnotetext{
${ }^{75}$ UNFCCC, document FCCC/CP/2012/MISC.2.

${ }^{76}$ As expressed in the submission: 'high economic reliance on hydrocarbon production' and 'the broader imperatives of sustainable development and economic diversification.' Ibid.

UNFCCC, Decision 24/CP.18, document FCCC/CP/2012/8/Add.3.

${ }^{78}$ Ed King, 'Qatar, Saudi Arabia, Bahrain \& UAE Make Mysterious Climate Pledge', RTCC (7 December 2012).

${ }^{79}$ E.g. Nick Mabey and Ed King, RTCC (7 and 13 December 2012).

${ }^{80}$ Personal communications and observations, UNFCCC meetings, 2012 and 2013.

81 Submission by Saudi Arabia, 'Views on the Fully Operational Prototype of NAMA Registry' (26 May 2013).

${ }^{82}$ Personal e-mail interview with Saudi Arabia's climate negotiation team members, 30 December 2013.

83 Lütken et al., Low Carbon Development Strategies, 5.

84 UNFCCC, Decision 1/CP.16, paragraphs 45 and 65.

${ }^{85}$ UNFCCC, Decision 2/CP.17, paragraph 38; Decision 1/CP.18, paragraph 22, document

FCCC/CP/2012/8/Add.1.
} 

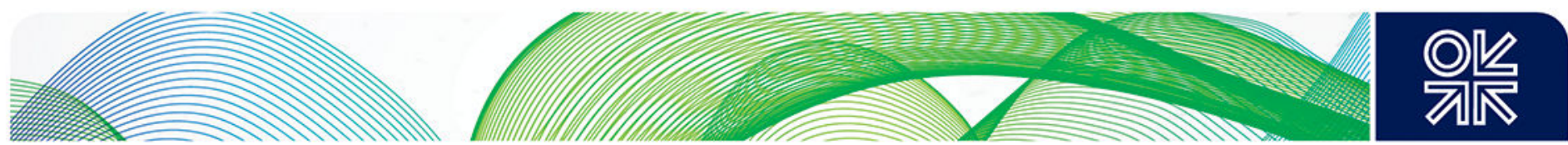

The term lacks a commonly agreed definition, but a UN portal describes them as 'forward-looking national economic development plans or strategies that encompass low-emission and/or climateresilient economic growth.' LEDS therefore include both dimensions of climate action: mitigation and adaptation/resilience. A development-centred approach, LEDS can be seen as 'addressing and integrating climate change with development objectives' ${ }^{86}$ They can also be described as 'nationallevel, country-led, and country-specific plans to promote economic growth and reduce long-term greenhouse gas (GHG) emission trajectories,' integrated in development planning, implemented, monitored, and revised as needed. ${ }^{87} \mathrm{~A}$ UN capacity-building centre sees a hierarchical relationship in development planning, in which national strategic development planning provides the framework for LEDS, which in turn provide one for policy and project NAMAs. ${ }^{88}$ It notes that a long-term determination of options for mitigation and adaptation in the context of national development enhances their effectiveness, and that this process will vary from one country to another, given different national circumstances. Focus is needed both on the process (government coordination and stakeholder involvement) and the result; the latter should materialise as a 'formulation of a sustainable pathway to achieve the established development goals' that includes: (i) national options and actions for low-carbon development (mid-term and long-term); (ii) sector-specific options and actions for GHG reductions; and (iii) a roadmap for implementation. LEDS gives the direction and NAMAs serve as the vehicles for its implementation. ${ }^{89}$

Related concepts include green economy and green growth (see also Section 4.3.3). LEDS can be considered a part of green growth strategies. ${ }^{90}$ Both incorporate the idea of decoupling economic growth from that of GHG emissions. A number of international agencies and donor governments provide support for developing LEDS, including the UNDP, UNEP, the World Bank, the European Union, and the United States. ${ }^{91}$ The LEDS Global Partnership's inventory lists around 70 multilateral LEDS support programmes globally. Whilst a number of North African and Levantine countries take advantage of these programmes, none of the Gulf countries appeared to do so at the time of writing. $^{92}$

\subsection{Domestic Mitigation Measures}

This section focuses on the domestic side of mitigation measures. According to a technical manual by the UNFCCC secretariat, 'a combination of technological solutions and policy measures will be necessary to achieve the low carbon economy required to stabilize the climate'. ${ }^{93}$ The IPCC lists a number of instruments available to countries to cut or curb emissions. ${ }^{94}$ These can be categorised into economic, regulatory and information instruments, and other actions, including voluntary agreements and technology (research and) development. Economic/market-based instruments mentioned in technical literature include: different types of taxes, cap-and-trade systems, fiscal and other incentives, and subsidies for alternative fuels and vehicles. ${ }^{95}$ Regulatory instruments include specifications, performance and emission standards, including building codes, reporting and targeting

\footnotetext{
${ }^{86}$ UNDESA, United Nations Sustainable Development Knowledge Platform, 'Low Carbon Development' [http://sustainabledevelopment.un.org/index.php?menu=1448], accessed in October 2013.

Orestes Anastasia, presentation: 'Foundations for Long-Term Sustainable Growth: Low Emission, Climate Resilient Development Strategies', The Asian and Pacific Regional Implementation Meeting on Rio + 20 Outcomes, Bangkok, 24 April 2013.

${ }^{88}$ Lütken et al., Low Carbon Development Strategies, 5.

${ }^{89}$ Ibid., 6-7.

90 Orestes Anastasia, presentation: 'Foundations for Long-Term Sustainable Growth: Low Emission, Climate Resilient Development Strategies,' The Asian and Pacific Regional Implementation Meeting on Rio + 20 Outcomes, Bangkok, 24 April 2013

91 UNDESA, United Nations Sustainable Development Knowledge Platform, 'Low Carbon Development' [http://sustainabledevelopment.un.org/index.php?menu=1448], accessed in October 2013

92 LEDS Global Partnership, 'LEDS Support Programs' [http://ledsgp.org/activities/all], accessed in October 2013

${ }^{93}$ UNFCCC, UNFCCC Resource Guide for Preparing National Communications of Non-Annex I Parties: Module

4: Measures to Mitigate Climate Change (Bonn: UNFCCC, 2008), 16.

${ }_{94}$ Gupta et al., 'Policies, Instruments and Co-operative Arrangements', 747

${ }^{95}$ UNFCCC, Module 4: Measures to Mitigate, 16-9.
} 

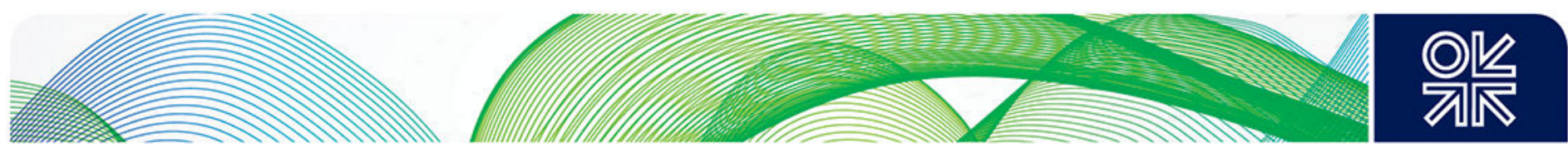

requirements, and regulation of utilities to encourage demand-side management. Information instruments, also known as persuasive measures, comprise education and awareness-raising, both in the form of short-term campaigns and long-term programmes and policies. Other actions listed in the literature include voluntary agreements, government-funded research and development (R\&D) and development and demonstration activities, and infrastructure investments. Hybrid instruments, as specified by the UNFCCC guide for national communications, include tradable emission permits and renewable portfolio standards. ${ }^{96}$

\subsubsection{Economy-wide Policies, Measures and Instruments}

Economy-wide mitigation tools include quantified economy-wide policies for curbing emission growth, such as emission or emission/energy intensity targets. Economy-wide policy instruments to curb emission growth include carbon taxes or markets. Currently, the GCC states do not employ any of these. In 2011, Dargin produced a detailed study on the optimal kind of mechanism, and recommended a pan-GCC cap-and-trade system, which would initially be voluntary but later become mandatory and would enable the GCC states to 'rationalize their energy usage for domestic power production, and conserve their oil and gas production for future generations'. ${ }^{77}$ Notably, a number of developing countries, including China, Brazil, Chile and Turkey are already either implementing or considering emissions trading schemes (ETS). ${ }^{98}$

\subsubsection{Energy Supply}

The energy supply sector is defined here as including industries involved in the extraction, transformation and transportation of energy, such as electric generation and oil production and refining. ${ }^{99}$ The IPCC's fourth assessment report presents related policy objectives in the areas of: energy efficiency, fuel switching, renewable energy, and carbon capture and storage. ${ }^{100}$ Economic policy instruments in these areas include: energy and GHG taxes; lower subsidies; fiscal incentives; tradable emission permits; and capital grants and feed-in-tariffs (for renewables). Regulatory instruments can include: minimum efficiency standards; power plant fuel portfolio standards (for switching); renewable energy targets; supportive transmission tariffs and access; and emission restrictions for major point source emitters (for CCS). The energy supply industries can also enter in voluntary agreements in the four policy areas, create information and education campaigns, in addition to engaging in technological (research and) development and deployment. Importantly, as the IPCC notes, many GHG reduction policies have multiple simultaneous aims, including market and subsidy reform. ${ }^{101}$ Emission reductions can also be the indirect result of policies with other primary goals, such as energy security, or broader structural changes in the economy. ${ }^{102}$

Beyond the IPCC's classification, it is perhaps useful to distinguish between demand and supply side policies and measures to reduce GHG emissions. Alam and Abdullatif present useful examples from the GCC context for the electricity and water sector (although they overlap in a number of areas with other sectors). ${ }^{103}$ According to the authors, supply side policies for electricity can include increasing the share of alternative energies (e.g. nuclear and solar energy) and deploying CCS, and supply side policies for the water sector include using newer technologies (e.g. reverse osmosis) and wastewater treatment and reuse. On the demand side, electricity-related measures include tariffs, building and

\footnotetext{
${ }^{96}$ Ibid.

97 Justin Dargin, The Development of a Gulf Carbon Platform: Mapping Out the Gulf Cooperation Council Carbon Exchange, Working Paper No 1. (Cambridge, MA: The Dubai Initiative, 2011), 6.

${ }^{98}$ International Carbon Action Partnership, 'Interactive ETS Map'

[http://icapcarbonaction.com/index.php?option=com_wrapper\&view=wrapper\&ltemid=147], accessed in October 2013.

${ }^{99}$ UNFCCC, Module 4: Measures to Mitigate, 16.

100 R.E.H. Sims et al., 'Energy supply', in Metz et al. (eds.) Climate Change 2007: Mitigation, 306.

101 Ibid., 305.

102 The fall of the Soviet Union is the prime example of the latter.

${ }^{103}$ Tanzeed Alam and Laila Abdullatif, 'The UAE Ecological Footprint', presentation on the UAE's work for the Living Planet Report 2010 (EWS-WWF, 2010).
} 

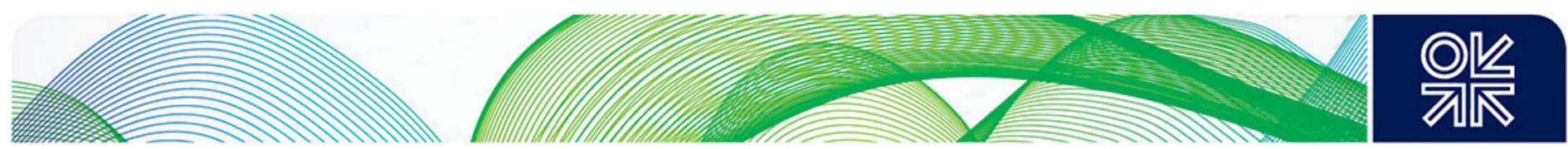

equipment standards, and use of electric vehicles, and water use-related measures include equipment standards, both indoor and outdoor.

\subsubsection{Buildings}

Residential and commercial buildings are an important source of GHG emissions given their (fossil fuel) energy use through heating/cooling, water (heating), household appliances, lighting and refrigeration, among other uses. If construction is included, the sector is the largest contributor to global GHG emissions and it holds the largest mitigation potential, in the form of a reduction in energy use of up to 60 percent by 2050 . However, barriers to change are also the highest in this sector and include lack of awareness, consumerism, fragmentation of the sector and perceived financial disincentives. ${ }^{104}$ Furthermore, some suggest that retrofitting of existing buildings may not be an economically interesting option in the Gulf region given the low quality of the older building stock. ${ }^{105}$

Technological mitigation measures mentioned by a UNFCCC manual include: energy-efficiency in cooling and heating systems, lighting, air-conditioners, appliances and motors; building insulation; solar energy applications for heating and cooling; and daylighting (use of natural light). ${ }^{106}$ Other measures include advanced applications of passive solar design (adapting buildings to site conditions), monitoring technologies for catalysing behavioural change, and community-based sustainable design (such as district cooling). ${ }^{107}$ The IPCC's fourth assessment report ranks 20 policy tools used in buildings, including regulatory, economic and financial instruments, voluntary action and support and information programmes, based on their emission reduction effectiveness and costeffectiveness. It concludes that, in terms of reductions in the amount of emissions, the most effective measures are appliance standards, building codes, demand-side management programmes, public benefit charges and eco-labelling, whereas the most cost-effective ones are investment subsidies. ${ }^{108}$

\subsubsection{Manufacturing and Construction}

Globally, five industries: iron and steel, chemicals, petroleum refining, pulp and paper, and cement, account for approximately 45 percent of industrial energy consumption. ${ }^{109}$ It is generally recognised that energy-intensive industries have the most potential for energy efficiency, and hence emission reductions. Mitigation measures in this sector include process changes aiming at emission reductions; material substitution and efficiency in product design; recycling of materials; efficiency in lighting, motors, process controls and space cooling. Notably, regulation, according to the UNFCCC, is the most direct method for behavioural change in industry. Equipment efficiency standards that exclude sub-standard equipment from the market can also bring important reductions. ${ }^{110}$ The IPCC report from 2007 focuses on mitigation technologies, including in the areas of energy and material efficiency, fuel switching, power recovery, deployment of renewables, feedstock change, and $\mathrm{CO}_{2}$ sequestration. Whilst many technologies are industry-specific, some are sector-wide, such as energy management systems for energy efficiency, cogeneration for power, use of renewables, use of recycled inputs, and $\mathrm{CO}_{2}$ separation from flue gas. ${ }^{111}$ Instruments available for emission reductions in industry include voluntary agreements and economic instruments (such as taxes or tax reductions, emission trading schemes, regulation of non- $\mathrm{CO}_{2}$ gases, and project participation in Kyoto's CDM). ${ }^{112}$

\footnotetext{
${ }^{104}$ Wynn Chi-Nguyen Cam, Technologies for Climate Change Mitigation: Building Sector, TNA Guidebook Series (UNEP Risoe Centre, 2012), 2, 11-3.

${ }^{105}$ Giacomo Luciani, Energy Efficiency Policies in the MENA Countries (2012), 9-10.

106 UNFCCC, Module 4: Measures to Mitigate, 17.

107 Chi-Nguyen Cam, Technologies for Mitigation, 23-6.

${ }^{108}$ Also, labelling, voluntary programmes and information instruments can also yield results if combined with other instruments and measures. M. Levine et al., 'Residential and commercial buildings' in Metz et al. (eds.) Climate Change 2007: Mitigation, 431.

${ }^{109}$ UNFCCC, Module 4: Measures to Mitigate, 17.

110 lbid., 16-9.

111 L. Bernstein et al., 'Industry', in Metz et al. (eds.), Climate Change 2007: Mitigation, 454-5.

112 Ibid., 478-82.
} 


\subsubsection{Transport}

In the transport sector, the scope for global emission reductions is still wide and broadening, given that petroleum is expected to remain the dominant source fuel for the foreseeable future, which together with increasing volumes translates into a rising emissions trajectory. According to the IPCC, improvements in current vehicle technologies bear the biggest potential for curbing sectoral emissions globally. Potential also exists in advanced technologies, such as battery electric vehicles, and the use of alternative fuels, including compressed natural gas, biofuels and electricity. ${ }^{113}$ In addition to fuel efficiency achieved through vehicle and engine design changes on the technology improvement side, an UNFCCC guide lists the expansion of public transport infrastructure and land-use planning for dense settlements. ${ }^{114}$ Literature also mentions reducing overall travel, and support to walking and cycling. ${ }^{115}$ Freight, rail, air and water transport are also areas where mitigation policies and measures can be applied.

\subsubsection{Fugitive Emissions}

Given the important share of fugitive emissions of the GCC states' emissions, these are treated here as a separate category. Fugitive emissions - principally from methane, but also carbon dioxide and, in minor quantities, nitrous oxide $\left(\mathrm{N}_{2} \mathrm{O}\right.$, from flaring) - are the result of equipment leaks, process flaring and venting, evaporation losses and accidental discharges. In the GCC, fugitive emissions are produced by the oil and gas industry, in various phases: exploration, production, processing, refining, transmission, storage and distribution. ${ }^{116}$ Flaring reductions can result in important economic benefits: the Kuwait Oil Company has reported US $\$ 2.75 \mathrm{bn}$ in gains from flaring cuts since $2007 .{ }^{117}$ Importantly, according to experts, data is often poor and incomplete, and there has been 'substantial uncertainty' regarding available data for Middle Eastern OPEC member states. ${ }^{118}$

Literature on mitigation in this area focuses on methane, which given both its abundance (14 percent of global GHG emissions) and its global warming potential (21 times greater than $\mathrm{CO}_{2}$ ), is the second most important source of anthropogenic climate forcing. ${ }^{119}$ The international public-private Global Methane Initiative (est. 2004) promotes methane emission reductions in oil and gas systems as a cost-effective mitigation strategy, with benefits for energy security, economic growth, air quality and worker safety. Mitigation measures promoted by the initiative include technical fixes, such as new and retrofitted equipment and maintenance and operational improvements. ${ }^{120}$ Saudi Arabia has recently joined the initiative. ${ }^{121}$ The World Bank Global Gas Flaring Reduction Partnership (GGFR, est. 2002) provides a collaborative framework for its members to increase the use of associated gas by reducing flaring and venting (including through CDM projects), and a voluntary standard that aims at significant reductions in a time frame of 5-10 years. ${ }^{122}$ Of the GCC states, Qatar (Qatar Petroleum) and Kuwait (Kuwait Oil Company) are members of the GGFR. A more recent Climate and Clean Air Coalition (CCAC), which so far has no GCC members, seeks to reduce short-lived climate pollutants, including methane, black carbon and HFCs, in order to slow down global warming by $2050 .{ }^{123}$

\footnotetext{
${ }^{13}$ S. Kahn Ribeiro et al., 'Transport and Infrastructure', in Metz et al. (eds.), Climate Change 2007: Mitigation, 335-6.

114 UNFCCC, Module 4: Measures to Mitigate, 16-7.

${ }^{115}$ Robert Salter et al. (eds.), Technologies for Climate Change Mitigation: Transport Sector, TNA Guidebook (UNEP Risoe Centre, 2011).

UNFCCC Consultative Group of Experts, 'CGE Training Materials: National Greenhouse Gas Inventories: Energy Sector - Fugitive Emissions', presentation, 2 April 2012.

Edmund O’Sullivan, 'Gas Flaring Efficiencies Save Kuwait Oil Company \$2.75bn', MEED (2 June 2013).

${ }^{18}$ David Picard, 'Fugitive Emissions from Oil and Natural Gas Activities', background paper for Good Practice Guidance and Uncertainty Management in National Greenhouse Gas Inventories (IPCC, 2000).

${ }^{9}$ Global Methane Initiative, Oil and Gas System Methane: Reducing Emissions, Advanced Recovery and Use, brochure (September 2011), 1.

${ }^{120}$ lbid., 1-2.

121 Minister Ali Al-Naimi's speech in the COP19/CMP9 joint high-level segment, Warsaw, 20 November 2013.

122 Global Gas Flaring Reduction, Global Gas Flaring Reduction Partnership (GGFR): Improving Energy

Efficiency \& Mitigating Impact on Climate Change (World Bank, 2011).

${ }^{123}$ Climate and Clean Air Coalition, 'Short-Lived Climate Pollutants'

[http://www.unep.org/ccac/ShortLivedClimatePollutants/tabid/101650/Default.aspx], accessed in October 2013.
} 


\subsubsection{Other Sectors and Consumer Behaviour}

Other major sources of global GHG emissions are waste, agriculture and forestry. In the GCC, the significance of forestry and land use changes for GCC emissions is not significant. Of the six states, only Saudi Arabia has more significant absolute emissions in the two other sectors. In agriculture, according to the IPCC, the main mitigation measures are improved crop and grazing land management and soil restoration. ${ }^{124}$ Waste sector emissions are contingent on a number of factors, ranging from policies encouraging waste minimisation, recycling and reuse, and energy recovery from waste. ${ }^{125}$ Consequently, sectoral policy measures can include waste prevention at source, recycling, composting, waste-to-energy incineration, and capturing methane from landfills and wastewater. ${ }^{126}$

Finally, distinct from the economic sectors, consumer behaviour merits a separate examination given that it runs across various sectors, including buildings, transport and waste. Behavioural change holds important mitigation potential in all societies globally: for example, a study on the European Union (EU), often considered to be at the forefront of global mitigation action, found an emission reduction potential of up to $600 \mathrm{MtCO}_{2} \mathrm{e}$ (more than Saudi Arabia's total annual GHG emissions) by 2020 resulting from behavioural changes ranging from reducing space heating by $1^{\circ} \mathrm{C}$ to shifting to a vegetarian diet and changes in driving styles and vehicles. ${ }^{127}$ Barriers to behavioural change relate to social and cultural norms (e.g. eating meat) and knowledge (e.g. lack of awareness of personal energy consumption). The latter in particular, according to the EU study, can be overcome through communication, voluntary agreements, and regulatory instruments (such as labelling). Habits, in turn, can be changed with economic instruments and school-based interventions. ${ }^{128}$

\subsection{Resilience to Climate Change and Response Measures}

Whilst resilience to climate change and that to response measures are both systemic qualities, generally different solutions apply for strengthening each. In the GCC context, the most manifest future challenges relating to the former are water and food insecurity, whereas most of these states agree that the key tool to increasing resilience to the impacts of response measures is economic diversification.

Adaptation strategies to climatic and natural circumstances have long been implemented by societies worldwide. Despite the GCC states' decades-long experience in adaptation to an extreme climate and water scarcity, further adaptation challenges are ahead even for the GCC states. The IPCC stresses that additional measures will be required worldwide in the coming decades regardless of the scale of mitigation. ${ }^{129}$ Furthermore, in a changing climate, already existing stresses and tensions, such as food insecurity, can further exacerbate states' vulnerability. The IPCC lists a number of low-cost (or highbenefit) sectoral adaptation measures, which include, in the agricultural sector: adjustments in planting patterns (including crops) and sustainable land management and, in the water sector: storage and conservation, re-use, desalination, and efficient use. As adaptation options to sea level rise, the IPCC proposes relocation, seawalls and storm surge barriers, protection of existing natural barriers, and using wetlands as buffers. In the energy sector, adaptation measures can include strengthening of overhead transmission infrastructure and using underground cabling, deployment of renewable energy, and reducing dependence on single energy sources. ${ }^{130}$

Existing literature on the MENA region recommends adaptation actions in several areas. In coastal areas, El-Raey recommends detailed vulnerability assessments, institutionalised risk reduction systems, strong monitoring systems, models for estimating the impact of climate change, integrated

\footnotetext{
${ }^{124}$ P. Smith et al., 'Agriculture', in Metz et al. (eds.), Climate Change 2007: Mitigation, 499.

125 J. Bogner et al., 'Waste Management', in Metz et al. (eds.), Climate Change 2007: Mitigation, 607.

${ }^{126}$ UNFCCC, Module 4: Measures to Mitigate, 19.

127 Jasper Faber et al., Behavioural Climate Change Mitigation Options and Their Appropriate Inclusion in Quantitative Longer Term Policy Scenarios, Delft Report (Delft: CE Delft, 2012), 55.

${ }^{128}$ Ibid.

${ }^{129}$ IPCC, 'Adaptation and Mitigation Options' [http://www.ipcc.ch/publications_and_data/ar4/syr/en/spms4.html], accessed in November 2013.

${ }^{30}$ Ibid.
} 

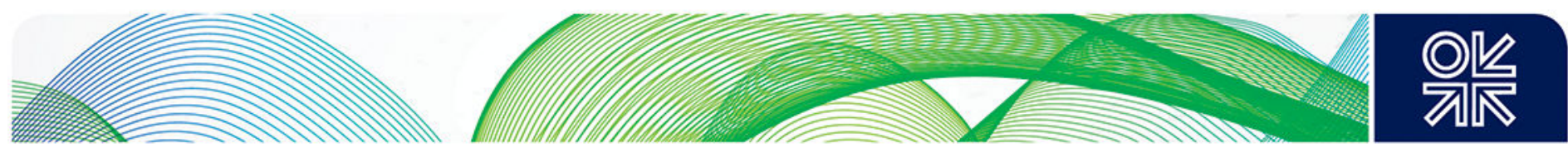

coastal management systems and proactive planning approaches, decision-makers' awareness, and job opportunities for vulnerable groups. ${ }^{131}$ For agriculture, Abou Hadid proposes altering management of cropping systems to projected changes, infrastructure development and institutional capacitybuilding, measures inspired by traditional knowledge, and technology and knowledge transfer. ${ }^{132}$ In relation to water use and security, El-Din El-Quosy mentions improved efficiency, including in agriculture, technology transfer, awareness-raising and expansion of storage facilities. ${ }^{133}$ In the area of infrastructure resilience Assaf mentions transportation (integrated transportation and land-use planning), coastal protection works (integrated coastal zone management), water supply and wastewater systems (integrated water supply/demand management, aquifer recharge and wastewater treatment), and energy generation and supply systems (improved power plant efficiency, demand management, decentralization of power generation, storm planning, and strategic fuel reserves). ${ }^{134}$ Other areas where regional adaptation measures will be required are human health and ecosystems and biodiversity.

\subsection{Other Climate Change-Related Measures}

There is general understanding in the international climate regime that national mitigation and adaptation activities in developing countries require so-called means of implementation: finance, technology and capacity-building. These can be nationally generated or provided by developed (or even other developing) countries. In terms of financing under the UNFCCC, the GCC states are eligible for the same types of support as other countries classified as developing countries, including financial support for NAMAs registered for support. In practice, however, partly attributable to their wealth, finance flows towards the GCC states have materialised through two routes only: capacity support (including national communications) and through the CDM. The GCC states have also provided some climate financing to other developing countries, despite strong reluctance, at least until 2012, to these appearing as contributing multilateral climate finance (since this is something considered as an exclusive obligation of developed countries) for fear of creating a peer group precedent. $^{135}$

Technology transfer is considered by the GCC states as an important area for international support for domestic climate actions. Some are already pursuing technology transfer 'unilaterally', through state-funded investment vehicles, such as Abu Dhabi's Masdar Initiative. The IPCC notes that for effective technology development, innovation and deployment, government support through financing, standards, and creation of markets, as well as other enabling conditions (institutional, policy, legal and regulatory frameworks), is important. The fact that public benefits of $R \& D$ investments are higher than those captured by the private sector justifies government support. ${ }^{136}$ Since the mid- to late 2000 s, three GCC states in particular (the UAE, Qatar and Saudi Arabia) have become increasingly active in the area of environmentally sustainable technology development and R\&D.

UNFCCC-specific capacity-building spans all the above-mentioned areas and includes research and systematic observation. It can be focused on building GHG inventories, or preparing vulnerability and adaptation or mitigation assessments. The national communications to the UNFCCC of Bahrain, Kuwait and Saudi Arabia, for example, have been prepared with technical and policy support from the UNEP and UNDP and funded by the Global Environment Facility (GEF). ${ }^{137}$ The UNDP also provides technical and financial support for developing countries for preparing 'Green LECRDS', and the World

\footnotetext{
${ }^{131}$ Mohamed El-Raey, 'Coastal Areas', in Mostafa K. Tolba and Najib W. Saab (eds.), Arab Environment: Climate Change. Impact of Climate Change on Arab Countries. 2009 Report of the Arab Forum for Environment and Development (Beirut: AFED, 2009), 60-1.

${ }^{132}$ Ayman F. Abou Hadid, 'Food Production', in Tolba and Saab (eds.), Arab Environment: Climate Change, 70133

133 Dia El-Din El-Quosy, 'Fresh Water', in Tolba and Saab (eds.), Arab Environment: Climate Change, 84-5.

${ }^{134}$ Hamed Assaf, 'Infrastructure', in Tolba and Saab (eds.), Arab Environment: Climate Change, 114-9.

${ }^{135}$ Personal observations, autumn 2012.

${ }^{136}$ T. Barker et al., 'Summary for Policymakers', in Metz et al. (eds.), Climate Change 2007: Mitigation , 20-1.

${ }^{137}$ National Communications Support Programme website [http://ncsp.undp.org/], accessed in December 2013.
} 

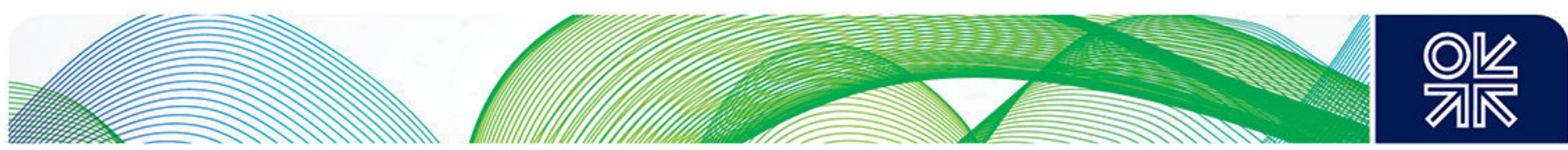

Bank has a programme for supporting the development of LEDS and NAMAs. ${ }^{138}$ Capacity can also be acquired through participation in regional and international cooperative arrangements. In the broadest sense, capacity-building comprises all societal aspects relating to climate action, from human to institutional capacity, and can be defined as comprising knowledge, tools, public support, scientific expertise and political know-how. ${ }^{139}$

\footnotetext{
138 UNDP, 'Green, Low-emission and Climate Resilient Development Strategies'

[http://www.undp.org/content/undp/en/home/ourwork/environmentandenergy/focus_areas/climate_strategies.html ]; World Bank, 'Climate Change' [http://wbi.worldbank.org/wbi/about/topics/climate-change], both accessed in December 2013.

139 UNFCCC, 'Capacity-Building: Background'

[http://unfccc.int/cooperation_and_support/capacity_building/items/7061.php], accessed in December 2013.
} 


\section{Context and Status of Climate Policy in the GCC}

Despite the active participation of the GCC (in particular Saudi Arabia) in the UNFCCC, the six states have shown varying degrees of interest in registering their actions at the international level. With the perhaps most hesitant one in the group, Saudi Arabia, calling the shots, ${ }^{140}$ the GCC states seem to have opted for a wait-and-see approach in the UNFCCC, with no NAMAs or economic diversification initiatives announced by the end of 2013. In this period of reflection, whilst countries are starting to prepare domestically for announcing their contributions to the 2015 agreement, a pragmatic, bottomup approach to exploring the potential of domestic mitigation (as well as adaptation and diversification) actions in the GCC is both timely and needed.

The first part of this section provides a contextualisation for climate action in the GCC states, including an examination of national circumstances, GHG emissions profiles, national capabilities and vulnerabilities, and the institutional context. The subsequent parts provide sector-based examinations of existing climate-relevant actions and plans in the three key GCC states that have been the most active in terms of new initiatives and announcements in this area in the past years (namely Qatar, Saudi Arabia and the UAE).

\subsection{Climate Policy Context}

An examination of what the GCC states understand as their national circumstances is required for determining the potential areas for synergies and further action in the context of the countries' specific conditions and development priorities. Furthermore, any climate policy needs to be based on factual data on present and expected future emissions. Finally, the capabilities of the six states to take action and their vulnerabilities to climate change and international climate action should also be taken into account, as they will also shed light on national strengths and weaknesses, on the one hand, and the areas where existing experience and technologies can be leveraged and areas where support is still needed, on the other.

\subsubsection{National Circumstances}

The UNFCCC guidelines for the preparation of national communications (NC) state that non-Annex I countries should include a description of the countries' 'national and regional development priorities, objectives and circumstances, on the basis of which they will address climate change and its adverse impacts'. This can include relevant information on geography, climate and economy, and on 'specific needs and concerns' relating to the impacts of climate change and response measures. ${ }^{141}$ Of the six GCC states, five (all but Oman) have submitted one or more NC to the UNFCCC. ${ }^{142}$ The mapping of national circumstances, as reported by the countries themselves, draws from the most recent communication of each of the five states, published in 2011-2013. The national circumstances described in the NCs examined can be grouped into four broad categories: physical circumstances (geography and climate); social circumstances (demography, human development, governance, health, education); environmental quality (biodiversity, air quality, water resources, waste); and economic structure (resource endowments, sectors, strategies and plans, including diversification). ${ }^{143}$

\footnotetext{
140 Personal communications, December 2012, June 2013 and November 2013.

${ }^{141}$ UNFCCC, Decision 17/CP.8, FCCC/CP/2002/7/Add.2.

${ }^{142}$ Received by the UNFCCC secretariat: Bahrain: 2005 and 2012; Kuwait: 2012; Qatar: 2011; Saudi: 2005 and 2011; and UAE: 2007, 2011 and 2013.

This section is based on: Kingdom of Bahrain Public Commission for the Protection of Marine Resources, Environment and Wildlife, Bahrain's Second National Communication UNFCCC (2012); State of Kuwait Environment Public Authority, Kuwait's Initial National Communications under the UNFCCC (2012); State of Qatar Ministry of Environment, Initial National Communication to the UNFCCC (2011); Kingdom of Saudi Arabia, Second National Communication (2011); UAE Ministry of Energy, $3^{\text {rd }}$ National Communication under the UNFCCC (2012).
} 

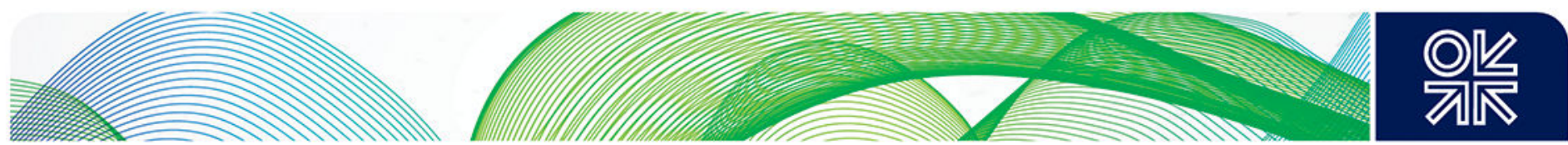

The five states describe their geography as low-lying, in coastal areas, with land expansion through reclamation as an additional feature. Two include themselves as small island states (Bahrain and Qatar). The GCC states' climate overall is characterised as hyper-arid or arid, and hot (hot summers and relatively mild winters), with high evapotranspiration rates. Increases in average annual temperatures over the past four to six decades have been recorded, at least in Bahrain and Qatar. Present rainfall levels are extremely low but there is less clarity on rainfall patterns over previous decades. Strong winds (shamal) occur in both winter and summertime (Qatar), and associated dust storms are frequent in the summer (Kuwait).

Regarding social factors, the GCC populations have experienced rapid growth over the 2000s, with large shares of expatriates, and improving scores in the UN human development index (Qatar). With the exception of Saudi Arabia (28 million), the GCC populations are small. Populations in many states are dense, overwhelmingly urban, and mostly concentrated in coastal zones. Health of the populations is good, and education standards are described as relatively high (Bahrain). Unlike the other states, the UAE is a federal system.

Environmental policy is largely focused on biodiversity conservation. Terrestrial and marine biodiversity is described as rich (Kuwait) and unique (Qatar), and partly under threat. Problems in air quality include peaks in $\mathrm{NO}_{\mathrm{x}}$ (nitrogen oxides) and unhealthy levels of $\mathrm{PM}_{10}$ (inhalable particulate matter) and $\mathrm{O}_{3}$ (ozone) (Qatar). Groundwater resources are low and depleting, and recharge programmes exist in some countries. Resulting from socioeconomic development, solid waste and wastewater quantities have increased substantially over the past decades.

The economies are rich (albeit with variation) and small to mid-size (except Saudi Arabia, a G20 member), and have some of the world's largest oil and natural gas reserves. They are highly dependent on oil and natural gas export revenues, which constitute a large share of their GDP, export revenues and government income. Capitalising on their oil and natural gas wealth the GCC economies have experienced rapid economic growth over the past decades, in particular over the past decade. A large share of oil and gas is exported to Asian markets. GCC governments report to have made strides in economic diversification, but some note that this is masked by the rises in oil and gas prices over the past decade (Qatar). The UAE describes its economy as well diversified. The manufacturing sector in particular is of importance, with major sub-sectors including petroleum refining, chemicals, fertilisers, metals and construction materials. Economic diversification measures include: expansion of natural gas export and petrochemical industries, and other energy intensive industries; investments and reform in education; and expansion in the sectors of aviation and maritime transport (Qatar). Road and other transport infrastructure are in good condition, and expanding, with Dubai serving as a major regional transportation hub. Given the climatic conditions, agricultural potential in the GCC states is limited or extremely limited.

Some aspects of the energy and water supply sector are mentioned: electricity is produced primarily from natural gas (except in Kuwait and Saudi Arabia), with oil serving as a secondary source. Given their water scarcity (low precipitation and depleting groundwater resources) and wealth, GCC states rely to a large extent on desalination for potable water (produced mostly through cogeneration with electricity). Water use per capita is amongst the highest in the world, and total demand for water is rising.

\subsubsection{GHG Emission Profiles}

As noted previously, parties to the UNFCCC are also required to submit an emissions inventory as part of their national communications. Emission inventories have been produced, as follows: Bahrain: 1994 and 2000; Kuwait: 1994; Qatar: 2007; Saudi Arabia: 1990 and 2000; and the UAE: 1994, 2000, 
2005. Given the lack of more recent emissions data, the analysis in this respect relies on data compiled by the World Resources Institute (WRI), the International Energy Agency (IEA), and the US Energy Information Administration (US EIA). ${ }^{144}$ In historical terms, the cumulative $\mathrm{CO}_{2}$ emissions of each of the six GCC states from 1850 to 2007 represent only $0.04-0.58$ percent of the world total. ${ }^{145}$ In present terms too, the GCC states are small emitters in terms of total current GHG emissions, with emissions of the five smaller states adding up to roughly 1.5 percent of total global emissions, as shown in Table 1. According to the WRI, in 2010, Saudi Arabia (1.2 percent) ranked as the world's $17^{\text {th }}$ highest emitter, ahead of a number of countries with substantially larger populations, such as Italy, Spain and Turkey. ${ }^{16}$

Table 1: Greenhouse gas emissions in the GCC states. ${ }^{147}$

\begin{tabular}{|c|c|c|c|c|c|c|}
\hline $\begin{array}{l}\text { Emissions } \\
(2000) \\
\mathrm{MtCO}_{2} \mathrm{e} \\
\text { self- } \\
\text { reported }\end{array}$ & $\begin{array}{c}\text { Emissions } \\
(2000), \\
\mathrm{MtCO}_{2} \mathrm{e} \\
\text { per WRI }\end{array}$ & $\begin{array}{c}\text { Emissions } \\
(2010), \\
\mathrm{MtCO}_{2} \mathrm{e} \\
\text { per WRI }\end{array}$ & $\begin{array}{l}\text { Share of } \\
\text { global } \\
\text { total } \\
(2010) \\
\text { per WRI }\end{array}$ & $\begin{array}{c}\text { Per capita } \\
(2010), \mathrm{tCO}_{2} \mathrm{e} \\
\text { (global rank) } \\
\text { per WRI }\end{array}$ & $\begin{array}{c}\text { Emission } \\
\text { growth } \\
\text { / TPES growth, } \\
\text { CAGR 2000-10 }\end{array}$ & $\begin{array}{l}\text { Population } \\
\text { growth } \\
\text { / GDP growth, } \\
\text { CAGR 2000-10 }\end{array}$ \\
\hline \multicolumn{7}{|l|}{ Bahrain } \\
\hline 22.37 & 17.36 & 34.81 & $0.1 \%$ & $27.58(14)$ & $7.2 \% / 5.3 \%$ & $6.5 \% / 5.9 \%$ \\
\hline \multicolumn{7}{|l|}{ Kuwait } \\
\hline $\mathrm{n} / \mathrm{a}$ & 138.88 & 196.50 & $0.4 \%$ & $71.80(1)$ & $3.5 \% / 5.9 \%$ & $4.6 \% / 4.7 \%$ \\
\hline \multicolumn{7}{|l|}{ Oman } \\
\hline $\mathrm{n} / \mathrm{a}$ & 63.04 & 90.41 & $0.2 \%$ & 32.49 (11) & $3.7 \% / 9.5 \%$ & $2.5 \% / 4.9 \%$ \\
\hline \multicolumn{7}{|l|}{ Qatar } \\
\hline $\mathrm{n} / \mathrm{a}$ & 26.97 & 74.69 & $0.2 \%$ & $42.46(6)$ & $10.7 \% / 8.0 \%$ & $11.4 \% / 12.4 \%$ \\
\hline \multicolumn{7}{|l|}{ Saudi Arabia } \\
\hline $283.31^{i}$ & 296.73 & 542.10 & $1.2 \%$ & $19.75(22)$ & $6.2 \% / 5.3 \%$ & $3.1 \% / 5.4 \%$ \\
\hline \multicolumn{7}{|l|}{ UAE } \\
\hline 119,89 & 110.56 & 256.27 & $0.6 \%$ & $34.12(9)$ & $8.8 \% / 6.2 \%$ & $10.8 \% / 3.9 \%$ \\
\hline \multicolumn{7}{|l|}{ World } \\
\hline $\mathrm{n} / \mathrm{a}$ & $38,224.71$ & $47,182.61$ & $100 \%$ & $6.84(-)$ & $2.3 \% / 2.3 \%$ & $1.2 \% / \mathrm{n} / \mathrm{a}$ \\
\hline
\end{tabular}

i) Includes only $\mathrm{CO} 2, \mathrm{CH} 4, \mathrm{~N} 2 \mathrm{O}$ and LUCF.

The GCC states rank amongst the world's highest per capita emitters, with Kuwait as the $1^{\text {st }}$ and Qatar at $6^{\text {th }}$ in 2010. GCC per capita emissions, overall, have remained roughly at the same levels over the past ten years despite the important growth in population and in the economy. ${ }^{148}$ The high emission levels stem from a number of factors, including reliance on fossil fuels, energy intensive industries, hot climate, dependence on desalination, high household consumption of utilities, and overall system and usage inefficiencies, partly stemming from the low user prices of utilities and fuels.

Average annual emission growth over the 2000s was over the global average in all GCC states, but it was especially high in Bahrain (7.2 percent), Qatar (10.7 percent), Saudi Arabia (6.2 percent) and the

\footnotetext{
${ }^{144} \mathrm{WRI}$ is an internationally respected source of emissions data. It has recently launched the second edition of its Climate Analysis Indicators Tool, with data until 2010. The IEA compiles broad annual datasets on energy balances in OECD and non-OECD countries. Data for this study was available until 2010. The US EIA has a comprehensive data set for carbon intensity, until 2011

${ }^{145}$ WRI, CAIT 8.0 (Washington D.C., 2011).

${ }_{146}$ WRI, 'Climate Analysis Indicators Tool (CAIT 2.0)' [cait2.wri.org/], accessed in October 2013.

${ }^{147}$ Emissions: UNFCCC national communications; WRI, 'CAIT 2.0', accessed in October 2013. Data includes all GHGs and land use change and forestry (LUCF). TPES: IEA, Energy Balances of Non-OECD Countries, 2012 edition (Paris: OECD/IEA, 2012), II, 346. Population and GDP: World Bank, 'World Development Indicators', accessed in October 2013. Constant local currencies used for GDP growth calculations.

${ }^{148}$ WRI, 'CAIT 2.0', accessed in October 2013. Per capita emissions in $2000\left(\mathrm{tCO}_{2} \mathrm{e}\right)$, including LUCF: Bahrain: 27.21; Kuwait; 71.56; Oman: 27.84; Qatar: 45.63; Saudi Arabia: 14.8; and the UAE: 36.45.
} 

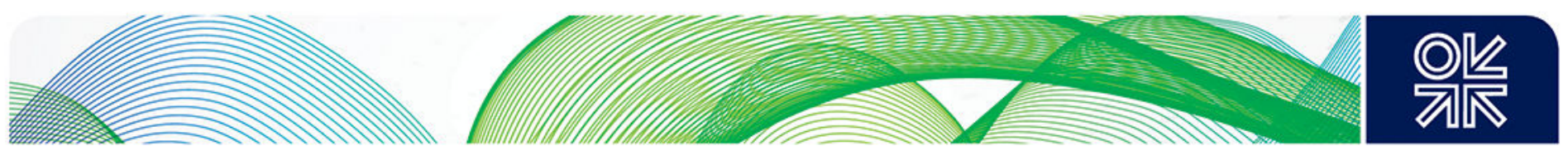

UAE (8.8 percent), as shown in Table 1. In these four states, emissions also grew faster than total primary energy supply (TPES), resulting in a rise in emission intensity. Similarly to emission growth and TPES growth, comparing emission growth to population and economic growth does not result in consistent patterns: in 2000-2010, emissions grew faster than the population in Bahrain, Oman and Saudi Arabia, whereas emissions grew faster than the economy in Bahrain, Saudi Arabia and the UAE. Figure 1 demonstrates the GCC states' total emission growth in 2000-2010, in a graphical form.

Figure 1: Total GHG emissions in $\mathrm{MtCO}_{2} \mathrm{e}$ in the GCC states, 2000-2010. ${ }^{149}$

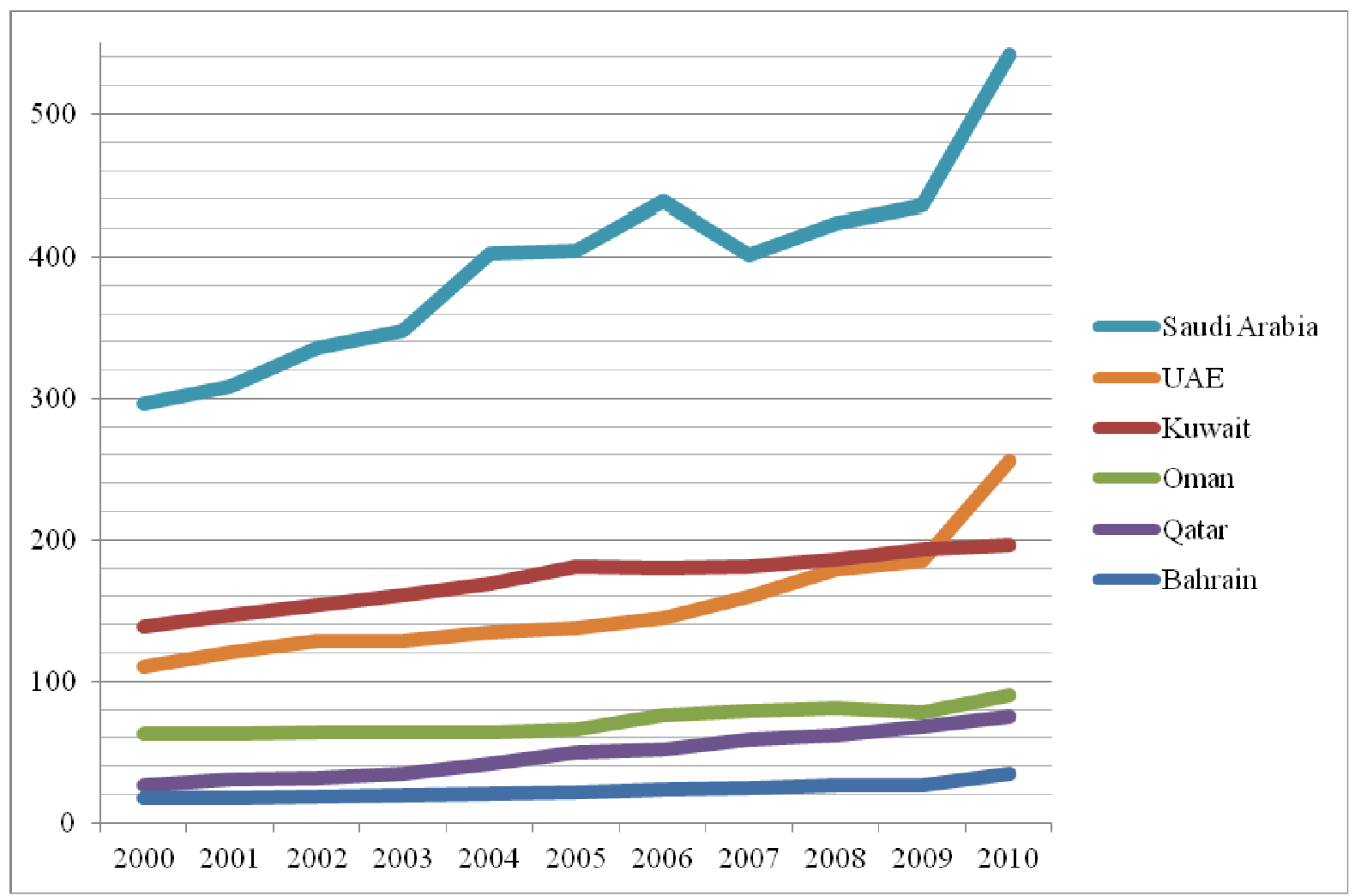

Greenhouse gas-wise carbon dioxide is the dominant source of greenhouse gas emissions globally: in 2010, according to data from the WRI, 70.3 percent of global emissions (including LUCF) came from $\mathrm{CO}_{2}$ (excluding LUCF). In the case of the GCC states, there is great variation, with $\mathrm{CO}_{2}$ accounting for 87-94 percent in the UAE, Bahrain, Saudi Arabia and Qatar, but only 45-58 percent of total emissions in Kuwait and Oman. ${ }^{150}$ Whilst it should be noted that high uncertainties are associated with data on non- $\mathrm{CO}_{2}$ gases, ${ }^{151}$ there are important patterns to observe, in the case of methane $\left(\mathrm{CH}_{4}\right)$. Methane emissions in the GCC originate primarily from the energy sector. ${ }^{152}$ In Kuwait, methane $\left(\mathrm{CH}_{4}\right)$ emissions in 2010 were estimated to account for 54.4 percent $\left(107.0 \mathrm{MtCO}_{2} \mathrm{e}\right)$ of all emissions, and in Oman, 40.5 percent (36.6 $\left.\mathrm{MtCO}_{2} \mathrm{e}\right)$. Volume-wise, Saudi Arabia's and the UAE's estimated $\mathrm{CH}_{4}$ emissions (32.8 and $26.2 \mathrm{MtCO}_{2} \mathrm{e}$, respectively) were also large. Methane emissions saw diverging trajectories in the three states over the 2000s, as follows: in Kuwait, the UAE

\footnotetext{
149 Ibid

150 Ibid. Bahrain: 87.9\%; Kuwait: 44.5\%; Oman: 58.3\%; Qatar: 93.9\%; Saudi Arabia: 90.7\%; UAE: 86.6\%.

${ }^{151}$ WRI, CAIT 2.0: Country Greenhouse Gas Sources \& Methods (WRI, 2013), 10.

152 Based on 2010 data from: IEA, CO $C_{2}$ Emissions from Fuel Combustion, 2013 edition (Paris: OECD/IEA, 2013), III.50.
} 
and Saudi Arabia, $\mathrm{CH}_{4}$ emissions grew by 24, 23 and 19 percent, respectively, whilst in Oman they decreased by 9 percent over this period.

The energy sector is the major contributor of GHG emissions, both globally (69 percent in 2009) and in the GCC (over 95 percent, on average, in 2009), as shown in Table 2, with minor contributions (approximately 1-4 $\mathrm{MtCO}_{2} \mathrm{e}$ ) coming from industrial processes, waste and bunker fuels. In addition, given the larger size of the country, more important absolute contributions (13.1-23.9 $\mathrm{MtCO}_{2} \mathrm{e}$ ) came from these sectors, as well as agriculture, in Saudi Arabia. In the UAE, industrial processes and bunker fuels ( 9.3 and $50.4 \mathrm{MtCO}_{2} \mathrm{e}$, respectively) were large in absolute terms but small compared to energy. ${ }^{154}$

Table 2: Energy sector greenhouse gas emissions in the GCC states, 2009. ${ }^{155}$

\begin{tabular}{|c|c|c|c|c|c|}
\hline $\begin{array}{c}\text { Share of } \\
\text { energy of total } \\
\text { emissions }\end{array}$ & $\begin{array}{c}\text { Share of } \\
\text { electricity and } \\
\text { heat of energy } \\
\text { emissions }\end{array}$ & $\begin{array}{c}\text { Share of } \\
\text { manufacturing } \\
\text { \& construction } \\
\text { of energy } \\
\text { emissions }\end{array}$ & $\begin{array}{l}\text { Share of } \\
\text { transport of } \\
\text { energy } \\
\text { emissions }\end{array}$ & $\begin{array}{c}\text { Share of other } \\
\text { fuel } \\
\text { combustion of } \\
\text { energy } \\
\text { emissions }\end{array}$ & $\begin{array}{c}\text { Share of } \\
\text { fugitive } \\
\text { emissions of } \\
\text { energy } \\
\text { emissions }\end{array}$ \\
\hline \multicolumn{6}{|l|}{ Bahrain } \\
\hline $87.8 \%$ & $52.1 \%$ & $29.0 \%$ & $14.0 \%$ & $1.2 \%$ & $3.7 \%$ \\
\hline \multicolumn{6}{|l|}{ Kuwait } \\
\hline $96.4 \%$ & $30.4 \%$ & $6.4 \%$ & $6.2 \%$ & $0.3 \%$ & $56.8 \%$ \\
\hline \multicolumn{6}{|l|}{ Oman } \\
\hline $98.9 \%$ & $30.1 \%$ & $10.4 \%$ & $7.3 \%$ & $3.7 \%$ & $48.5 \%$ \\
\hline \multicolumn{6}{|l|}{ Qatar } \\
\hline $99.2 \%$ & $46.2 \%$ & $24.4 \%$ & $12.6 \%$ & $3.1 \%$ & $13.6 \%$ \\
\hline \multicolumn{6}{|l|}{ Saudi Arabia } \\
\hline $96.3 \%$ & $54.4 \%$ & $18.6 \%$ & $23.9 \%$ & $1.2 \%$ & $1.8 \%$ \\
\hline \multicolumn{6}{|l|}{ UAE } \\
\hline $95.8 \%$ & $33.3 \%$ & $36.3 \%$ & $14.3 \%$ & $3.7 \%$ & $12.4 \%$ \\
\hline \multicolumn{6}{|l|}{ World } \\
\hline $68.9 \%$ & $42.8 \%$ & $18.6 \%$ & $17.8 \%$ & $12.9 \%$ & $7.9 \%$ \\
\hline
\end{tabular}

i) Including land use and forestry. // Nb. Two major sources of emissions are marked in bold.

Within the energy sector, electricity and heat are the major source of emissions (30-54 percent in 2009) in four of the GCC states, at least partly attributable to an electricity mix dominated by natural gas and oil (see Table 2 and Figure 3). In 2009, manufacturing and construction accounted for 24-36 percent of emissions in Qatar, Bahrain and the UAE, and 6-19 percent in the other three. In Saudi Arabia, transport was the second largest contributor to energy emissions (24 percent). In the other states, transport produced 6-14 percent of the sector's emissions. Importantly, the internationally standards for reporting sectoral emissions do not always give a nuanced enough picture of individual states: the large share of the export sector of the GCC states' economies, for example, is not visible. Domestic data from Qatar, for example, found that, in 2007, industries

\footnotetext{
${ }^{153}$ WRI, 'CAIT 2.0', accessed in October 2013. Notably, owing to different methodologies, data from WRI and IEA present inconsistencies. Given the accessibility of WRI data and the broad range of sources it uses, the author chose to use it wherever possible, for consistency. According to the WRI, the use of a consistent methodology across all countries can lead to situations in which the estimates differ from e.g. country-reported calculations, even significantly in some sectors. For methane, WRI uses data from U.S. EIA. Source: Personal correspondence with WRI online data and communications department, November 2013.

154 Ibid. International bunker fuels are not included countries' total emissions.

$155 \mathrm{lbid}$. Data for sectors and subsectors was only available until 2009.
} 

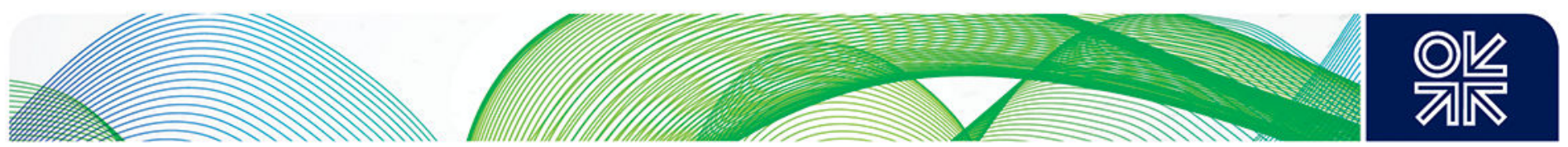

accounted for 67 percent of the country's total $\mathrm{CO}_{2}$ emissions, of which 12 percent were from flaring. ${ }^{156}$

Data on fugitive emissions is a complicated category, given the uncertainties associated to data (see also footnote 153). According to WRI data, in Kuwait and Oman, fugitive emissions constituted 57 percent and 49 percent of energy sector emissions, respectively. However, data from other sources is somewhat contrasting: according to Kuwait Oil Company, it has cut flaring from 17.2 percent in 2007 to 1.1 percent as a share of gas produced (or 96 percent compared to 2005 levels). ${ }^{157}$ In terms of volumes of gas flared, according to the World Bank's gas flaring reduction partnership GGFR, Saudi Arabia has the highest volumes $(3.7 \mathrm{bcm}$ in 2011$)$ of all GCC states and ranks as the $9^{\text {th }}$ major source of flaring in the world and $3^{\text {rd }}$ in the Middle East. Qatar and Oman are also global top-20 'flarers', with 1.7 and $1.6 \mathrm{bcm}$ of gas flared in 2011 , respectively. ${ }^{158}$ (Kuwait does not appear on the World Bank's top 20 list.)

Figures 2 and 3 provide a graphical illustration of the shares of natural gas and oil in electricity generation and the total primary supply of energy in the six states. In Kuwait and Saudi Arabia, oil plays a major role in electricity generation: 75 and 54 percent, respectively, in 2010 . Oil also accounts for a major share of the TPES in the two countries: 64 and 61 percent, respectively, with a slight proportional increase in Kuwait and a decrease in Saudi Arabia, over the 2000s. In the other four states, natural gas dominates in the electricity sector as well as in the primary energy supply. Qatar is the least dependent on oil, with its electricity sector functioning fully with natural gas and oil representing 11 percent of its primary supply in 2010.

Figure 2: Shares of energy sources in electricity generation in the GCC states, $2000 \& 2010 .^{159}$

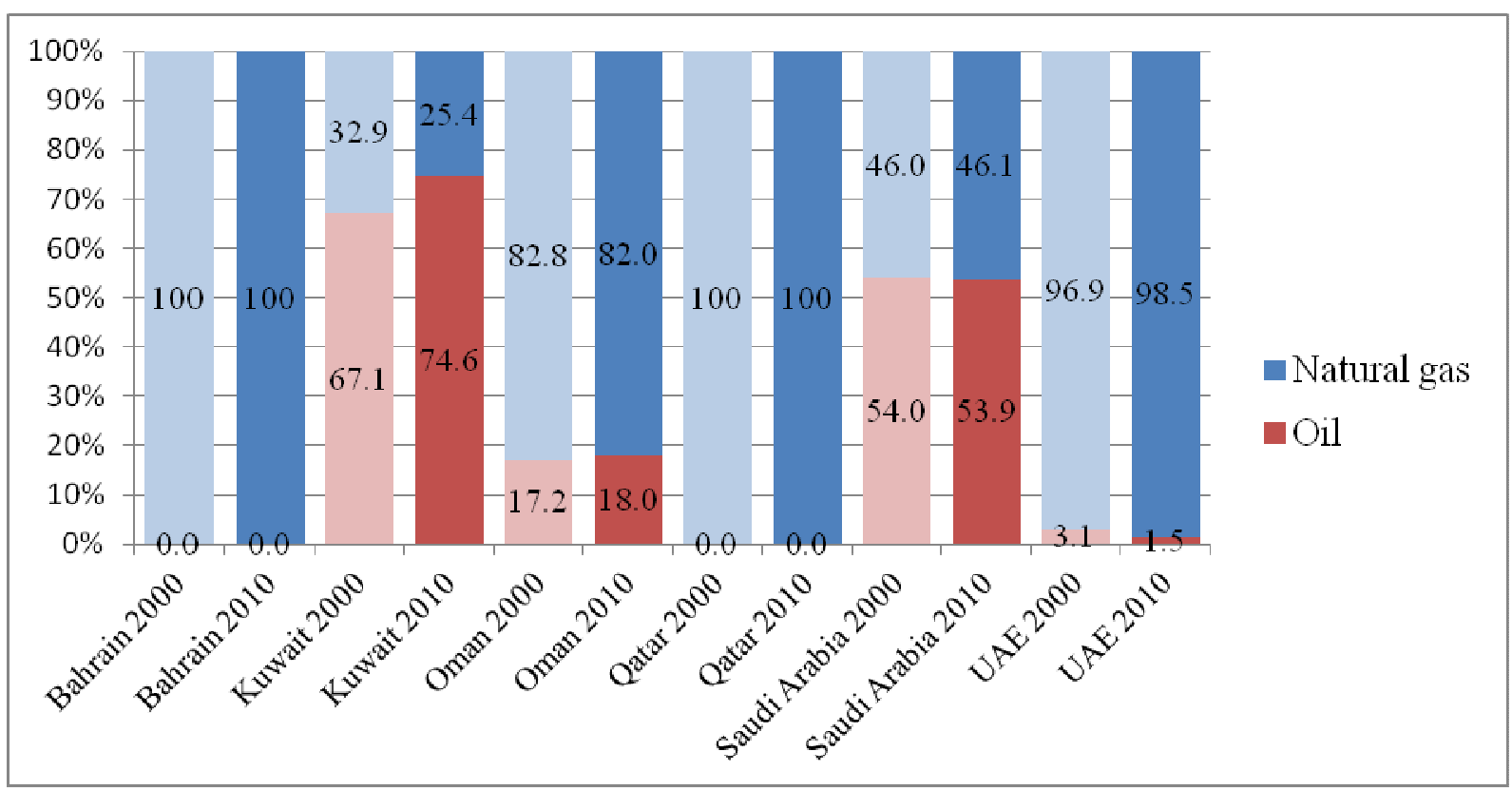

\footnotetext{
${ }^{156}$ General Secretariat for Development Planning (Qatar), Qatar National Development Strategy 2011-2016 (Doha: GSDP, 2011), 223.

${ }^{57}$ Kuwait Oil Company, 'Gas Flaring Reduction at Kuwait Oil Company', presentation, 13 February 2012.

${ }^{158}$ Global Gas Flaring Reduction Partnership, 'Estimated Flared Volumes from Satellite Data, 2007-2011' [http://go.worldbank.org/G2OAW2DKZ0], accessed in November 2013.

IEA, Energy Balances of Non-OECD, II, 357-9.
} 
Figure 3: Shares of energy sources in primary energy supply in the GCC states, 2000 \& 2010. ${ }^{160}$

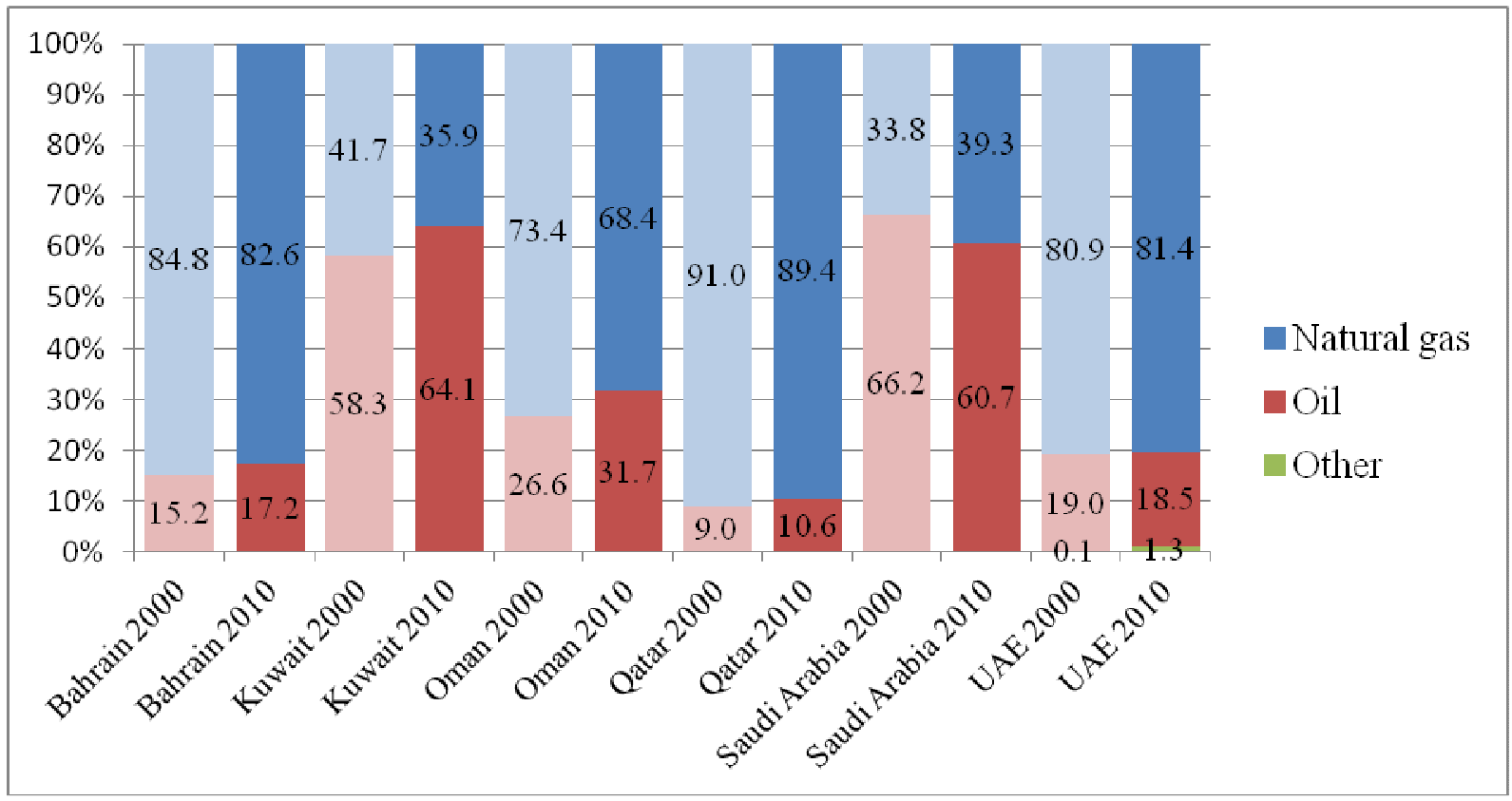

Given that energy is the major source of emissions globally, as well as in the GCC, a closer look at energy-related statistics is merited. Two indicators often used for trajectories and target-setting in climate policy are energy intensity and carbon intensity. The former measures the efficiency of energy use in the economy (TPES/GDP) and the latter $\mathrm{CO}_{2}$ emissions produced per currency unit of GDP. ${ }^{16}$ Whilst $\mathrm{CO}_{2}$ /energy serves to measure the carbon intensity of the energy supply, carbon intensity of the economy $\left(=(\mathrm{TPES} / \mathrm{GDP}) \times\left(\mathrm{CO}_{2} / \mathrm{TPES}\right)\right)$ can be used as an indicator of levels and trends in decarbonisation in the economy.

In the Middle East region, as the IEA notes, energy efficiency still remains a central challenge: energy supply growth since the 1980s been faster than economic output, leading to growing energy intensity, which in 2010 was nearly twice the global average. ${ }^{162}$ In the GCC, there is more variation, despite the large role of oil and natural gas production: in 2010, energy intensity in Qatar had dropped to 0.24 , from 0.36 in 2000, which was below the global average $(0.25) .{ }^{163}$ Other GCC states fared worse than this, with Bahrain (0.55) at the other extreme, above the Middle East (0.51) and non-OECD averages (0.52) (see Table 3). Moreover, compared to 2000 levels, with the exception of Qatar, a negative trend prevailed, as growth in energy use in Kuwait, Oman, Saudi Arabia and the UAE over the 2000s was faster than GDP growth, which led to an increase in energy intensity in these economies. ${ }^{164}$

Another indicator of low-emission transitions is the carbon intensity of the energy supply. In 2010, Qatar's and Saudi Arabia's energy use was less carbon intensive than that of the world (0.57), nonOECD (0.57) and OECD averages (0.55). However, 2011 saw an important reversal of this positive

\footnotetext{
160 Ibid., II, 333-49.

${ }^{161}$ E.g. IEA uses the former and the US EIA, WWF and the Chinese government (for its 2020 emissions target) the latter.

162 IEA, Energy Balances of Non-OECD, xix.

163 Ibid., Il.434. toe/thousand 2005 US\$. Nb.

164 Ibid., II.434. Given the different data used in calculations there are diverging results regarding energy intensity performance if compared with Table 1. (IEA uses 2005 US\$ and the author has used constant local currencies in Table 1.)
} 
trend in the case of Saudi Arabia, where it reached 0.58. In 2010, Kuwait, the UAE, Oman and Bahrain remained above even the Middle East average (0.58) on this indicator. ${ }^{165}$

By combining these two measures, an indicator of the economy's carbon intensity can be drawn. As shown in Table 3, Qatar and the UAE are closest to the global average and furthest of the six states on the road to low-emission economy. In 2010, Kuwait, Saudi Arabia and Oman were middle performers and Bahrain fared the worst. An examination of intensity trends from 2000 to 2010 reveals divergence: intensity decreased significantly in Qatar (-3.7\%) and somewhat in Bahrain and Kuwait, but increased in Saudi Arabia, the UAE and Oman, in the last one a significant 4.5 percent.

Table 3: Carbon intensity of GCC economies, 2000-2010. ${ }^{166}$

\begin{tabular}{|c|c|c|c|}
\hline $\begin{array}{l}\text { Energy intensity of the } \\
\text { economy } \\
(\mathbf{2 0 1 0 )} \\
\text { toe/ US } \$ 1,000^{i}\end{array}$ & $\begin{array}{c}\text { Carbon intensity of } \\
\text { energy supply } \\
(2010) \\
\mathrm{tCO}_{2} / \mathrm{TJ} / 1,000^{\mathrm{ii}}\end{array}$ & $\begin{array}{l}\text { Carbon intensity of the } \\
\text { economy } \\
(\mathbf{2 0 1 0}) \\
(\text { emission intensity }) \times \\
\left(\mathrm{CO}_{2} \text { intensity of energy }\right)\end{array}$ & $\begin{array}{c}\text { Change in carbon } \\
\text { intensity of the } \\
\text { economy } \\
(2000-2010) \\
\text { CAGR }\end{array}$ \\
\hline \multicolumn{4}{|l|}{ Bahrain } \\
\hline 0.55 & 0.58 & 0.32 & $-0.60 \%$ \\
\hline \multicolumn{4}{|l|}{ Kuwait } \\
\hline 0.36 & 0.60 & 0.21 & $-0.46 \%$ \\
\hline \multicolumn{4}{|l|}{ Oman } \\
\hline 0.47 & 0.59 & 0.28 & $4.52 \%$ \\
\hline \multicolumn{4}{|l|}{ Qatar } \\
\hline 0.24 & 0.52 & 0.13 & $-3.72 \%$ \\
\hline \multicolumn{4}{|l|}{ Saudi Arabia } \\
\hline 0.47 & 0.55 & 0.26 & $1.23 \%$ \\
\hline \multicolumn{4}{|l|}{ UAE } \\
\hline 0.29 & 0.60 & 0.17 & $1.96 \%$ \\
\hline \multicolumn{4}{|l|}{ World } \\
\hline 0.25 & 0.57 & 0.14 & $0.00 \%$ \\
\hline
\end{tabular}

i) 2005 US\$.

ii) The indicator has been divided by 100 for better comparability.

\subsubsection{GHG Emission Scenarios}

Given the fast growth trends in the GCC, future emission projections can provide, at best, general ideas of expected emission trends in the region. Scenarios examined were the US EIA's International Energy Outlook 2013 and the IEA's World Energy Outlook 2012, both of which measure energyrelated $\mathrm{CO}_{2}$ emissions and were only available for the entire Middle East region. (In 2010, the GCC states accounted for 52.5 percent of the region's emissions. ${ }^{167}$ ) In the US EIA's reference scenario, global emissions increase by an average rate of 1.3 percent per year between 2010 and 2040 (compared to 1.9 percent in 1990-2010). ${ }^{168}$ Emission growth in the Middle East is higher but slows down considerably: from 4.6 percent per year $(1990-2010)$ to 1.7 percent (2010-2040). The IEA's Current Policies Scenario (a continuation of policies and measures in place by mid-2012) projects global emissions to grow by 1.5 percent per year between 2010 and 2035, which is consistent with a global warming of $5.3^{\circ} \mathrm{C}$ by the end of the century. In this scenario, Middle East $\mathrm{CO}_{2}$ emissions from energy increase by 2.1 percent per year. In the 450 Scenario (derived from the corresponding level of

\footnotetext{
165 IEA, $\mathrm{CO}_{2}$ Emissions from Fuel Combustion, II.46-8. The indicator has been divided by 100 for better comparability.

${ }^{166}$ IEA, Energy Balances of Non-OECD, II, 434; $\mathrm{CO}_{2}$ Emissions from Fuel Combustion, II.48.

${ }^{167} \mathrm{CO}_{2}$ emissions from energy. IEA, $\mathrm{CO}_{2}$ Emissions from Fuel Combustion, III.50.

168 US EIA, 'International Energy Outlook 2013, Table 21.' [http://www.eia.gov/forecasts/ieo/table21.cfm], accessed in October 2013.
} 

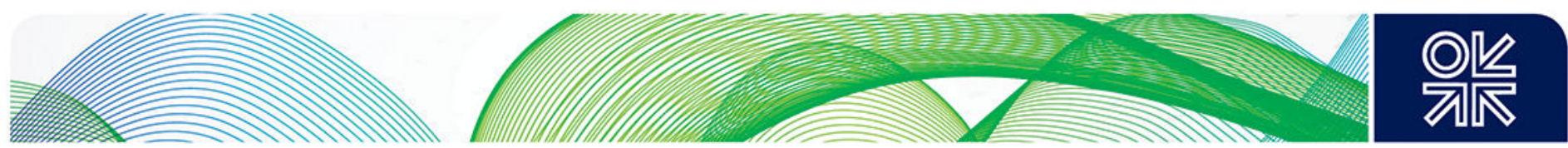

concentration of $\mathrm{CO}_{2}$ in the atmosphere), global emissions decrease by 1.2 percent per year, by 2035, with a 50 percent chance of preventing a dangerous global warming. In this scenario, Middle East emissions grow by 0.3 percent per year. ${ }^{169}$ It is evident from these scenarios that, on the one hand, emission growth in the Middle East is expected to slow down considerably and, on the other, if climate change is seen as a policy priority, policies should focus on achieving emission reductions, for example in relation to baseline scenarios.

Up to the time of writing no GCC government had published economy-wide emission projections, which can be seen to result from a mix of lacking capacity and political interest, but also the political sensitivities associated in many GCC states with producing data to support (external calls for) emission abatement policies. ${ }^{170}$ The UAE's Ministry of Environment and Water, however, has supported an ecological footprint data project that included carbon emission calculations for the emirate of Abu Dhabi. In addition, at least three independent studies have modelled emission trajectories and related mitigation potential in the emirate of Abu Dhabi, possibly reflecting the general predisposition of the government to tackle emissions.

In a government-supported modelling study from 2010, the Masdar Institute and Emirates Wildlife Society-WWF examined the impact of different policy choices for the electricity and water sector (planned at the time) for Abu Dhabi's $\mathrm{CO}_{2}$ emissions by 2030. The examined reduction range in three scenarios was 11.6-38.4 percent compared to a 2030 baseline of approximately $180 \mathrm{MtCO}_{2}$ in 2030. ${ }^{171}$ In the most ambitious scenario, measures in the building and transports sectors, decarbonisation of the energy mix (by alternative energies, renewable and CCS), efficient appliance standards, and new desalination and wastewater recycling infrastructure resulted in a reduction of approximately $70 \mathrm{MtCO}_{2}$ compared to the 2030 baseline - equivalent to over a quarter of the UAE's total annual GHG emissions in 2010.

In 2010, Chinery produced a model for projecting emissions in Abu Dhabi's transport sector from 2005 until 2030. Focusing on the emirate's passenger fleet, the model examined the impact of fuel economy and compressed natural gas (CNG) vehicles (10 percent of the total fleet) on sectoral GHG emissions. The author found that the examined measures would result in a 10 and 5 percent reduction from the baseline, respectively, and that fuel efficiency was a significantly cheaper option. ${ }^{172}$

In a study from 2011, Smeets and Bayar examined Abu Dhabi's total $\mathrm{CO}_{2}$ emissions under several growth and emission abatement policy scenarios up to 2020. In the central baseline scenario, predicting the emirate's total emissions at $151.5 \mathrm{MtCO}_{2}$ in 2020 (with an annual average growth of 5.7 percent from $81.8 \mathrm{MtCO} 2$ in 2009), the authors found that utility price liberalisation in the industry sector would lead to an emission reduction of 16 percent from the corresponding baseline (105.3 $\mathrm{MtCO}_{2}$ in 2020). In the household sector, price liberalisation and 20 percent energy efficiency gains (achieved through education, and/or reward systems) would reduce emissions by 21 percent from the corresponding baseline $\left(46.2 \mathrm{MtCO}_{2}\right)$. Energy efficiency measures in the desalination and electricity alone would result in up to a 12 percent drop from the total baseline emissions by 2020 . If efficiency measures were extended into the entire industry sector (through efficiency standards and/or investments in new, clean technologies), a deviation of up to 22 percent from the emission baseline in 2020 could be achieved. ${ }^{173}$

Finally, a study on the utilities sector in Abu Dhabi, from 2013, examined the impact of decreasing leakage in the water distribution system and decreasing residential water use (pricing and demand household management programmes) on GHG emissions from water desalination plants. The authors

\footnotetext{
169 IEA, World Energy Outlook 2012 (Paris: OECD/IEA, 2012), 34-5, 52, 555, 622.

${ }_{171}^{170}$ Personal communications in Doha, Abu Dhabi and Bonn, 2012-2013.

${ }^{171}$ Emirates Wildlife Society-WWF, UAE Ministry of Environment and Water, Environment Agency - Abu Dhabi and Global Footprint Network, UAE Ecological Footprint Initiative, supplement for the Living Planet Report 2010 (UAE, 2010), 7. Exact data for emissions not presented.

Leslie E. Chinery, Modeling Trasportation in Abu Dhabi: A 25-Year Projection of Emissions under Alternative Scenarios of the Passenger Fleet, Master's thesis (Chapel Hill: University of North Carolina, 2010), 42.

Bram Smeets and Ali Bayar, 'Sustainability of Economic Growth in Abu Dhabi - A Dynamic CGE Approach',

Topics in Middle Eastern and African Economies, Vol. 41, September 2012, 41-8, passim.
} 
concluded that demand side management was the most efficient measure (with a 10-11 percent reduction in emissions from the baseline when per capita reaches similar levels to those in Singapore or the UK), followed by full pricing (1-5 percent reduction) and reducing distribution losses to 15 percent (a 3 percent reduction). ${ }^{174}$ These four models are summarised below, in Table $4 .{ }^{175}$

Abu Dhabi's Future Energy Company Masdar has also produced (but not published) a carbon emissions abatement cost curve, based on a model by McKinsey, which found large saving potential in the electricity and water supply sector, and consequently recommended demand side management to the government. ${ }^{176}$

Table 4: Selected mitigation scenarios for Abu Dhabi.

\begin{tabular}{|c|c|c|}
\hline $\begin{array}{l}\text { Time } \\
\text { Authors }\end{array}$ & Reduction potential examined & Policies/measures \\
\hline \multicolumn{3}{|l|}{$2005-2030$} \\
\hline $\begin{array}{l}\text { Al-Basma Al-Beeiyah } \\
\text { Initiative }\end{array}$ & $\begin{array}{l}11.6-38.4 \% \text { of } \mathrm{CO}_{2} \text { emissions } \\
\text { baseline in } 2030 \\
\left(\max .70 \mathrm{MtCO}_{2}\right)\end{array}$ & $\begin{array}{l}\text { Efficiency and decarbonisation measures in } \\
\text { the electricity and water sector. }\end{array}$ \\
\hline \multicolumn{3}{|l|}{ 2005-2030 } \\
\hline Chinery & $\begin{array}{l}5-10 \% \text { of transport sector } \\
\text { emissions by } 2030\end{array}$ & $\begin{array}{l}\text { Fuel efficiency and compressed natural gas } \\
\text { vehicles in the transport sector. }\end{array}$ \\
\hline \multicolumn{3}{|l|}{ 2009-2020 } \\
\hline Smeets and Bayat & $\begin{array}{l}12-22 \% \text { of } \mathrm{CO}_{2} \text { emissions } \\
\text { baseline in } 2020 \\
\left(\max .33 \mathrm{MtCO}_{2}\right)\end{array}$ & $\begin{array}{l}\text { Price liberalisation and energy efficiency } \\
\text { measures in the industry and household } \\
\text { sectors. }\end{array}$ \\
\hline \multicolumn{3}{|r|}{ 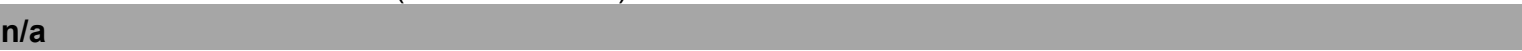 } \\
\hline DeFelice and MacDonald & $\begin{array}{l}1-11 \% \text { of water desalination- } \\
\text { related emissions in the } \\
\text { residential sector }\end{array}$ & $\begin{array}{l}\text { Demand management programmes and price } \\
\text { reform for residential sector and efficiency in } \\
\text { the utilities sector. }\end{array}$ \\
\hline
\end{tabular}

At least two kinds of conclusion can be drawn from the modelling studies examined: firstly, there is significant potential for emission reductions compared to baseline projections, both economy-wide and sector-specific. Most interestingly perhaps, as the government-supported scenario showed, significant reductions are already planned through regulation, fuel switching, deployment of clean technologies, and investments in infrastructure. In order to achieve the desired reductions, these obviously will need to be fully implemented, which calls for determined attention and action from the government. Secondly, as shown by the other studies, differences exist among the efficacy of measures: efficiency and demand side measures can play a major role in reducing emissions, and they are economically attractive options. Implementing new technologies is also important but technological solutions are not always the most cost-efficient option, as shown by the study on passenger vehicles. Utility pricing reforms can achieve important reductions, but must go hand in hand with awareness-raising to ensure sustained results in the household sector, as found by the economy-wide modelling study - and possibly to avoid a social backlash. Finally, despite the differences between sectoral distributions, the importance of the energy supply, industry and transport sectors for energy-related GHG emissions in all GCC states, the carbon intensity of GCC economies

\footnotetext{
${ }^{174}$ Nicholas B. DeFelice and Jacqueline MacDonald Gibson, 'Effect of Domestic Water Use on Air Pollutant Emissions in Abu Dhabi, United Arab Emirates', International Journal of Energy and Environmental Engineering, Vol. 4, 33 (2013), 1-10.

${ }^{175}$ In a further study, Radhi and Sharples examined the impact of climate change on $\mathrm{CO}_{2}$ emissions in the housing sector in the emirate of Abu Dhabi. Hassan Radhi and Steve Sharples, 'Forecasting Carbon Emissions of the UAE Residential Sector-A Case Study of Abu Dhabi', in Magali Bodart and Arnaud Evrard (eds), $27^{\text {th }}$ Conference on Passive and Low Energy Architecture, Belgium, July 2011, Proceedings, Vol. 1., 251-6.

${ }^{176}$ Personal interview, Abu Dhabi, October 2010.
} 

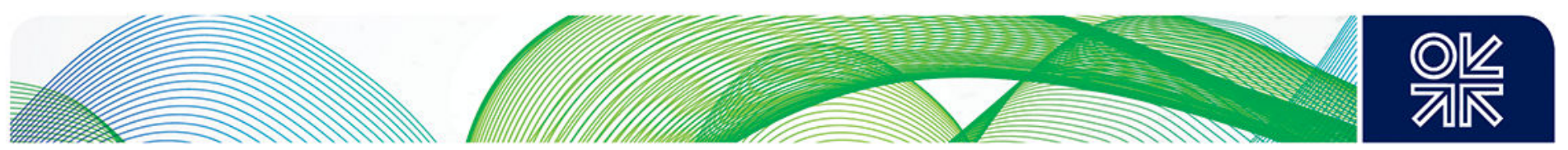

(see Tables 2-3), and the similarity of their national circumstances, makes these findings relevant for all six states.

\subsubsection{Capabilities and Vulnerabilities}

The concept of respective capabilities is a core principle of the UNFCCC. It relates to the role and division of labour of countries in preventing dangerous climate change, which they have agreed to conduct 'in accordance with their common but differentiated responsibilities and respective capabilities', with the developed countries taking the lead. ${ }^{177}$ Purely in present-time economic terms, the GCC states, although to a varying degree, are very well-placed to combat climate change and its adverse effects as well as those caused by a global shift to low-carbon. However, as noted above, the GCC states' historical responsibility in terms of global emissions (emitted domestically) is low and, as pointed out by some GCC governments, using GDP per capita or per capita emissions as measures of capability can be unfair, as other factors, beyond economic, affect the states' ability to act, including levels of social and human development and diversification and resilience of the economy. ${ }^{178}$ In any case, predetermining what the 'fair share' of the GCC states of the global mitigation burden is not the task of this study, but focus should rather be on what drives, or could drive, action, both in terms of expected vulnerabilities to climate change and global climate measures (as discussed below) and in terms of broader economic and social drivers that support a transition to low-emission economies (discussed in the next section).

In their national communications from 2011-2013, the GCC states (excluding Oman) describe their vulnerability to climate change as relating to variations in temperature, precipitation and sea level rise (SLR). ${ }^{179}$ Priority areas of expected impacts, where GCC states have also conducted the most assessments, are: coastal zones (inundation), water resources (seawater intrusion and increasing demand for desalinated water), public health (heat and air pollution-related illnesses), and biodiversity. ${ }^{180}$ The UAE also considers of critical importance understanding the impacts and interactions with climate change of water desalination and food security.

According to climate models cited in the Kuwaiti and Qatari communications, average annual temperatures in the Arabian Peninsula are expected to rise by $1-2^{\circ} \mathrm{C}$ by $2030-2050$, while rainfall is expected to decrease, with a possibility of increased dust storms. As a result, as Qatar's communication notes, there will be 'further desertification of the desert' and water and air-conditioning demand will increase leading, in turn, to higher levels of desalination, waste heat and GHG emissions. A scenario study in Bahrain found that a SLR of 0.3-1 metres would inundate 11-27 percent of the country's land surface, including 17-63 percent of industrial areas. For Qatar, economic impacts of 15 metre SLR have been estimated at 2-10 percent of the GDP.

In addition, a number of other studies on regional impacts and vulnerability have been published. For example, a recent climate model study led by the UK-based Hadley Centre projected average temperature increases of up to $4^{\circ} \mathrm{C}$ in Saudi Arabia by 2100 . Precipitation patterns are expected to mainly decrease (up to 20 percent). ${ }^{181}$ The study also projected crop yield losses (resulting from a combination of climate change and high demand for groundwater), increasing food insecurity, and low

\footnotetext{
177 UNFCCC, UNFCCC, art 3. See also Section 2.1.1.

178 See e.g. UNFCCC, document FCCC/AWGLCA/2009/MISC.1/Add.1, 16-7. Qatar has also pointed out elsewhere that its LNG industry in fact contributes to important emission reductions in the importer countries. While per capita emissions in Qatar have risen, as a result, the net global benefit from (an assumed) fuel switching is positive. UNFCCC, document FCCC/SBSTA/2002/MISC.3, 29. However, the polluter pays principle, another key principle of the UNFCCC, attributes the costs of pollution abatement to the party responsible for the pollution, in this case emissions produced on Qatar's territory.

Kingdom of Bahrain Public Commission for the Protection of Marine Resources, Environment and Wildlife, $2^{\text {nd }}$ NC; State of Kuwait Environment Public Authority, $1^{\text {st }} \mathrm{NC}$; State of Qatar Ministry of Environment, $1^{\text {st }} \mathrm{NC}$; Kingdom of Saudi Arabia, $2^{\text {nd }} \mathrm{NC}$; UAE Ministry of Energy, $3^{\text {rd }} \mathrm{NC}$.

180 lbid.

${ }^{181}$ Temperature: IPCC 4AR A1B scenario. Precipitation: Up to $20 \%$ increases, however, are projected in the south-eastern part of the country. Met Office/Hadley Centre, Climate: Observations, Projections and Impacts: Saudi Arabia (Exeter: Met Office, 2011), 1.
} 

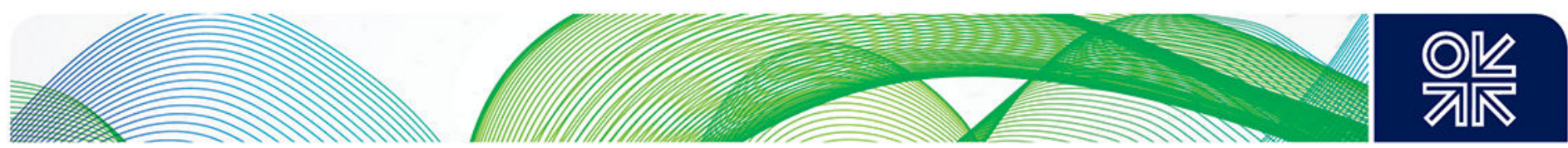

SLR impacts by large, but increased likelihood of vulnerability of large shares of coastal populations to extreme weather events like storms. ${ }^{182}$ In 2009, the Environment Agency - Abu Dhabi (EAD) published a set of studies on climate vulnerability and impacts focusing on coastal zones in the UAE and water resources and dryland ecosystems in Abu Dhabi. In SLR scenarios of 1-9 metres (the high end representing a scenario of accelerated ice cap melting), 334-1,672 $\mathrm{km}^{2}$ of Abu Dhabi's and 14$221 \mathrm{~km}^{2}$ of Dubai's total land area would be inundated (an area equivalent to up to 265,000 football fields in total), with major impacts in coastal areas and built up land in Dubai, in particular. ${ }^{183}$ The studies also found that the impact of climate change on water use would be marginal ( $<5$ percent) compared to population growth and high per capita demand. ${ }^{184}$

Capacity and data gaps, however, still exist: Qatar, a smaller state, has called for (more) lowresolution, regional climate models for supporting the development of reliable climate and sea level change scenarios and, consequently, accurate vulnerability studies. The EAD studies, too, called for more detailed data to support adaptation policy-making and better understanding of extreme weather events. $^{185}$

GCC states, in particular Saudi Arabia, Kuwait and Qatar, often describe themselves as doubly vulnerable to climate change, given their high dependence on fossil fuel revenues for economic (and social) stability and sustainability, and limited options for economic diversification. ${ }^{186}$ In the scope of the UNFCCC, including in their national communications, the GCC have described in great length their vulnerabilities in relation to climate change impacts and climate change mitigation response measures. Saudi Arabia's national communication from 2011 argues that the impact of Annex I mitigation policies on oil-exporting countries' economies is undoubted and that the extent will depend on how vulnerable the economy is to negative oil demand and price shocks, which in turn relates to levels of dependence on oil revenue, demographic pressures (population growth and need to maintain living standards), and opportunities for diversification outside the oil sector. Saudi Arabia's communication also points out that Annex I countries' response measures not only impact the Saudi economy through mitigation actions (which lead to reduced demand and prices of hydrocarbons) but also through rising prices of imports of consumer and capital goods from Annex I countries (through restrictions on the use of 'hydrocarbon energy', which lead to increasing production costs). The latest Saudi communication also lists the response measures (in importing countries) that most affect its economy, namely: direct or indirect taxes on petroleum products; subsidies to alternative fuels; mandatory fuel switching or mixing in the transport sector; and trade measures targeting petroleum imports. ${ }^{18}$

A survey of existing literature by the author in 2011 revealed great variation between potential economic revenue loss scenarios for OPEC member states: some predicted major losses as a result of Annex I countries' implementation of their Kyoto Protocol first commitment period targets (20082012) - which obviously did not materialise; others predicted anything between losses of a third of export revenues, compared to baselines by 2050 , to increased revenues under a universal mitigation regime. A lot of politics is also involved: OPEC's own models predict losses, whilst those of the IEA have focused on the larger size of expected future revenues, in absolute terms, compared to past revenues. ${ }^{188}$ So far, no estimates on the economic implications of having to leave oil in the ground have been published.

\footnotetext{
182 Ibid., 2-3.

183 Environment Agency - Abu Dhabi (EAD), Climate Change Impacts, Vulnerability and Adaptation (Abu Dhabi: EAD, 2009), 49. Football field size used: $7140 \mathrm{~m}^{2}$.

184 Ibid., 118-9.

185 lbid., 57

${ }^{186}$ See e.g. State of Qatar Ministry of Environment, $1^{\text {st }}$ NC, 28; Kingdom of Saudi Arabia, $2^{\text {nd }}$ NC, 46.

${ }^{187}$ Kingdom of Saudi Arabia, $2^{\text {nd }}$ NC, 44, 48.

${ }^{188}$ Mari Luomi, Greening for Self-Conservation? Energy Security and Responses to Climate Change in the Small Gulf Monarchies, PhD thesis, (Durham: University of Durham, 2011), 87-90.
} 


\subsubsection{Institutional Arrangements}

The governance of climate change in the GCC can be, for analytical purposes, divided into international and domestic, with the former formulating the countries' UNFCCC policies and the latter working with climate change-related policies and measures domestically. In the GCC, the former structures, albeit narrow, are more developed, with clearly defined roles and activities.

Vis-à-vis the UNFCCC, states are represented through national focal points (NFP), which are most commonly located in environmental authorities, or ministries of foreign affairs. In Bahrain, Kuwait and Oman this contact point is located in the environmental authority; in Qatar it was moved temporarily, in 2012, from the Ministry of Environment into the Ministry of Foreign Affairs (for the duration of the COP 18/CMP 8 conference); the UAE has two contact points; and in Saudi Arabia, it is in the Ministry of Petroleum and Mineral Resources (see Table 5). For participation in the Clean Development Mechanism (CDM), countries must designate a national authority (DNA) that approves projects at the national level and facilitate participation in the mechanism. ${ }^{189}$ All GCC states have established DNAs, in most cases located in the same institutions as the NFPs. In addition, many GCC states have established interagency committees for preparing the national communications to the UNFCCC and for national policy coordination purposes, as shown in Table 5. For example, the UAE's National Climate Change Committee (NCCC), chaired by the UAE's Environment Minister, sets the strategic direction for national-level climate policy. ${ }^{190}$ In Qatar, too, the NCCC is given the task of establishing a comprehensive climate change programme, including mitigation policies. ${ }^{191}$

Table 5: Government entities responsible for climate change policy. ${ }^{192}$

\begin{tabular}{lll}
\hline $\begin{array}{l}\text { UNFCCC National Focal } \\
\text { Point(s) (NFP) }\end{array}$ & $\begin{array}{l}\text { CDM Designated National } \\
\text { Authority (DNA) }\end{array}$ & $\begin{array}{l}\text { National climate change committees } \\
\text { (National policy/UNFCCC reporting) }\end{array}$ \\
\hline $\begin{array}{l}\text { Bahrain } \\
\begin{array}{l}\text { Public Commission for the } \\
\text { Protection of Marine Resources, } \\
\text { Environment and Wildlife }\end{array}\end{array}$ & $\begin{array}{l}\text { Public Commission for the } \\
\text { Protection of Marine } \\
\text { Resources, Environment and } \\
\text { Wildlife }\end{array}$ & $\begin{array}{l}\text { National Climate Change Joint Committee } \\
\text { (policy); National Climate Change Steering } \\
\text { Committee (NCs) }\end{array}$ \\
$\begin{array}{l}\text { Kuwait } \\
\text { Environment Public Authority }\end{array}$ & Environment Public Authority & $\begin{array}{l}\text { Kuwait National Committee on Climate } \\
\text { Change }\end{array}$ \\
$\begin{array}{l}\text { Oman } \\
\text { Ministry of Environment and } \\
\text { Climate Affairs }\end{array}$ & $\begin{array}{l}\text { Ministry of Environment and } \\
\text { Qatar }\end{array}$ & nla \\
$\begin{array}{l}\text { Ministry of Foreign Affairs } \\
\text { (during COP 18); Ministry of }\end{array}$ & Ministry of Environment & National Climate Change Committee \\
Environment & & (chaired by the Ministry of Environment)
\end{tabular}

\section{Saudi Arabia}

Ministry of Petroleum and

Ministry of Petroleum and

$\mathrm{n} / \mathrm{a}$

Mineral Resources

Mineral Resources

\footnotetext{
${ }^{189}$ UNFCCC CDM, 'Governance’ [http://cdm.unfccc.int/EB/governance.html], accessed in October 2013.

190 UAE Ministry of Energy, $3^{\text {rd }}$ NC, 12.

191 State of Qatar Ministry of Environment, $1^{\text {st }}$ NC, 18.

192 UNFCCC, 'National Focal Points' [http://maindb.unfccc.int/public/nfp.pl]; 'Designated National Authorities' [http://cdm.unfccc.int/DNA/index.html]; CDM-DNA UAE, 'DNA UAE' [http://www.cdm-

uae.ae/portal/menu.authority.aspx]; OAPEC, 'Biography of H.E. Secretary General, OAPEC'

[http://www.oapecorg.org/sgecv.html], all accessed in October 2013; GCC NCs to the UNFCCC from 2011-2013.
} 

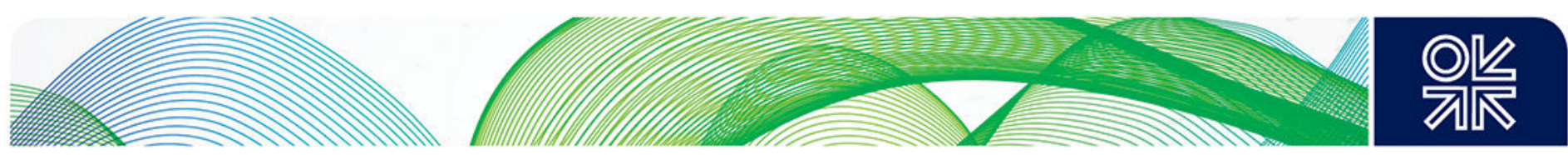

\section{UAE (federal)}

Ministry of Foreign Affairs;

Ministry of Environment and

Water
Environment Agency - Abu

Dhabi (host)
National Climate Change Committee

(policy, chaired by the Ministry of

Environment and Water); National

Communications Executive Committee

(chaired by the Ministry of Energy)

Of the six states, two have established dedicated institutions for climate policy: Oman's Ministry for Environmental and Climate Affairs was established in 2007 and the UAE's Directorate of Energy and Climate Change (DECC), under the Ministry of Foreign Affairs, in $2010{ }^{193}$ In Oman, the Ministry is the main institution responsible for climate change-related policies and regulation. The UAE's DECC is responsible for representing the federation in international negotiations, supporting a national climate change strategy, and liaising with the International Renewable Energy Agency (IRENA), headquartered in Abu Dhabi. The DECC also serves as the secretariat to the UAE's NCCC. (See Table 5.)

Multi-stakeholder participation that extends beyond the government is considered an important aspect of good governance. ${ }^{194}$ An interesting example is the Abu Dhabi Sustainability Group, a coordination mechanism for sustainability management, established in 2009 on the initiative of the Environment Agency - Abu Dhabi (EAD), which brings together members from the government, businesses and non-profit organisations. ${ }^{195}$ In Qatar, the short-lived Qatar Sustainability Network (QSN) was established as a non-governmental organisation for advancing 'the culture of research, science and sustainability' in the run-up to the 2012 UN Climate Change Conference in Doha, and had nearly 20 member organisations from the public, private and non-profit sectors. However, QSN ceased to exist shortly after, in $2013 .{ }^{196}$

In addition, there are a number of other government agencies, government-owned companies, and even some private and international companies and civil society organisations that have been active in climate mitigation-related activities in the GCC, including the CDM. Given the UAE's confederal system, and Abu Dhabi's autonomous local-level policymaking and leadership interest in sustainability, the emirate has been particularly active in this sense. In Abu Dhabi, these additional actors include: government-owned energy corporations Masdar (Abu Dhabi Future Energy Company, ADFEC), Abu Dhabi Water and Electricity Authority (ADWEA), Abu Dhabi National Oil Company (ADNOC), and Emirates Nuclear Energy Corporation (ENEC); the Urban Planning Council; and Emirates Wildlife Society-WWF, among others. In Qatar, Qatar Petroleum has a CDM Committee; Qatar Foundation institutions have been active in research and research and development in the areas of energy and environment; and the Qatar National Food Security Programme is working on clean energy-powered solar desalination and other measures for increasing domestic agricultural production sustainably and strengthening the climate resilience of the agricultural sector. In Saudi Arabia, in turn, additional climate action-relevant institutions include: King Abdullah City for Atomic and Renewable Energy (K.A.CARE), King Abdullah University of Science and Technology (KAUST), and the Saudi Energy Efficiency Center (SEEC), under King Abdul Aziz City for Science and Technology (KACST).

\footnotetext{
${ }^{193}$ Omanuna, 'Our Environment'

[http://www.oman.om/wps/portal/!ut/p/c4/04_SB8K8xLLM9MSSzPy8xBz9CP0os3hjA3cDA39LT18Tp0AXAyMvl2 TYEdjl4NgE 2CbEdFAJCSMWg!/?WCM PORTLET=PC 7 30G0009IMSB9102BG2LM6PHSO3000000_WC M̄\&CM_GLŌBAL_CONTEXT=/wps/wcm/connect/ar/site/home/environment/envior\#p2]; UAE Ministry of Foreign Affairs, 'Energy \& Climate Change' [http://www.mofa.gov.ae/mofa_english/portal/2666c727-3cea-44839791-56462f752166. aspx]; both accessed in October 13.

${ }^{194}$ In the context of LEDS, see e.g. Lütken et al., Low Carbon Development Strategies, 6-7.

195 Abu Dhabi Sustainability Group, 'About Us' [http://www.adsg.ae/about/Pages/AboutUsHome.aspx], accessed in October 2013.

${ }^{196}$ Qatar Sustainability Network, 'Members' [http://www.qsnetwork.org/], accessed in October 2013; personal correspondence.
} 


\subsection{Status of Mitigation Policy and Measures}

There is marked variation in the GCC states' activeness in climate action to date, if measured in terms of plans, initiatives and actions (in other words, material for analysis). This section examines emerging mitigation policy and actions the GCC states in general, but has a special focus on the three most active ones: the United Arab Emirates, Qatar and Saudi Arabia.

Despite the similarities shown by Section 3.1, there are some differences amongst the GCC states' national circumstances and emissions that should be kept in mind as these will influence each country's eventual policy choices. For the three states examined in more detail, these include the following ones: the UAE and Qatar are smaller than Saudi Arabia in terms of economy and population; the UAE is a confederation with a two-level decision-making system; Qatar is a major natural gas exporter and Saudi Arabia the key oil exporter; the UAE is the most economically diversified but Qatar's domestic energy security is boosted by availability of natural gas; Qatar and the UAE are further on the road to low-emission economies than Saudi Arabia; and whilst Saudi Arabia's total GHG emissions are relatively large compared to the two others, the UAE and Qatar have some of the world's highest ecological footprints, of which the former is acutely aware. Owing to differences in economic wealth and political systems and environments, there is also some variability in terms of the economic capabilities and political autonomy of governments to take action. The three states examined in the following sections are either wealthy in terms of GDP/capita and their governments act autonomously in decision-making (UAE and Qatar), or their overall economic size, and consequently larger total hydrocarbon revenues, give them a bigger impetus and broader scope for action (Saudi Arabia). Further differences emerge when the three other GCC states are examined. However, despite the differences, important similarities among all GCC states' political economies and physical surroundings lead to a similar portfolio of policies and measures being applicable, in many cases, to most, as will be shown.

The following section produces accounts of national policies, measures and instruments in the areas of mitigation (Sections 3.2.1-7), participation in the CDM (3.2.8) adaptation and response measures (3.3), and other areas of climate action (3.4). Understanding the full scope of government policies that relate to tackling climate change requires an examination of both de facto climate policies and those with other primary objectives (such as) energy security and pollution) but with consequences for emissions.$^{197}$ The section therefore adopts a broad understanding of climate policy by analysing, on the one hand, both 'explicit' (called by the governments as such) and 'implicit' (with climate policy impact) policies and measures and, on the other, both 'direct' (targeting emissions/adaptation) and 'indirect' (with indirect impacts) policies and measures relating to climate action. The following subsections seek to answer the question of how climate policy is currently defined in the GCC, and particularly in the three states examined. The analysis below proceeds based on the framework outlined in Sections 2.2-4.

\subsubsection{Economy-wide Policies, Measures and Instruments}

Whilst the drivers and institutions for low-emission development may exist, and there is growing interest in the opportunities for emission avoidance supported by international project-based mechanisms, clear, holistic national policies, strategies and frameworks for action still remain undefined. In 2013, none of the GCC states had in place quantified economy-wide policies for curbing emission growth, such as emission or emission/energy intensity targets. Country-wide adaptation strategies or policies had not yet been drafted either.

At the time of writing, economy-wide mitigation strategies were being developed in two states: in the UAE, the emirate of Abu Dhabi is developing a High Level Strategy and Action Plan for Climate Change Mitigation and Adaptation for 2014-2018. ${ }^{198}$ The strategy is developed through a government-level multi-stakeholder process, with the leadership of Environment Agency - Abu Dhabi

\footnotetext{
197 IEA, Redrawing, 18

${ }^{198}$ EAD, 'EAD and Key Government Partners Helping to Shape Abu Dhabi's Climate Change Strategy', press release (8 October 2013).
} 

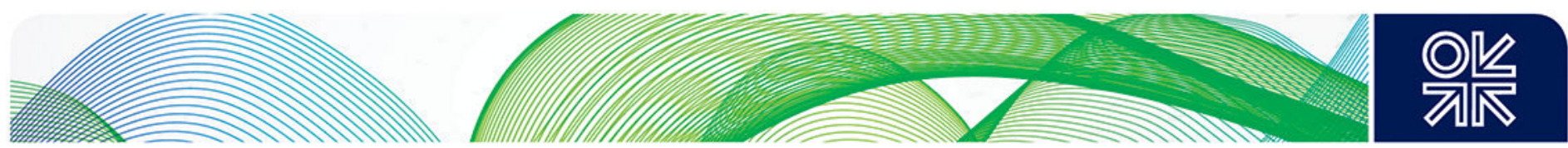

(EAD). Mitigation priorities have been outlined as low-carbon transition and development in key sectors (energy and utilities, transport, buildings and infrastructure, and industries) and energy demand management. Priorities on the adaptation side will include building the climate resilience of the economy and natural and human capital. In addition, the UAE is working on a federal Green Growth Strategy, the action plan for which is expected to be launched in early $2014 .{ }^{199}$ The strategy, which is being developed through multi-stakeholder consultations with the public and private sectors, is expected to include sectoral targets, which could have important synergistic impacts for emissions trajectories. (See also Section 4.3.3.) Qatar's national communication describes a national plan for energy efficiency, optimisation and resource utilisation, QEERU, which includes aims related to expanding Qatar's CDM portfolio and increasing energy efficiency, ${ }^{200}$ but information on an actual implementation plan was not available. No such published plans or strategies were found for Saudi Arabia, but officials have described a low-emission development strategy that includes switching to natural gas, energy efficiency, carbon management and related R\&D, and renewable energy. ${ }^{201}$

Overall, the two of the three GCC states define their 'explicit' mitigation policies and measures in narrow terms, with the UAE as the exception: In its national communication from 2012, the UAE lists the following mitigation measures: deployment of clean energy technologies; intellectual property development in clean energy, including CCS; and renewable energy and energy efficiency aid programmes in developing countries. The UAE considers the Masdar Initiative and its Masdar City as the vanguard in this area, aiming to become a renewable energy-powered clean tech hub for research, development, testing, and implementation of GHG reduction technologies. ${ }^{202}$ Saudi Arabia's national communication from 2011 on the country's steps to implement the UNFCCC notes 'a keen interest at the national level' in renewable energy development and rational use of energy', and describes several, mostly small-scale, initiatives dating back as far as the 1990s, in the areas of rational use of energy, renewables, carbon capture and management, solid waste management, sustainable urban development and green buildings, transportation, awareness and R\&D. ${ }^{203}$ Qatar's communication stresses that mitigation initiatives are pursued as long as they do not hinder economic growth and describes its LNG exports as a major mitigation contribution. National actions mentioned include: gas flaring reductions; funding to R\&D and clean tech funds; and public transport systems. ${ }^{204}$ However, as the following sections will show, the scope of existing sectoral mitigation plans and actions is significantly broader in all three states.

\subsubsection{Energy Supply}

Climate change mitigation policies, as defined above (Section 3.2), can be examined in three areas in the GCC context: energy efficiency; fuel switching and renewable energy; and carbon capture and storage. In the area of energy efficiency, Qatar's current five-year National Development Strategy sets 13 efficiency targets for water and energy, which are tied to existing plans in the sector. ${ }^{205}$ On the supply side, these include: technical efficiency improvements; water network leak reductions; and expansion of treated sewage effluent networks, whereas on the demand side measures include: advancing the adoption of energy-saving technologies and phased removal of electricity, water and fuel subsidies. Qatar is also establishing an independent water and power regulator, which is expected to lead in efficiency improvements in the sector. In addition, Qatar's development strategy has a sectoral intensity goal consisting of halving the share of gas flaring of energy produced by 2016 , from the 2008 levels of $0.0230 \mathrm{bcm} / \mathrm{Mt}^{206}$

\footnotetext{
${ }^{199}$ Abdul Kader, 'UAE to Announce'; Preeti Kannan, 'UAE Devises Green Strategy to Unify Existing Policies', The National (17 December 2013).

State of Qatar Ministry of Environment, $1^{\text {st }} \mathrm{NC}, 40$.

${ }^{201}$ Personal e-mail interview with Saudi Arabia's climate negotiation team members, 30 December 2013.

202 UAE Ministry of Energy, $3^{\text {rd }}$ NC, xv. The UAE's strategy for implementing the UNFCCC in terms of mitigation is outlined in less ambitious terms as developing a full national GHG inventory. 

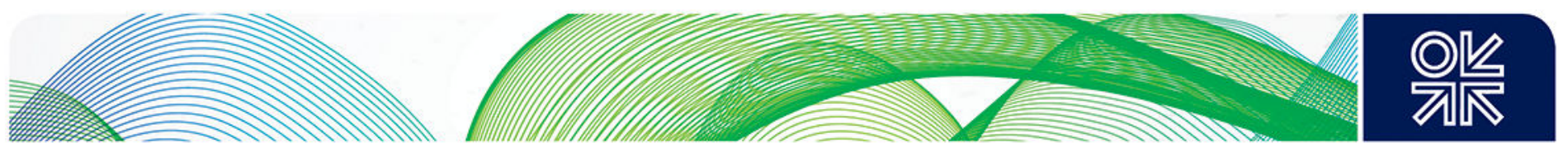

Saudi Arabia is placing heavy emphasis on energy efficiency: the Saudi Energy Efficiency Center (SEEC), established in 2010 and currently based at KACST, is working with the development and implementation of policies and regulations, awareness-raising, pilot projects and stakeholder coordination. ${ }^{207}$ Since 2012, the SEEC has been developing the Saudi Energy Efficiency Programme (SEEP), which comprises energy efficiency goals and initiatives and has activities in four areas: regulation (including an energy conservation law), information systems, capacity development and awareness-raising. The plan also includes efficiency objectives for the buildings, industry and transportation sectors (discussed below). A previous iteration of the SEEP, the National Energy Efficiency Programme (NEEP), from 2008, included two quantitative goals in the electricity sector: cutting electricity intensity by $30 \%$ between 2005 and 2030 , and halving the growth in peak demand by 50 percent compared to $2000-2005$ levels. ${ }^{208}$

Work on energy efficiency in the UAE is carried out by the individual emirates. The Dubai Integrated Energy Strategy 2030, from 2011, includes aims and measures for energy efficiency and reducing consumption, such as energy pricing, regulation and technology deployment. ${ }^{209}$ Dubai's utilities authority DEWA has implemented measures to increase generation efficiency and reduce power grid and water supply system losses ${ }^{210}$ On the demand management side, given the emirate's scarce energy resources, Dubai has introduced a progressive two-prong tariff system for electricity, with a slab-based component and a fuel surcharge component that adjusts to the actual price incurred by the authority. Slab tariffs are also applied to water utilities. ${ }^{211}$ Dubai has also set a quantitative energy consumption reduction target of 30 percent by 2030 in relation to business-as-usual projections ${ }^{212}$ In 2008, Abu Dhabi set up a demand side management working group, coordinated by its Executive Affairs Authority that has studied the potential for savings in non-industrial sectors of power and water consumption (12bcm of natural gas/year in 2020) and made recommendations, which include codes and standards for construction and tariff reforms. ${ }^{213}$

With regard to decarbonising the energy mix, the three states examined have adopted a number of quantitative policy goals: the emirate of Abu Dhabi, with a current renewable energy capacity of 115 MW, has set a renewable target of 7 percent of installed power production capacity by 2020, which according to Krane equals to around 2.5 percent of production. ${ }^{214} \mathrm{Abu}$ Dhabi is also aiming to have four 1.4 GW nuclear reactors online in 2017-2020 which, according to the government, will yield up to $12 \mathrm{MtCO}_{2}$ in yearly emission avoidances. ${ }^{215}$ By 2030, the emirate of Dubai is aiming at diversifying its power mix to solar (5 percent), nuclear (12 percent), and coal with CCS (12 percent), with the rest coming from natural gas. ${ }^{216}$ The solar plans of the emirate, which has a solar capacity of $13 \mathrm{MW},{ }^{217}$ include a $1 \mathrm{GW}$ solar park and deployment of rooftop solar (with a $2.5 \mathrm{GW}$ potential identified) by $2030 .^{218}$ At a national level, the UAE's Energy Minister has mentioned the goals of 25 percent of power generation from nuclear energy by 2020 and a 2.5 GW renewables capacity, presumably a sum of Abu Dhabi's and Dubai's plans. ${ }^{219}$

\footnotetext{
207 SEEC took over the National Program for Administration and Rationalization of Power Consumption, established in 2003. Presentation at Chatham House workshop Approaching COP18.

${ }^{208}$ ABB, Saudi Arabia Energy Efficiency Report (April 2012), 2.

${ }^{209}$ Dubai Global Energy Forum, 'Dubai Supreme Council of Energy’ [http://www.dgef.ae/sce.aspx], accessed in October 2013.

Construction Week Online, 'DEWA Succeeds in Cutting Grid Power Losses' (24 September 2013).

211 Oxford Business Group, The Report: Dubai 2013 (Dubai, OBG, 2013), 197.

212 UNDP and Dubai Carbon, State of Energy Report: Dubai 2014 (Dubai: Dubai Supreme Council of Energy, 2013), 10.

${ }^{3}$ Bruce Smith, 'Demand Side Management - Plans and Challenges in Abu Dhabi', presentation, May 2012.

214 Jim Krane, 'Renewable Energy: Hype and Reality', Aspenia International, No. 59-60 (2013), 85.

${ }^{215}$ Emirates Nuclear Energy Corporation, 'Construction of the UAE's Second Nuclear Power Plant Gets Underway', press release, 28 May 2013.

${ }^{216}$ Current shares are: 99\% natural gas and 1\% diesel oil. Oxford Business Group,: Dubai 2013, 197.

${ }^{217}$ Karin Kloosterman, 'Dubai Opens 13 MW Solar Plant, the Largest PV Plant in Mideast', Green Prophet (23

October 2013)

${ }^{218}$ WAM, 'Dubai's Energy Growth Set to Be 4-5\% by 2030', Emirates 24/7 (24 October 2012).

${ }^{219}$ Khaleej Times, 'UAE Diversifying Resources' (15 October 2013).
} 

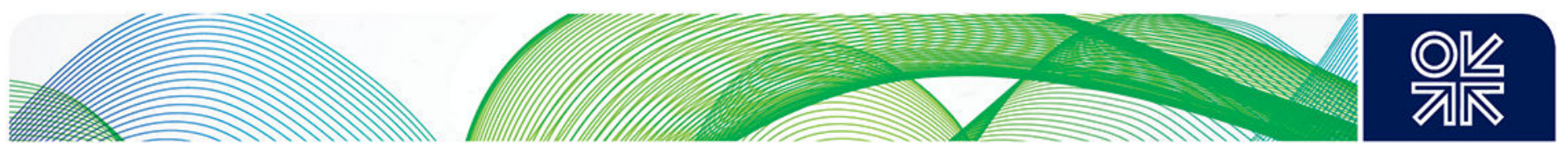

In Saudi Arabia, the high domestic oil consumption $(2.8 \mathrm{~m}$ barrels/day and over a quarter of total production in 2011) and related opportunity costs are acting as drivers for energy policy measures with parallel emissions reduction benefits. ${ }^{220}$ According to one estimate, total domestic energy demand is expected to grow from $3.4 \mathrm{mboe} / \mathrm{d}$ to $8.3 \mathrm{mboe} / \mathrm{d}$ by $2028 .{ }^{221}$ Alongside the energy efficiency policies described above, the King Abdullah City for Atomic and Renewable Energy (K.A.CARE), established in 2010, is working on a plan to increase the share of renewable and nuclear energy to 50 percent of generated electricity by 2032. The following capacities have been proposed for installation: of $17.6 \mathrm{GW}$ of nuclear, $41 \mathrm{GW}$ of solar (39\% of which PV and the rest CSP), $9 \mathrm{GW}$ of nuclear, $3 \mathrm{GW}$ of waste-to-energy and $1 \mathrm{GW}$ of geothermal energy. ${ }^{222}$ In the more immediate term, the King Abdullah Initiative for Solar Water Desalination aims to power all desalination plants in the country with solar energy, by 2020 . Its first phase consists of a $10 \mathrm{MW}$ desalination plant with a capacity of $30,000 \mathrm{~m}^{2} / \mathrm{d}^{223}$ Saudi Arabia's current renewables capacity is at $6 \mathrm{MW} .{ }^{224}$

With Qatar's natural gas resources and their availability for domestic use, and with the existing power subsidies (as in other GCC states), economic incentives to switch to cleaner energy sources, and in particular solar, are not as high as elsewhere in the region. Lack of institutional coordination is another characteristic impacting coordinated deployment. In 2012, Qatar's Ministry of Energy and Industry announced the launch of a $200 \mathrm{MW}$ solar energy programme, equal to approximately 2 percent of total demand. ${ }^{225}$ In addition, the 2013 Qatar National Food Security Plan, developed by the Qatar National Food Security Programme, recommends the installation of 700-800 MW in solar PV capacity by 2018 , developed through public-private partnerships, to meet the energy requirements of the projects proposed in the plan. This capacity could also be used to fulfil Qatar's pledge to organise a carbon neutral FIFA football world cup in 2022. In parallel, Qatar Foundation has announced a national commitment of $1 \mathrm{GW}$ over the next decade, presumed to be an aggregate of the projects mentioned above. ${ }^{226}$

A major switch in the GCC from oil towards natural gas in the power and water sector already occurred in the 1990s in Qatar, driven by an energy exports diversification strategy, and elsewhere starting in the 2000s, driven by rising international oil prices. Saudi Arabia, which does not import or export natural gas and generates nearly two-thirds of its electricity from oil, has announced it will develop shale gas from its unconventional gas resources, estimated at more than twice the country's conventional resources. ${ }^{227}$ Studies on the net impact on emissions of switching to shale gas have yielded unclear results: whilst switching to natural gas may reduce emissions, upstream emissions from hydraulic fracturing and possible increases in oil exports increase them. ${ }^{228}$

Carbon capture and storage (CCS) is considered in the GCC as a 'win-win' technology, with expected benefits in enhanced oil/gas recovery (EOR/EGR), emission reductions, and monetization of these reductions through the CDM. It is also broadly seen as the only way to continue using fossil fuels in a carbon-constrained world. With the cost of capture as one of the main obstacles for broader deployment world-wide, in addition to fledgling regulation and questions over safety and liability, one proposed option would be to pass the added cost to consumers, which would also incentivise conservation. ${ }^{229}$

\footnotetext{
${ }^{220}$ Glada Lahn and Paul Stevens, Burning Oil to Keep Cool: The Hidden Energy Crisis in Saudi Arabia (London: Chatham House, 2011), 2 and passim.

${ }^{1}$ K.A.CARE, 'Sustainable Energy' [http://www.kacare.gov.sa/en/sustainable-energy/sustainable-energy], accessed in October 2013.

222 lbid.

${ }^{223}$ Construction Week Online, 'Saudi Solar-Powered Desal Plant Ready by Year-End' (27 August 2013).

${ }^{224}$ Krane, 'Hype and Reality', 85.

${ }^{225}$ Ministry of Energy and Industry (Qatar), 'Qatar Launches Project to Produce Electricity from Solar in Parallel with the COP18' [http://www.mei.gov.qa/news-en/Qatar-launches-project-to-produce-electricity-from-solar-inparallel-with-the-COP18/67/], accessed in October 2013.

${ }_{226}$ Personal correspondence with government stakeholder representative, December 2013

${ }_{227}^{22}$ Arab News, 'Kingdom to Use Shale Gas for Electricity Generation' (15 October 2013).

${ }^{228}$ See e.g. J. Broderick and K. Anderson, Has US Shale Gas Reduced $\mathrm{CO}_{2}$ Emissions? Technical Report

(Manchester: Tyndall Centre for Climate Change Research, 2012).

${ }^{229}$ Presentation at Chatham House workshop Approaching COP18.
} 

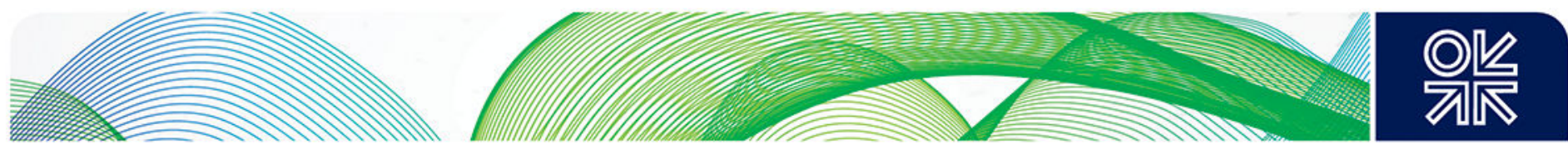

So far, two GCC states are working on CCS pilot projects and deployment: the first project was initiated in 2009 in Abu Dhabi and is working on enhanced oil recovery (EOR). ${ }^{230}$ In late 2013, Masdar and ADNOC signed a joint venture agreement to construct a US $\$ 123$ million $\mathrm{CO}_{2}$ compression facility and a $50 \mathrm{~km}$ pipeline between an Emirates Steel facility and oil fields in Abu Dhabi by 2016. The EOR project is expected to prevent up to $800 \mathrm{kt} / \mathrm{CO}_{2} /$ year. ${ }^{231}$ Saudi Aramco is working on CCS applications through a Carbon Management Technology Roadmap, comprising research and development and pilot projects in the areas of: capture in fixed sources and reduction in mobile sources (vehicles, trains and marine vessels); industrial applications (including polymers, chemicals and construction materials); storage; and using $\mathrm{CO}_{2}$ for EOR. ${ }^{232}$ The company plans to implement an EOR demonstration project in 2014, the rationale of which, in the absence of an economic motive, is said to be environmental. ${ }^{233}$ In Qatar the Carbonates and Carbon Storage Research Centre, established in 2008 , works with R\&D, including building national capacity. ${ }^{234}$

Whilst the GCC states are working on an expansive portfolio of emissions reduction-related policies and measures, on both supply and demand sides, a number of options still remain unexplored, partly because some touch upon issues perceived as politically sensitive. Most importantly, given the GCC states' social contract whereby oil and natural gas have long been considered citizens' endowments, ${ }^{235}$ utility prices continue to remain too low to encourage energy and water saving and efficiency, and are in some cases even below the level of cost recovery. Also, none of the three states are currently employing emission and energy taxes, (tradable) emissions permits, or emissions reductions for major point source emitters. Whilst in relation to enabling environments for renewables, Abu Dhabi offers power purchase agreements and Saudi Arabia is reported to be planning feed-intariffs for renewables for $2015,{ }^{236}$ domestic utilities pricing does not yet encourage their deployment on a market basis. Furthermore, consumer subsidies to fossil fuels still far outnumber those provided to renewables: according to IEA estimates, in 2010, the former constituted 9.8 percent of Saudi Arabia's GDP (or US\$44bn), and 6, 5.8 and 3.2 percent of those of the UAE Kuwait and Oman, respectively. In the three latter countries, per capita subsidies were estimated at US $\$ 2,400-2,800{ }^{237}$

\subsubsection{Buildings}

Buildings in the Gulf, on average, are energy inefficient: for example, in Saudi Arabia, 70 percent of homes are not insulated. ${ }^{238}$ Also, the use of air conditioning is the major source of energy use (and emissions): in Qatar, it accounts for up to 70 percent of energy consumption in buildings. ${ }^{239}$ The most visible form of mitigation-relevant measures employed in the GCC are the green building codes, which incorporate a number of energy efficiency/saving and alternative energy technologies discussed in Section 2.2.3. Other areas where the three states are taking measures include appliance standards and community-based sustainable design. Some behavioural change 'experiments' have also been undertaken. (Electricity and water use more broadly, including pricing, are discussed above, in Section 3.2.2.)

\footnotetext{
230 IISD-RS, COP 18 side event on 'Global Update on Carbon Capture and Storage (CCS) and Regional Project Perspectives', report (1 December 2012).

${ }^{231}$ BusinessGreen, 'Masdar Digs Deep for Middle East's First Carbon Capture Project' (14 November 2013)

${ }^{232}$ Ali A. Al-Meshari, 'Saudi Aramco's Efforts in Carbon Management', presentation, May 2013.

233 IISD-RS, COP18 side event on 'Carbon Management in GCC Countries', report (6 December 2012).

234 IISD-RS, COP18 side event on 'Global Update on CCS'.

${ }^{235}$ Bassam Fattouh and Laura El-Katiri, Energy Subsidies in the Arab World, Arab Human Development Report Research Paper Series (UNDP Regional Bureau for Arab States, 2012), 15, 29.

${ }^{236}$ Adrian Creed and Amir Kordvani, 'Recent Developments in the Renewable Energy Sector in MENA and Central Asia' (Clyde \& Co., 23 September 2013).

${ }^{237}$ Presentation at Chatham House workshop Approaching COP18.

${ }^{238}$ Naif M. Alabbadi, 'Energy Efficiency Potential in the Building Sector', presentation for the Saudi International Advanced Materials Conference, Riyadh, 3-4 December 2012.

${ }^{239}$ Qatar Cool, presentation in Qatar-Korea Renewable Energy Seminar, Doha, October 2011.
} 

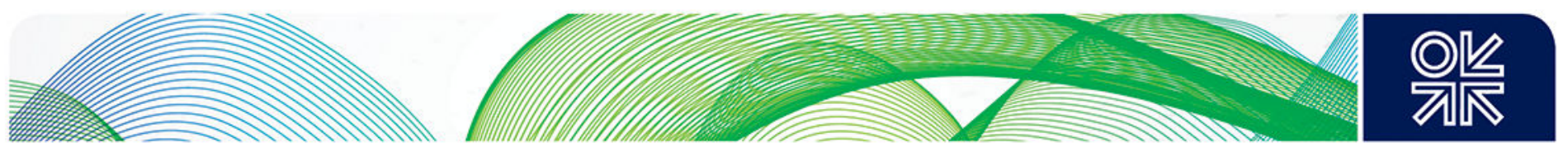

In the UAE, Abu Dhabi has launched its own sustainable building code, Estidama, some elements of which became compulsory for all new buildings from 2010. ${ }^{240}$ Abu Dhabi government is also designing a comprehensive cooling plan, which according to press sources will aim to reduce emissions related to air conditioning by $10 \mathrm{MtCO}_{2} \mathrm{e}$ by $2025 .{ }^{241}$ In Dubai, an emirate-wide green building 'code' was launched as early as in 2007 , but is yet to be made compulsory. A number of government entities, companies and buildings are, however, applying the US LEED rating system. The Dubai Municipality is also working with a number of sustainability projects, including applying LED lighting solutions the municipality's 262 buildings and cutting water and electricity consumption by 20 percent over a five-year period. ${ }^{242} \mathrm{~A}$ local think tank in Qatar has developed the Global Sustainability Assessment System (GSAS, formerly QSAS), which has been incorporated into the national construction standards, with plans to eventually making it compulsory. ${ }^{243}$ Unlike Estidama, which is an adaptation of the LEED system, GSAS has been developed specifically for the local conditions. Saudi Arabia has not developed its own green building code, but nearly 700 buildings are said to be working with the LEED system, some of them having already received a rating, including, the campuses of Princess Noura Bint Abdulrahman University in Riyadh, and the King Abdullah University for Science and Technology near Jeddah. ${ }^{24}$

Saudi Arabia's energy efficiency programme SEEP has focused its efforts in the buildings sector in four areas: air conditioner, insulation, lighting and the national building code. ${ }^{245}$ In these areas it has validated a consumption baseline, signed memoranda of understanding on energy efficiency guidelines with major entities, including SABIC and Saudi Aramco, and issued updated standards and regulation for enhanced performance.

The UAE uses a national star-rating labelling system for household appliances, air conditioning systems and lighting. The system is coded in legislation and in its first phases of implementation. By 2016, annual savings achieved through applying mandatory ratings for air conditioning units alone are estimated at US $\$ 109 \mathrm{~m} .{ }^{246}$ Saudi Arabia's energy labelling programme includes air conditioners and major household appliances. ${ }^{247}$ Qatar has recently set an energy efficiency standard for new air conditioners. ${ }^{248}$ In the area of water use, with the aim of cutting the consumption of desalinated water by half, Abu Dhabi is hoping to install water saving devices in all taps in the emirate, through voluntary adoption, by $2030 .^{249}$

Whilst all three states boast examples of sustainable design applied at community level, Abu Dhabi's Masdar City, a community development of $6 \mathrm{~km}^{2}$ established in 2008 (still in its initial construction phases in 2013), is the most famous one: aiming to be fully powered by renewables and incorporating numerous aspects of sustainable living, Masdar City has so far inaugurated half a dozen sustainable buildings ${ }^{250}$ In Saudi Arabia, the campus of King Abdullah University of Science and Technology holds LEED platinum (the highest) rating. The campus design incorporates daylighting and natural ventilation features, and solar-enabled rooftops, recycled building materials, and water conservation,

\footnotetext{
${ }^{240}$ Estidama, 'Pearl Building Rating System' [http://estidama.org/pearl-rating-system-v10/pearl-building-ratingsystem.aspx], accessed in October 2013.

Binsal Abdul Kader, 'Efforts to Control Abu Dhabi's High Rate of Per Capita Carbon and Water Footprints', Gulf News (28 July 2013).

UAE Interact, 'Dubai Municipality Takes Further Step Towards Being Most Sustainable City in World with LED Lighting' (2 October 2013);

${ }^{243}$ Luomi, The Gulf Monarchies and Climate Change, 191-2.

${ }^{244}$ CA News Network, 'KSA is LEED-ing the Way to a Sustainable Design of Undergoing Building Projects', Construct Arabia (5 March 2013).

${ }^{245}$ Naif M. Alabbadi, 'Saudi Energy Efficiency Center', presentation at the AFED $6{ }^{\text {th }}$ Annual Conference, Sharjah, 28-29 October 2013

${ }^{246}$ WAM, 'Energy Rating Labels to Be Displayed on All UAE Appliances', UAE Interact (9 July 2013).

247 Intertek, 'Energy Efficiency Label Testing - Kingdom of Saudi Arabia (KSA)'

[http://www.intertek.com/appliances-electronics/energy-efficiency/ksa-label/], accessed in December 2013

Kahramaa, 'New Qatari Standards for AC Energy Efficiency', press release (4 August 2013).

${ }^{249}$ Ryan Carter, 'New Taps to Curb Abu Dhabi Water Usage', The National (18 April 2013).

250 Masdar City, 'Frequently Asked Questions' [http://masdarcity.ae/en/110/frequently-asked-questions/], accessed in October 2013.
} 

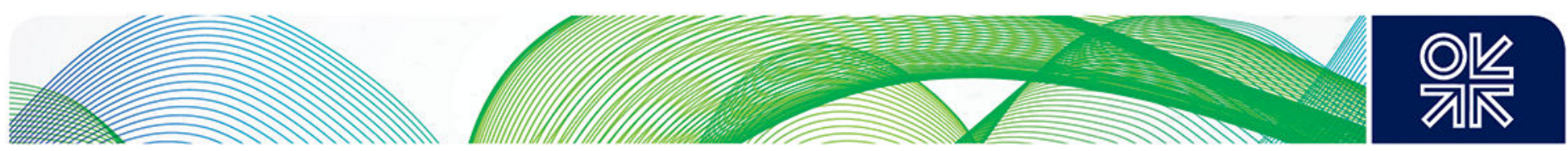

among others. ${ }^{251}$ In Qatar, new buildings in Education City, home of several Western universities, are sustainably designed and a number hold LEED ratings, including the Qatar National Convention Centre and two residence halls for students. ${ }^{252}$ District cooling, a sustainable community-level technology, is applied in 47 high-rise buildings in Doha's central West Bay district and the Pearl island development project. ${ }^{253}$ Dubai's rooftop solar plans, as mentioned above, include passing of supportive legislation and the possibility of feed-in-tariffs. ${ }^{254}$

Abu Dhabi has pioneered with several behavioural experiments, including the distribution of watersaving devices to 55,000 homes (after a study found that water desalination results in emissions of 4$9 \mathrm{MtCO}_{2} \mathrm{e} /$ year $^{255}$ ) and tens of thousands energy-efficient light bulbs every 20 of which installed is said to equal removing all the emissions from one car on the road. ${ }^{256}$ Since 2012 , it has also included information on the full production cost of electricity and water in utilities bills. ${ }^{257}$ Both Masdar City in Abu Dhabi and Education City in Doha have engaged student residents in behavioural change-related experiments in the area of sustainable living. ${ }^{258}$

Although the UAE and Qatar in particular are taking numerous emission-reducing measures in the buildings sector, including building codes, appliance standards and efficiency and saving campaigns, the scope of implementation is still extremely narrow and epitomised by green prestige projects, whilst demand side management programmes are characterised by the use of soft, persuasive instruments (discussed in more detail in Section 3.2.7 below). Retrofitting of buildings, and the crucial idea of fullcost utilities pricing have only in the recent years appeared on the GCC governments' radars.

\subsubsection{Manufacturing and Construction}

Whilst emissions originating from oil production and refining activities are treated by the UNFCCC as energy supply-related, the manufacturing and construction sector category of energy-related emissions data from the WRI (see Section 3.1.2) includes iron and steel, petrochemicals, aluminium and construction industries, among others. As noted above, the energy-intensive industries in this sector have the greatest potential to increase energy efficiency.

Aggregated information on industry measures in the GCC is scarce but, according to expert sources, energy efficiency has been actively promoted by the management of the three countries' main petrochemicals (and refining) companies, supported by clustering of major industries in industrial cities with centralised energy and heat production facilities, such as Saudi Arabia's Jubail and Qatar's Ras Laffan. ${ }^{259}$ In a pioneering project to capture and reuse $\mathrm{CO}_{2}$, the Saudi Basic Industries Corporation (SABIC) is planning to build a carbon capture and utilisation (CCU) plant in Jubail that would capture and purify 1,500 tonnes of $\mathrm{CO}_{2}$ per day (roughly $500 \mathrm{ktCO}_{2}$ /year) from the company's ethylene plants for use in its petrochemical plants. ${ }^{260}$ In Abu Dhabi, a government plan, delayed by several years due to high cost, is to build a CCS network capturing and transporting $\mathrm{CO}_{2}$ from power sector and industrial emissions to oil reservoirs for EOR, with local steel and aluminium plants as anchor projects. ${ }^{261}$ An example of manufacturing industry energy conservation measures is that of

\footnotetext{
${ }^{251}$ KAUST, 'Sustainable Development' [http://www.kaust.edu.sa/about/sustainable/sustainable.html], accessed in October 2013

252 Luomi, The Gulf Monarchies and Climate Change, 193-4.

${ }^{253}$ Qatar Cool, 'Our Customers' [http://www.qatarcool.com/ourcustomers.php], accessed in October 2013. The UAE and Saudi Arabia too have areas connected to district cooling, networks.

${ }^{254}$ Florian Neuhof, 'Dubai Looks to Rooftop Solar Power Revolution', The National (13 May 2013).

${ }^{255}$ EAD and Emirates Wildlife Society-WWF, Heroes of the UAE - Water Fact Sheet (undated/2009).

${ }^{256}$ Vesela Todorova, 'Homes to Be Fitted with Free Water-Saving Devices', The National (21 May 2010);

'Shoppers Presented with Energy-Saving Light Bulbs', The National (9 August 2010).

${ }^{257}$ Laura Collins, 'The Real Cost of Water and Electricity Will Shock You', The National (7 April 2012).

${ }^{258}$ Vesela Todorova, 'Masdar Students' Energy and Water Use Monitored', The National (28 April 2011).

259 Luciani, Energy Efficiency Policies in the MENA, 3.

260 Reuters, 'Germany's Linde to Build Big Saudi Carbon Capture-and-Use Plant' (21 August 2013).

261 Global CCS Institute, 'The Global Status of CCS: 2013; Appendix E: Existing $\mathrm{CO}_{2}$ Transport Infrastructure' [http://www.globalccsinstitute.com/publications/global-status-ccs-2013/online/118026], accessed in November 2013
} 

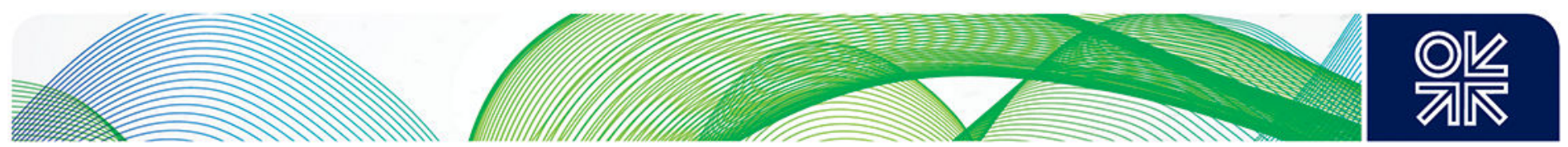

Dubal Aluminium (DUBAL), which has installed more efficient equipment, implements energy-saving measures in lighting and air-conditioning, and is participating in an initiative by the Dubai Supreme Council of Energy to diminish energy consumption overall. ${ }^{262}$ In Saudi Arabia, in a sector-wide approach, the SEEP is setting energy efficiency targets and enforcement mechanisms for new and existing plants in cement, steel and petrochemical industries and it is in the process of validating related baseline data. ${ }^{263}$

The three states are also at different stages of developing an industrial manufacturing base for renewables, given the comparative advantage brought by low energy costs for the industries: Qatar Solar Technologies is setting up a polysilicon plant in the industrial city of Ras Laffan, with an annual production capacity of 8,000t/year, to provide for global photovoltaic (PV) markets and, later, for domestic use. Exports are expected to commence in $2014 .^{264}$ In Abu Dhabi, Masdar PV, a branch of Masdar Initiative, owns a thin-film PV production company (established in 2009) in Erfurt, Germany. Lack of local demand led to the cancellation of plans to open a Masdar PV plant in Abu Dhabi, in 2011. ${ }^{265}$ Industry associations have been established in Saudi Arabia (Saudi Arabia Solar Industry Association, SABIA) and the UAE (Emirates Solar Industry Association, ESIA).

\subsubsection{Transport}

Existing transport-related mitigation policies and measures in the three countries can be examined under three broad categories: use of alternative fuels, public and freight transport, and urban planning. In addition, the Saudi SEEP is working on fuel economy standards, including reporting and labelling for low duty vehicles. ${ }^{266} \mathrm{~A}$ discussion on transport fuel price reform is still largely absent in most GCC states.

Compressed natural gas (CNG) is used in vehicles in the UAE and Qatar: Emirates Transport has opened four CNG vehicle conversion centres and, at the time of writing, had converted over 2,600 vehicles (including a fourth of Abu Dhabi's taxis), and plans include expanding the filling station network from 16 to 25 by $2014 .^{267}$ In 2012, Qatar Petroleum opened a CNG fuelling station in Doha; in 2013, the project included 64 public transport buses, with an additional 12 buses equipped with a dual fuel system. ${ }^{268}$ Future plans are to run Qatar's entire public transport bus and tax fleet on CNG. ${ }^{269}$

With still mostly fledgling bus transport networks, the most visible public transport projects in the GCC are the metros. Currently, Dubai has the only operating metro system, inaugurated in 2009, and plans exist in Doha (2018), Riyadh (ca. 2018), and Abu Dhabi (2020). The three states are also building national railway networks that will be used for both freight and passenger transport, with links to a planned GCC railway.

Broadly speaking, alongside low fuel prices that fail to discourage the widely prevalent and heavy use of (large) passenger cars with low fuel efficiency, urban planning in the GCC cities does not encourage the use of public transport, walking or bicycling. Long distances to neighbourhood and other services, sparse and unreliable public transport networks, geared mainly at low-wage segments of the population, and lack of proper sidewalks and bicycle lanes act as the principal disincentives, alongside hot summer temperatures. Many existing urban master plans, however, incorporate environmental sustainability aspects: Plan Abu Dhabi 2030, for example, includes the goal of

\footnotetext{
262 DUBAL, 'Energy conservation at DUBAL' [http://www.dubal.ae/how-we-care/optimising-energyefficiency/energy-conservation-at-dubal.aspx], accessed in November 2013.

${ }^{263}$ Naif M. Alabbadi, 'Saudi Energy Efficiency Center'.

${ }^{264}$ Qatar Solar Technologies, 'Project Update' [http://www.qstec.com/about/project-update], accessed in

November 2013

265 Renewable Energy Focus, 'Masdar PV Abandons Plans for UAE Solar Manufacturing Hub' (13 January 2011).

${ }^{266}$ Naif M. Alabbadi, 'Saudi Energy Efficiency Center'.

${ }^{267}$ Anwar Ahmad, 'CNG Vehicle Conversion Centre to Open in Northern Emirates', The National (9 October

2013). In addition, in Dubai, some water taxis and buses are running on CNG.

${ }^{268}$ Ramesh Mathew, 'Mowasalat to Operate 63 more CNG buses'. Gulf Times (17 September 2013).

${ }^{269}$ Ramesh Mathew, 'Karwa Receives First CNG-Run Car', Gulf Times (30 April 2013).
} 

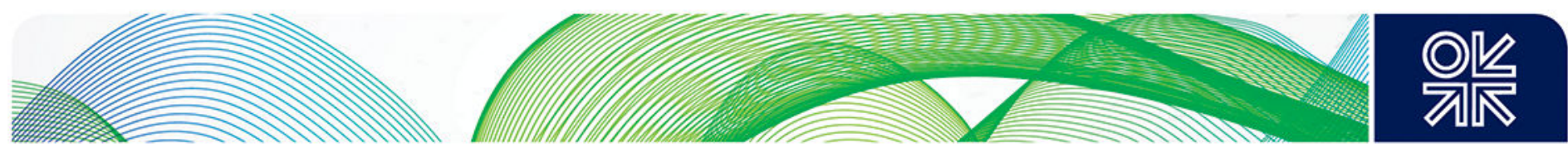

sustainable resource use, and Qatar's current five-year National Development Strategy aims at promoting sustainable urbanisation. ${ }^{270}$

\subsubsection{Fugitive Emissions}

Although data on fugitive emissions is somewhat problematic, as discussed in Section 3.1.2, the GCC states have paid attention to this area of emissions, as demonstrated by declining absolute amounts of gas flared since 2007 in Saudi Arabia, Qatar and Oman, according to data from the World Bank for top-20 'flarers'. ${ }^{271}$ In the three GCC states examined, the major national oil companies have either a zero flaring policy goal (ADNOC and Qatar Petroleum) or a flare minimisation plan (Saudi Aramco). Reflecting the large amounts of flaring already reduced up to 2007, ADNOC reports to have cut flaring by 78 percent since 1995and Qatar Petroleum by 59 percent since $2001 .{ }^{272}$ As shown in Table 6, all three states examined have developed CDM projects in gas flaring reductions, with the largest reductions, $2.5 \mathrm{MtCO}_{2}$ /year achieved by the Al-Shaheen project in Qatar. In addition, Qatar Petroleum is working on a US\$1bn project to significantly reduce gas flaring at LNG berths at the industrial city of Ras Laffan. ${ }^{273}$ Some estimates place the resulting reductions at $1.8 \mathrm{MtCO}_{2} /$ year. ${ }^{274}$ In Saudi Arabia, the Master Gas System, initiated in 1975 and expanded since 2000, feeds the country's industrial cities and has significantly reduced the share of flared associated gas.

\subsubsection{Other Sectors and Consumer Behaviour}

Both waste and agricultural emissions represent small shares of the GCC states' total emissions, each emitting less than $4 \mathrm{MtCO}_{2} \mathrm{e}$ in the five smaller states in 2009. In Saudi Arabia, too, the shares of the two sectors are also small ( 5 and 3 percent, respectively), but absolute emissions are more important: 23.6 and $13.1 \mathrm{MtCO}_{2} \mathrm{e}$, respectively. Perhaps the most significant mitigation plans in the agricultural sector are being devised in Qatar, where high food import dependency and nearly depleted groundwater resources are motivating the government to look into clean energy sources for producing desalinated water to increase domestic production in a sustainable manner, with a low carbon footprint.

In the waste sector, recycling campaigns are becoming more frequent in the GCC states, but a recycling industry is still largely nascent. ${ }^{275}$ For example in Qatar, of over 7,000 tonnes of waste generated daily in 2011, 92 percent ended up in landfills. Of this, 30 percent was domestic waste. According to the government, in 2011, a new waste management centre was expected to start processing 95-97 percent of domestic waste by recycling and waste-to-energy. A parallel aim is to increase recycling of non-domestic waste to 25 percent. $^{276}$

Four landfill gas capture and waste-to-energy projects in the UAE and Saudi Arabia have so far been registered under the CDM (see Table 6). Two landfill gas flaring reduction projects in Saudi Arabia will avoid nearly $500 \mathrm{ktCO} 2 \mathrm{e} / \mathrm{year}$. In Dubai, a project at the Al Ghusais landfill that receives 5,000 tonnes of waste daily is producing $1 \mathrm{MW}$ of electricity and avoiding $269 \mathrm{ktCO} 2 \mathrm{e} / \mathrm{year}{ }^{277}$ In the emirate of Ras Al-Khaimah a waste-to-energy project, running since 2009, has already issued $90 \mathrm{ktCO} e$ word of carbon credits.

Given the GCC states' high per capita $\mathrm{CO}_{2}$ emissions and ecological footprints, it is easy to make generalisations about consumer behaviour, some of which is misleading and some correct. Whilst the

\footnotetext{
270 Luomi, The Gulf Monarchies and Climate Change, 104, 167.

271 Global Gas Flaring Reduction Partnership, 'Estimated Flared Volumes'.

272 Luomi, The Gulf Monarchies and Climate Change, 116, 184.

273 Ibid., 184.

274 Personal correspondence with Axel Michaelowa, June 2012. Assuming that the project will recover

0.6Mt/LNG/year and that Qatari and Saudi LNG have a similar energy content.

${ }^{2}$ E.g. Yassir Amir, 'Govt Can Derive Income from Waste Recycling', Arab News (8 July 2013). Also, a regional recycling conference held in Dubai concluded that there were 'growth opportunities' in the paper and plastics recycling industries. Brian Taylor and Dan Sandoval, 'A Bright Future', Recycling Today (8 May 2013 ).

276 General Secretariat for Development Planning (Qatar), Qatar National Development Strategy, 225-6.

277 WAM, 'From Waste to Energy: Landfill Site Generates Electricity - First in the Region', (1 August 2013).
} 

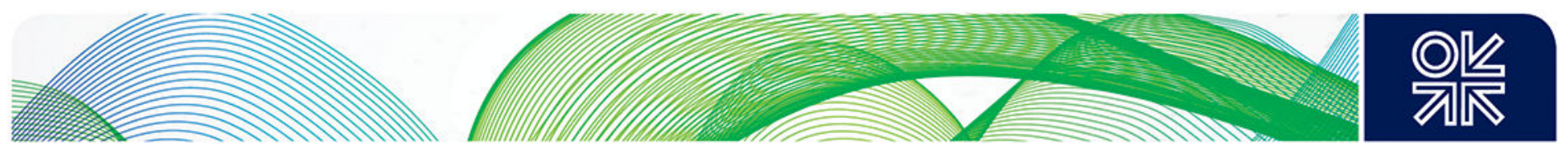

high per capita emissions in the smaller GCC states indeed are to a large extent attributable to small populations and large, energy-intensive fossil fuel-burning industries, the high ecological footprint rankings, which factor out export industries and factor in imports (see p. 52), point towards consumer lifestyles that are well over the global carrying capacity. Some natural resource consumption indicators are illustrative: in Qatar, a government document reported that, in 2009, Qatari nationals on average consumed 1,200 litres of water daily (presumably resulting from living in villas with large gardens but also from the free cost of water) whilst the rest of the population consumed $150 \mathrm{l} / \mathrm{d} .{ }^{278} \mathrm{~A}$ survey in Abu Dhabi, using data from 2005-2007, found that the average household (account) consumption was $41,000 \mathrm{kWh} /$ year $(71,000 \mathrm{kWh} /$ year for nationals and $26,500 \mathrm{kWh} / \mathrm{year}$ for expatriates, with the difference explained by the larger share of Emiratis living in villas. ${ }^{279}$ According to some estimates, the equivalent rates for the United States and United Kingdom were 11,700 kWh and $4,600 \mathrm{kWh}$, respectively. ${ }^{280}$ Waste generation rates are equally high, in a global comparison. ${ }^{281}$

Responding to the high and rising consumption levels, the governments of the three states examined have all initiated education and awareness campaigns, in some cases tailored at different target audiences. These efforts will be crucial in paving the way for inevitable, gradual price reforms in most GCC states in the coming years. Perhaps the broadest and most visible example has been the Heroes of the UAE campaign, led by the Emirates Wildlife Society (EWS-WWF) and the Environment Agency - Abu Dhabi (EAD), which targets electricity and water consumption in non-industrial sectors and has specific campaigns for schools, businesses and the general public. ${ }^{282}$ In Qatar, the utilities distributor Kahramaa initiated an electricity and water conservation campaign, Tarsheed, which aims at reducing per capita residential consumption by 20 percent and 35 percent, respectively, in 20122017, through education and awareness alone ${ }^{283}$ Similarly, in Saudi Arabia, the NEEP has conducted awareness-raising on energy conservation. ${ }^{284}$ Governments in many GCC states are starting to introduce environmental school curricula, and local branches of NGOs and IGOs are running eco school programmes. ${ }^{285}$

\subsubsection{Participation in UNFCCC Mechanisms}

With only three small and one large CDM project registered in the 2000s, the GCC states have become more active in participating in the mechanism over the past few years. In October 2013, as Table 6 shows, there were a total of 21 registered projects in the GCC, and a further eight in validation, none of which were in Bahrain. (Additionally, in 2008-2012, the registration of 12 projects based in the UAE submitted for validation was terminated at this stage. ${ }^{286}$ ) The GCC's registered projects amount to total emission avoidances of $4,803 \mathrm{ktCO}_{2} \mathrm{e} /$ year and, if approved, the projects still in validation will add to this up to $1,695 \mathrm{ktCO}_{2} \mathrm{e} /$ year. The total achieved reduction (approximately 6 Mt) is equivalent to 17 percent of Bahrain's total GHG emissions in 2010, or a mere 1 percent of those of Saudi Arabia (see Table 1). Basing on these figures it becomes clear that CDM in the GCC is not being fully exploited. Unfortunately, given the carbon credit (CER) price collapse in 2008 and their current oversupply, as well as the complex approval process, incentives for additional projects are not too favourable. ${ }^{28}$

In terms of sectors and types, the registered projects and those in validation, represent some variation, although clear patterns are visible: oilfield flaring reductions account for the largest absolute

\footnotetext{
${ }^{278}$ General Secretariat for Development Planning (Qatar), Qatar National Development Strategy, 218.

${ }^{279}$ Regulation and Supervision Bureau (Abu Dhabi), Report: Water and Electricity Consumption by Residential Customers (undated), 2.

${ }^{30}$ Data from Enerdata. Lindsay Wilson, 'Average Household Electricity Use Around the World'

[http://shrinkthatfootprint.com/average-household-electricity-consumption], accessed in November 2013.

${ }^{281}$ E.g. Vesela Todorova, 'UAE Working Hard to Reduce Waste', The National (5 July 2013).

${ }^{282}$ Heroes of the UAE website [http://www.heroesoftheuae.ae/en], accessed in November 2013.

${ }^{283}$ AMEinfo, 'Kahramaa Celebrates its First Tarsheed Anniversary' (27 April 2013).

${ }^{284}$ Kingdom of Saudi Arabia, $2^{\text {nd }}$ NC, 24

285 Including EAD's Sustainable Schools Initiative and the Eco-Schools programme in the UAE and Qatar.

${ }^{286}$ Reasons unknown. The projects were in Abu Dhabi, Ras Al-Khaimah and Dubai, in: flaring reduction, energy efficiency and PFC reduction. Fenhann, CDM Pipeline, 1 October 2013.

${ }^{287}$ See e.g. The Economist, 'Carbon Markets: Complete Disaster in the Making' (15 September 2012).
} 
reductions, with Qatar's Al-Shaheen (the first CDM project in the GCC) alone producing 17.5Mt of CERs in the first seven-year period. Another major area of reductions is landfill gas. A third of all projects, however, are in the area of energy efficiency, but with significantly lower contributions to emission reductions. Of the 29 projects, only four were in the area of renewable energy (PV and thermal solar and wind), with similarly minor contributions to reductions. Of the GCC states, the UAE has been the most active (17 projects), but Al-Shaheen, in Qatar, still generates the most reductions.

Table 6: CDM projects in validation and registered in the GCC countries, October $2013 .^{288}$

\begin{tabular}{|c|c|c|}
\hline Project (* if registered) & Type (start year for registered) & $\begin{array}{l}\text { Reductions }\left(\mathrm{ktCO}_{2} \mathrm{e}\right) \\
\text { and credits issued }\end{array}$ \\
\hline \multicolumn{3}{|l|}{ Bahrain } \\
\hline- & - & - \\
\hline Bahrain, total registered & 0 & 0 \\
\hline \multicolumn{3}{|l|}{ Kuwait } \\
\hline $\begin{array}{l}\text { Flare gas recovery, Mina Al-Ahmadi } \\
\text { refinery* }\end{array}$ & $\begin{array}{l}\text { Energy efficiency in industry, } \\
\text { petrochemicals (March 2013) }\end{array}$ & 54 (7 years) \\
\hline $\begin{array}{l}\text { Flare gas recovery, Mina Abdullah } \\
\text { refinery }\end{array}$ & $\begin{array}{l}\text { Fugitive emissions, oil field flaring } \\
\text { reduction (in validation) }\end{array}$ & 89 (7 years) \\
\hline $\begin{array}{l}\text { Central Gas Utilization Project, Wafra } \\
\text { field }\end{array}$ & $\begin{array}{l}\text { Fugitive emissions, oil field flaring } \\
\text { reduction (in validation) }\end{array}$ & 1,263 (7 years) \\
\hline Kuwait, total registered & 1 & $54 \mathrm{ktCO}_{2}$ e per year \\
\hline \multicolumn{3}{|l|}{ Oman } \\
\hline $\begin{array}{l}\text { Associated gas recovery and utilisation, } \\
\text { Block } 9^{*}\end{array}$ & $\begin{array}{l}\text { Fugitive emissions, oil field flaring } \\
\text { reduction (January 2013) }\end{array}$ & 775 (10 years) \\
\hline Waste management, Al Amerat* & $\begin{array}{l}\text { Methane avoidance, anaerobic } \\
\text { wastewater treatment (January 2013) }\end{array}$ & 18 (10 years) \\
\hline Oman, total registered & 2 & $793 \mathrm{ktCO}_{2}$ e per year \\
\hline \multicolumn{3}{|l|}{ Qatar } \\
\hline $\begin{array}{l}\text { Gas recovery and utilisation, Al- } \\
\text { Shaheen field* }\end{array}$ & $\begin{array}{l}\text { Fugitive emissions, oil field flaring } \\
\text { reduction (May 2007) }\end{array}$ & $\begin{array}{l}2,500 \text { ( } 7 \text { years), } \\
\text { Issued: } 3,178 \text { kCERs }\end{array}$ \\
\hline $\begin{array}{l}\text { Steam condensate recovery, Ras } \\
\text { Laffan Power Company, Doha }\end{array}$ & $\begin{array}{l}\text { Supply side energy efficiency, high } \\
\text { efficiency through waste heat use (in } \\
\text { validation) }\end{array}$ & 7 (7 years) \\
\hline Qatar, total registered & 1 & $2,500 \mathrm{ktCO}_{2}$ e per year \\
\hline \multicolumn{3}{|l|}{ Saudi Arabia } \\
\hline Landfill gas capture, Madinah* & Landfill gas, flaring (August 2012) & 139 (7 years) \\
\hline $\begin{array}{l}\text { Landfill gas capture, two landfills, } \\
\text { Jeddah* }\end{array}$ & Landfill gas, flaring (November 2012) & 355 (10 years) \\
\hline $\begin{array}{l}\text { Rooftop solar at parking lots, Al- } \\
\text { Dhahran* }\end{array}$ & Solar energy, PV (December 2012) & 10 (7 years) \\
\hline $\begin{array}{l}\text { Trigeneration system for a commercial } \\
\text { building, Makkah }\end{array}$ & $\begin{array}{l}\text { Energy efficiency in services, commercial } \\
\text { buildings (in validation) }\end{array}$ & 7 (7 years) \\
\hline Flare gas recovery, Safaniyah & $\begin{array}{l}\text { Fugitive emissions, oil field flaring } \\
\text { reduction (in validation) }\end{array}$ & 117 (7 years) \\
\hline Saudi Arabia, total registered & 3 & $504 \mathrm{ktCO}_{2}$ e per year \\
\hline
\end{tabular}

${ }^{288}$ Fenhann, CDM Pipeline, 1 October 2013. 


\begin{tabular}{|c|c|c|}
\hline \multicolumn{3}{|l|}{ United Arab Emirates } \\
\hline PV solar power plant, Masdar City, Abu & Solar energy, PV (June 2009) & 15 (7 years) \\
\hline Dhabi* $^{\star}$ & & Issued: 12 kCERs \\
\hline Landfill gas-to-energy, Ras Al- & Landfill gas, power (July 2009) & 40 (7 years) \\
\hline Khaimah* & & Issued: 90 kCERs \\
\hline Shams 1 solar power plant, Abu Dhabi* & $\begin{array}{l}\text { Solar, solar thermal power (September } \\
\text { 2011) }\end{array}$ & 175 (7 years) \\
\hline Waste heat-powered steam generation, & Supply side energy efficiency, high & 119 (10 years) \\
\hline Abu Dhabi* & $\begin{array}{l}\text { efficiency through waste heat use } \\
\text { (October 2009) }\end{array}$ & Issued: 189 kCERs \\
\hline $\begin{array}{l}\text { Energy efficiency in fuel gas } \\
\text { consumption at GASCO, Abu Dhabi* }\end{array}$ & $\begin{array}{l}\text { Energy efficiency in industry, } \\
\text { petrochemicals (April 2011) }\end{array}$ & 8 (10 years) \\
\hline $\begin{array}{l}\text { Distribution of } 789,540 \text { compact } \\
\text { fluorescent lamps to households. }\end{array}$ & $\begin{array}{l}\text { Energy efficiency in households, lighting } \\
\text { (October 2013) }\end{array}$ & 24 (10 years) \\
\hline \multicolumn{3}{|l|}{ Dubai* } \\
\hline PV solar power plant, Dubai* & Solar energy, PV (July 2013) & 13 (7 years) \\
\hline Wind farm, Sir Bani Yas, Abu Dhabi* & Wind energy (July 2014) & 20 (10 years) \\
\hline $\begin{array}{l}\text { Gas turbine efficiency improvement, } \\
\text { DEWA Chiller Station L, Dubai* }\end{array}$ & $\begin{array}{l}\text { Energy efficiency in services, A/C } \\
\text { (January 2013) }\end{array}$ & 27 (10 years) \\
\hline $\begin{array}{l}\text { Installation of new regenerative burners } \\
\text { at aluminium production plant, Dubai* }\end{array}$ & $\begin{array}{l}\text { Energy efficiency in industry, non-ferrous } \\
\text { metals (April 2013) }\end{array}$ & 10 (10 years) \\
\hline $\begin{array}{l}\text { Waste heat recovery at cement } \\
\text { company. Ras Al-Khaimah* }\end{array}$ & $\begin{array}{l}\text { Energy efficiency in own generation, } \\
\text { cement heat (October 2012) }\end{array}$ & 59 (10 years) \\
\hline Landfill gas recovery, Al Qusais, Dubai* & Landfill gas, flaring (November 2012) & 269 (7 years) \\
\hline Nour 1 PV solar power plant, Abu & Solar energy, PV (January 2014) & 64 (7 years) \\
\hline \multicolumn{3}{|l|}{ Dhabi $^{*}$} \\
\hline Flare gas reduction, Shah, Abu Dhabi* & $\begin{array}{l}\text { Fugitive emissions, oil field flaring } \\
\text { reduction (January 2013) }\end{array}$ & 109 (10 years) \\
\hline Biogas-based steam generation, Dubai & $\begin{array}{l}\text { Methane avoidance, manure (in } \\
\text { validation) }\end{array}$ & 10 (10 years) \\
\hline Biogas for power generation, Dubai & Landfill gas, composting (in validation) & 187 (7 years) \\
\hline $\begin{array}{l}\text { Waste heat recovery at cement plant, } \\
\text { Ras Al-Khaimah }\end{array}$ & $\begin{array}{l}\text { Energy efficiency in own generation, } \\
\text { cement heat (in validation) }\end{array}$ & 15 (10 years) \\
\hline UAE, total registered & 14 & $952 \mathrm{ktCO}_{2}$ e per year \\
\hline GCC, total registered & 21 & $4,803 \mathrm{ktCO}_{2} \mathrm{e}$ per year \\
\hline
\end{tabular}

In addition, Abu Dhabi's Masdar also developed CDM projects outside the region, in Uzbekistan (two natural gas pipeline leak reduction projects) and Egypt (a gas flaring reduction project), adding to a total of $1,630 \mathrm{ktCO} 2 \mathrm{e} /$ year. ${ }^{289}$ At the time of writing, no GCC state had announced a NAMA or an economic diversification initiative (see Sections 2.1.4 and 2.1.6).

\subsection{Status of Adaptation and Response Measures-Related Policy and Measures}

Similarly to the analysis above, albeit more concisely, this section examines emerging policy and actions relating to adaptation to climate change and its international response measures in the GCC states with a special focus on the United Arab Emirates, Qatar and Saudi Arabia.

Since the start of the oil era, the GCC states' urbanization and development has been based on adaptation to harsh natural environments. In this sense, the GCC states are perhaps among the best contemporary examples of successful adaptation: Qatar, for example, is sometimes anecdotally

${ }^{289}$ Fenhann, CDM Pipeline, 1 October 2013. 
referred to as the 'moon economy', given its absolute dependence on fossil fuels for all contemporary life-supporting functions, such as water, food, air conditioning, transport, and economic revenue. ${ }^{290}$ Some have noted that 'the Arab region's misfortune [of having a long experience with climate changerelated impacts] is also its policy advantage', ${ }^{291}$ and others that 'the environmental adaptive capacities throughout the Gulf states today are the most advanced in the world', albeit with a high attached economic and environmental cost. ${ }^{292}$ Indeed, in theory, and if environmental externalities are not counted, global demand for fossil fuels can indirectly (through export revenues) sustain the adaptive capacity of GCC states to the negative impacts of climate change as long as exports and revenues are sustained at levels high enough for the governments to break economically even and meet the citizens' expectations through sustaining socioeconomic development and prosperity. However, as discussed above, the GCC states are increasingly aware of the unsustainability of continuing on the current domestic energy and water consumption trajectories.

The contemporary concepts of climate change adaptation and resilience planning and policy have been explicitly introduced to the GCC only since the late 1990s and 2000s. Somewhat differently from mitigation activities - a more 'attractive' topic that many GCC states have been eager to promote and publicise - information on explicit and direct adaptation measures is principally communicated through the less visible national communications (NCs) to the UNFCCC. Implementation of adaptation and resilience measures is still nascent, with the most advanced plans and policies currently in place in the agriculture and water supply sectors and the least in the areas of coastal and infrastructure resilience, in particular with regard to integrated planning and management. ${ }^{293}$ In many cases, data and assessments required for informed policy-making are only starting to be accumulated.

According to its NC from 2012, the UAE is developing an adaptation strategy and policy with the aims of building adaptive capacity in key sectors, increasing ecosystem resilience, managing knowledge for policy and planning, and benefiting from synergies between mitigation and adaptation activities. ${ }^{294}$ Work is underway under a research programme for vulnerability and adaptation, focused on five priority areas of vulnerability, which include: regional climatic modelling; terrestrial and marine environment vulnerability assessments; water resource vulnerability assessment and management strategies; GIS-based sea-level rise modelling and a coastal vulnerability index for near-term planning; desalination impact study for the Gulf; long-term food price shock impact assessment; and a study on the positive health impacts of GHG reductions on human health. ${ }^{295}$ Saudi Arabia's NC from 2011 proposes adaptation measures, based on scenarios, in the areas of: sea-level rise (spatial planning, sand nourishment, dune management, salt marsh management, sea grass beds and sea dikes); water resources (more accurate hydro-meteorological projections; ecosystem protection and restoration; and demand management); desert ecosystems; and biodiversity. ${ }^{296}$ In the absence of a specific national adaptation strategy or policy, Qatar's NC stresses, as a first step, the need for highresolution climate models, followed by vulnerability assessments in targeted areas, socio-economic adaptation scenarios (linked to economic diversification), and finally national adaptation policies and plans. ${ }^{297}$ All three states are also working on expanding their water storage capacity.

In the area of foreign trade, a major vulnerability of the GCC states is their low self-sufficiency in agricultural and livestock products and high dependence on global food markets. All three examined GCC states are working on national food security programmes or strategies which have multiple aims, such as balancing domestic self-sufficiency and import dependency, securing imports, increasing

\footnotetext{
${ }^{290}$ First heard by the author from Jeremy Hunt, Doha, spring 2012.

291 John Waterbury, The Political Economy of Climate Change in the Arab Region, Arab Human Development Report Research Paper (UNDP Regional Bureau for Arab States, 2013), 26.

James A. Russell, 'The Persian Gulf: Bahrain, Iran, Iraq, Kuwait, Qatar, Saudi Arabia, the United Arab

Emirates, and Oman', in D. Moran (ed.), Climate Change \& National Security Washington D.C.: Georgetown

University Press, 2011), 170.

If infrastructure resilience plans and strategies exist, for example in the energy sector, these are not openly publicised.

94 UAE Ministry of Energy, $3^{\text {rd }}$ NC, 41

295 Ibid., 24-31.

${ }^{296}$ Kingdom of Saudi Arabia, $2^{\text {nd }}$ NC, $103-5,116$.

${ }^{297}$ State of Qatar Ministry of Environment, $1^{\text {st }}$ NC, 28, 35.
} 

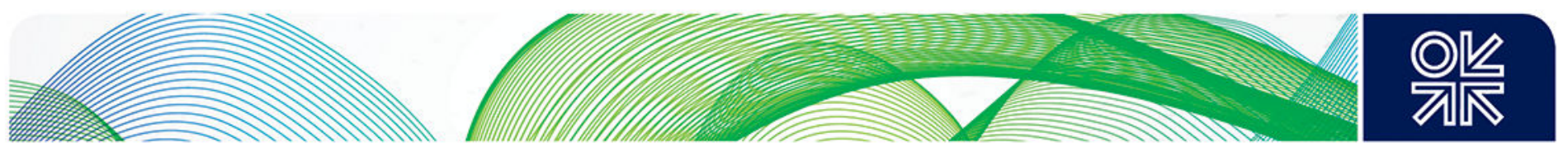

storage capacity, managing agricultural water demand, protecting natural water reserves, and sustainable agriculture. ${ }^{298}$ The impact of response measures is another trade-related issue. In the UNFCCC context, economic diversification has often been advocated by GCC states, principally Saudi Arabia, as a key means of increasing resilience to the negative impacts of climate response measures. Strengthening the resilience of the GCC economies can involve increasing overall economic resilience and reducing dependence on economic sectors that will suffer from the adverse impacts of response measures, in other words: hydrocarbon production, processing and exports and related energy-intensive industries. ${ }^{299}$ Saudi Arabia has also stressed the importance of including economic diversification in the sustainable development plans of developing countries, and called for assessing cost-effective options for economic diversification, such as capacity building and technology transfer. ${ }^{300}$ According to Saudi Arabia, resilience could be increased by (transfer of) technologies relating to: energy efficiency, cleaner fossil fuel technologies (CCS), non-energy uses of fossil fuels (e.g. petrochemicals), and alternative energy (solar). ${ }^{301}$ Notably, these technologies, if deployed broadly, would also serve to decarbonise the GCC states' energy supplies.

\subsection{Other Climate Change-Related Measures}

As defined in Section 2.4, other important areas that enable climate action include finance, technology development and transfer, and capacity-building, which include research and R\&D and international cooperative arrangements.

The CDM projects having been explored elsewhere in this study, it is interesting to note the increasing investments by GCC states, and the emirate of Abu Dhabi in particular, in clean energy companies and projects in Europe, the MENA region and globally, which have at least three kinds of primary motives: some projects have clear technology transfer objectives, such as Abu Dhabi's Masdar PV, a thin-film PV manufacturing plant in Germany established in 2008 and originally planned to build a second plant in Abu Dhabi. Others have foreign investments (and related financial returns) as their primary objective, such as Masdar's investments in the $630 \mathrm{MW}$ London Array offshore wind facility, the $120 \mathrm{MW}$ Torresol CSP solar plants in Spain, a $117 \mathrm{MW}$ wind farm in Jordan, and a memorandum of understanding with the British Green Investment Bank. ${ }^{302}$ Earlier investments include: an announcement by the four GCC OPEC states in 2007 to invest US $\$ 750 \mathrm{~m}$ in a clean petroleum technology and CCS research fund; Masdar's clean tech funds launched in 2006 and 2010, totalling US\$515m; and the Qatar-UK joint US\$400m clean energy investment fund from 2008 . Finally, and perhaps most interestingly, the UAE has financed energy projects in the Seychelles (6 MW wind farm) and Mauritania (15 MW solar plant), and (in response to the UN Secretary-General Ban Ki-moon's Sustainable Energy for All initiative) in Afghanistan and Tonga, which are most likely to be motivated by foreign policy-related aims, including foreign aid. ${ }^{303}$

Research and development and technology development on domestic soil is another area where the three GCC states have become active in recent years. Efforts in this area are linked to the GCC states' overall pursuit of knowledge-economy building. Saudi Arabia's 2011 national communication describes a large variety of R\&D efforts taken in four key areas presently and in the future: solar energy (including into pilot projects, building an industrial base for solar systems components), clean fuel production (including high octane compounds, fuel cell technologies, biotechnology applications), emission reductions (including CCS, emissions assessment), and water resources (including

\footnotetext{
298 See e.g. Qatar National Food Security Programme (QNFSP), [http://www.qnfsp.gov.qa/], accessed in December 2013; Ghazanfar Ali Khan, 'Pioneering Saudi Farm Techniques Bear Fruit', Arab News (23 September 2013).

${ }^{299}$ Adapted from: UNFCCC, document FCCC/SBSTA/2007/MISC.15, 30.

${ }^{300}$ E.g.: UNFCCC, document FCCC/SBSTA/2009/MISC.6, 11-2.

${ }^{301}$ UNFCCC, document FCCC/AWGLCA/2011/MISC.1, 86-7.

${ }^{302}$ Ed King, 'Masdar Aims to Boost Renewable Investments after London Array Success', RTCC (9 July 2013); John Everington, 'Masdar Invests in Jordan's First Major Wind Farm', The National (28 November 2013).

${ }^{3}$ King 'Masdar Aims'; Masdar Clean Energy, 'About Masdar Clean Energy'

[http://www.masdar.ae/en/energy/detail/masdar-clean-energy-who-we-are], accessed in December 2013.
} 
desalination) ${ }^{304}$ Table 7 presents a non-exhaustive list of research institutions in Qatar, Saudi Arabia and the UAE that work in areas related to climate change mitigation and adaptation.

Energy and other companies based in the GCC are also conducting important R\&D activities with commercial applications. Just two examples are aviation and CCS: some regional airlines fund R\&D into alternative aviation fuels and have performed test flights with biofuels and other alternative jet fuels, including Abu Dhabi's Etihad and Qatar Airways, ${ }^{305}$ whilst Saudi Aramco is studying cleanerburning transportation fuels and funds research on CCS, including in South Korea. ${ }^{306}$

Table 7: Research institutions with climate policy-relevant focus in three GCC states. ${ }^{307}$

\begin{tabular}{lll}
\hline Institution (est.) & Focal areas & Other remarks \\
\hline Qatar & Climate change impacts and & $\begin{array}{l}\text { Member of Qatar Foundation (QF), } \\
\text { in partnership with Potsdam } \\
\text { Institute for Climate Impact } \\
\text { (announced 2012) }\end{array}$ \\
& Research \\
\hline $\begin{array}{l}\text { Qatar Environment and Energy } \\
\text { Research Institute (2011) }\end{array}$ & $\begin{array}{l}\text { Air quality monitoring, PV and } \\
\text { water management technologies, } \\
\text { sustainable resource management } \\
\text { tools. Focus on Qatar. }\end{array}$ & Part of QF \\
\hline $\begin{array}{l}\text { Gulf Organization for Research \& } \\
\text { Development (2009) }\end{array}$ & $\begin{array}{l}\text { Energy and resource efficient and } \\
\text { environmentally responsible } \\
\text { building practices in Qatar and the } \\
\text { Gulf region. }\end{array}$ & $\begin{array}{l}\text { Member of QF, not for profit } \\
\text { subsidiary of Qatari Diar Real } \\
\text { Estate Investment Company }\end{array}$ \\
\hline $\begin{array}{l}\text { Qatar Carbonates and Carbon } \\
\text { Storage Research Centre (2008) }\end{array}$ & $\begin{array}{l}\text { Energy efficiency of oil and gas } \\
\text { recovery combined with GHG } \\
\text { reductions }\end{array}$ & $\begin{array}{l}\text { Member of QF, in partnership with } \\
\text { Imperial College London, Qatar }\end{array}$ \\
& $\begin{array}{l}\text { Petroleum and Shell. Offers a PhD } \\
\text { programme }\end{array}$ \\
\hline $\begin{array}{l}\text { Sustainable Energy Research } \\
\text { Laboratory, Texas A\&M University } \\
\text { at Qatar (university campus est. } \\
\text { 2003) }\end{array}$ & $\begin{array}{l}\text { Solar technologies, energy and } \\
\text { environmental policy. }\end{array}$ & Member of QF \\
\hline
\end{tabular}

\section{Saudi Arabia}

King Abdullah City for Atomic and

Renewable Energy (K.A.CARE)

(2010)

Basic research with potential to

meet national needs and

translation to commercialization in:

nuclear and renewable energy,

energy efficiency and cross-

functional technologies

Generation, storage and

conversion of renewable energies
Offers a PhD programme

Engineering Research Center,

King Abdullah University of

\footnotetext{
${ }^{304}$ Kingdom of Saudi Arabia, $2^{\text {nd }}$ NC, 24.

${ }^{305}$ Laurie Balbo, 'Ethihad[sic] Jet Uses Biofuels for Inaugural Home Run', Green Prophet (26 January 2012); Ivan Gale, 'Qatar Airways Heralds Biofuels Programme', The National (19 January 2010).

${ }^{306}$ Saudi Aramco, Saudi Aramco Environmental Stewardship (undated/2011 or 2012), 45; Oh Kyu-wook, 'Korean Institute and Saudi Aramco Agree to Establish CCS Research Centre', The Korea Herald (11 January 2013).

${ }^{307}$ Information has been gathered from the institutions' webpages in October-December 2013. Exceptions: i) Potsdam Institute for Climate Impact Research, "Promoting evidence-based decision-making": Qatar and PIK announce creation of climate change research institute', press release (5 December 2012). ii) Kingdom of Saudi Arabia, $2^{\text {nd }}$ NC, 40 .
} 

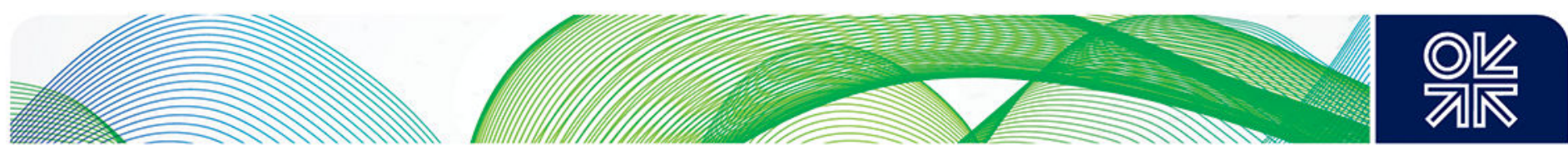

Science and Technology (KAUST)

(university est. 2009)

Clean Combustion Research

Pollutant control, climate change

Offers a MSc and PhD programme

Center, KAUST (university est. abatement, and sustainable fuel

2009)

usage in relation to fossil fuel

combustion

Research Centres of Excellence, various universities (est. 20072008) ${ }^{\mathrm{ii}}$

Pollution and waste, desalination, renewable energy, biotechnology, among others

At King Abdulaziz University, King Fahad University for Petroleum and Minerals, King Saud University and King Faisal University

\section{UAE, federal}

Research Center for Renewable Energy Mapping and Assessment (2012)

Atlas of solar and wind resources, particularly for developing countries

Based at Masdar institute, in partnership with UAE Directorate of Energy and Climate Change; Dubai Supreme Council of Energy; and Environment Agency - Abu Dhabi. Offers MSc and PhD programmes

\begin{tabular}{|c|c|c|}
\hline UAE, Abu Dhabi & & \\
\hline $\begin{array}{l}\text { Center for Prototype Climate } \\
\text { Modeling, New York University } \\
\text { Abu Dhabi Institute (2013) }\end{array}$ & $\begin{array}{l}\text { Climate theory, modelling and } \\
\text { observation. Focus on the tropics } \\
\text { and subtropics. }\end{array}$ & $\begin{array}{l}\text { Part of New York University Abu } \\
\text { Dhabi }\end{array}$ \\
\hline $\begin{array}{l}\text { Masdar Institute of Science and } \\
\text { Technology (2007) }\end{array}$ & $\begin{array}{l}\text { Alternative energy and sustainable } \\
\text { technologies: innovation and } \\
\text { entrepreneurship, energy, water } \\
\text { and environment, microsystems } \\
\text { and smart and sustainable } \\
\text { systems }\end{array}$ & $\begin{array}{l}\text { Offers } 8 \mathrm{MSc} \text { and } 1 \mathrm{PhD} \\
\text { programmes }\end{array}$ \\
\hline
\end{tabular}

i) PIK (2012); ii) PME (2011).

Capacity can be acquired at least through three measures: employing foreign expertise, collaborating with international development agencies and partners, and participating in regional and global partnerships.

Whilst the GCC's reliance on foreign labour and expertise has received a lot of attention in the literature, it may suffice to note here that using GCC states' financial wealth to attract experts for short-term assignments may be attractive in a near-term perspective, given the quick returns, in the long term, both educational reform aimed at building knowledge-based societies and strategies aimed at securing a part of this foreign expertise in the longer term are likely to be the most sustainable options for building sustained capacity in any economic sector.

In their interactions with international (development) partners in multiple ways, both intergovernmental and with the private sector, the GCC in many cases also build domestic technical expertise relating to new technologies and knowledge. Perhaps the best examples are found in the include the energy and industrial sectors, including for example Abu Dhabi's civilian nuclear energy programme, which initially depends on Korean operators but includes measures to build national expertise in this area through a specific nuclear science and engineering degrees. ${ }^{308}$ Also many of the research institutions described in Table 7 include foreign partners.

\footnotetext{
308 Jay Solomon and Margaret Coker, 'Oil-Rich Arab State Pushes Nuclear Bid with U.S. Help', The Wall Street Journal (2 April 2009).
} 

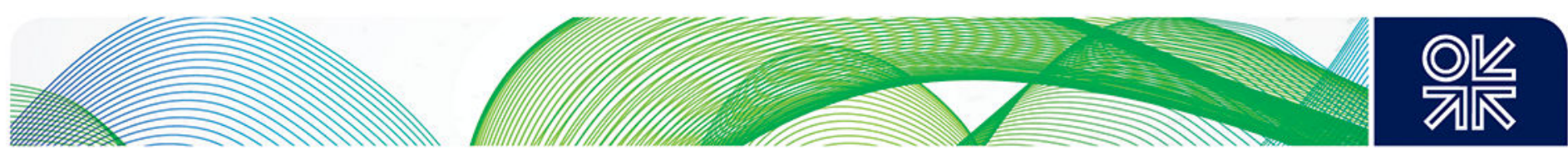

Technical and capacity-building support in the GCC is also gained through long-standing relationships with international development institutions, many of which have national or regional offices in the GCC, including UNDP, UNEP and UNESCO. Furthermore, since 2009, Abu Dhabi has hosted the headquarters of the International Renewable Energy Agency, which is working in close cooperation with the UAE Ministry of Foreign Affairs and Masdar, and since 2011, the much smaller regional office of the Global Green Growth Institute, headquartered in Seoul, South Korea. The GCC states also participate in a number of international high-level partnerships and fora that focus climate changerelevant issues. Saudi Arabia, for example, is a member of G20. Together with the UAE, it participates in the Carbon Sequestration Leadership Forum (CSLF). In addition, the UAE participates in the US-led Clean Energy Ministerials initiative and the climate policy-focused Cartagena Dialogue for Progressive Action. In general, whilst both technical and high-level cooperation on climate action with partners outside the region is intensifying, regional and intra-GCC cooperation remain weak.

Furthermore, as part of their economic and foreign policy strategies, the GCC states also seek to attract a growing number of international conferences and events, many of which bring in global experts in sustainable development and serve as starting points for further cooperation. Some major events are also acting as direct drivers of low-carbon development, such as Qatar's FIFA football world cup 2022 bid, which included a promise to deliver a carbon neutral event, the Dubai Expo 2020, which is committed to delivering a resource efficient event and generating 50 percent of the forecasted energy demand, or $44 \mathrm{MW}$ (in capacity), from solar energy. ${ }^{309}$ 


\section{Synergies with Sustainable Development in the GCC}

A systematic review of policies, actions and plans in the area of climate policy, like the one above, can help in devising better policies that take into account the synergy potential between other related policy areas and goals, including long-term development planning, economic diversification, domestic energy and resource policy, knowledge economy, and green economy.

This section examines co-benefits of a more consistent alignment of climate mitigation and adaptation policies and measures with other sustainable development policy goals, with the aim of providing pointers for the GCC states for low-emission, resource-efficient and climate-resilient development plans and pathways. In other words, this section examines mainstreaming climate policy into broader sustainable development objectives.

As evident from the analysis in Sections 3.2-4 above, the GCC states are already working on a number of projects and plans that could be converted into policies, NAMAs (under the UNFCCC economic diversification window) and other actions. These include alternative energy and energy efficiency projects and targets, a variety of sectoral mitigation policies and measures, adaptation and resilience strategies, and investments in R\&D and new industries. This paper takes a step back from proposing detailed policies or mitigation actions and examines how key elements of a low-emission development strategy (LEDS), based on the key national development priorities of the three GCC states examined (Qatar, Saudi Arabia and the UAE) could look like.

The first part of the section examines the concept of policy mainstreaming and links it to that of LEDS. The second part provides an analysis of key drivers of climate policy that can underpin sustained policies and measures to curb emissions and adapt to climate change impacts. The third part examines how these drivers are articulated in the three GCC states' long-term development plans and the more specific goals of economic diversification, energy and natural resource policy and security, and knowledge and green economy. Finally, the section provides suggestions for elements of a LEDS in the three GCC states examined.

\subsection{Mainstreaming Climate Policy with LEDS}

Mainstreaming, or bringing about 'a comprehensive integration of climate change mitigation and adaptation aims into public policies', is essential due to complex interactions between the environmental, economic and social impacts of climate policies and those of other policies. ${ }^{310}$ In this context, three aspects are crucial: policy integration, policy coherence, and multi-level governance. Mickwitz et al. define climate policy integration as 'the incorporation of the aims of climate change mitigation and adaptation into all stages of policy-making in other policy sectors'. ${ }^{311}$ Policy instruments for improving integration and coherence can be divided into three types: communicative (such as, strategies, performance reporting and reviews), organisational (such as, combinations of sectoral environmental units and independent working groups) and procedural (such as, veto or obligatory consultation rights for environmental departments, 'green budgeting' and impact assessments). Areas for mainstreaming include annual budgets, impact assessments, and spatial planning. The annual government/municipal budget is a powerful tool as it can be used to influence decisions through, for example, taxes and charges, subsidies and budget allocations (adding for positive climate impacts and removing for negative), and climate-based limits or targets for the use of budget allocations by administrative bodies. A third dimension of mainstreaming, multi-level governance is crucial given the complexity of interactions between levels and the fact that both mitigation and adaptation must be addressed at all levels and not merely as a top-down control issue, as Mickwitz at al. note. ${ }^{312}$

\footnotetext{
${ }^{310}$ Per Mickwitz et al., Climate Policy Integration, Coherence and Governance (Helsinki: Partnership for European Environmental Research, 2009), 3, 21.

Ibid., 19

312 Ibid., 11, 49, 55.
} 

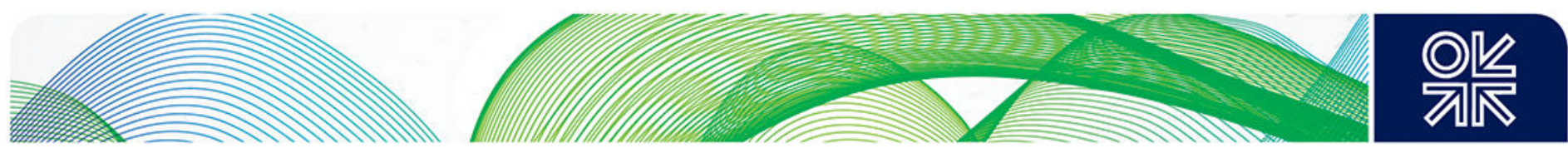

Important opportunities and synergies can be exploited and achieved through mainstreaming, including in innovation and new markets, competitiveness, general policy coordination, and stronger policy and regulatory signals. For example, Mickwitz et al. argue that environmental regulation can support innovation by pushing industries to explore opportunities that would otherwise not be considered. ${ }^{313}$ Finally, it should be noted that climate policy integration requires financial resources and human capacity. Also, climate policy integration is never free of controversy give that it requires changes in important economic sectors, such as energy and transport. ${ }^{314}$

Low-emission development strategies (LEDS) are one way of mainstreaming mitigation and adaptation into policies, through long-term planning. As noted earlier, LEDS are country-specific plans aimed at decoupling economic growth from emissions growth that are integrated in development planning, monitored and revised. Attention must be paid both to the process (including government coordination and stakeholder involvement) and to the result (formulation of a sustainable pathway with mid- and long-term national and sectoral options and actions for low-carbon development and GHG reductions and an implementation roadmap). NAMAs, in this context can serve as instruments for delivering the strategy.

\subsection{Drivers of Climate Policy and Action}

A successful climate policy or LEDS must be grounded in broader socioeconomic drivers of development and investment. Similarly to national circumstances (discussed in Section 3.1.1) the examination below is based on a division into physical, social, environmental and economic (climate) policy drivers.

Physical drivers for climate action can be divided into existing climatic and geographic conditions, and the tangible impacts of climate change. Given the hot climate and insufficient groundwater resources, sustaining electricity and desalinated water production in the GCC states is a precondition for life. With demand growth driven by population and economic growth and high per capita consumption, securing energy and water supply remains a core physical driver of development even in scenarios of lower levels of temperature rise and sustained precipitation. Food import dependence drives food security policies, which on the domestic side are starting to explore the benefits of sustainable agriculture. In addition, climate change-induced sea level rise (SLR) and extreme weather events like storms and cyclones ${ }^{315}$ can physically threaten coastal settlements and infrastructure, where the centres of economic and industrial activity of all smaller GCC states are located. Climate-resilient urban and land use planning that takes into account possibly higher sea levels in the future is therefore a necessity for the GCC states, and especially in the case of new land reclamation projects, and is also in line with the prevailing trend towards integrated land management.

Social drivers that could motivate low-emission, climate-resilient development include those related to demographic pressures, human security, health and education. High population growth in the GCC has led to growing total demand for energy and water (see Table 1), which in turn has led to natural gas shortages in a number of GCC countries (given the preference for natural gas in the electricity and water sector and insufficient availability of supplies), many of which have resorted to imports. ${ }^{316}$ Producing electricity domestically, from alternative low-emission sources, and curbing demand growth with demand management (DSM) could boost domestic energy and water security and also generate jobs for the growing populations. Burning less fossil fuels, including in transport, would decrease air pollution levels, with important positive health effects. ${ }^{317}$ Knowledge-economy building is a key development goal and economic diversification strategy in the GCC; investing in education, innovation and R\&D can therefore serve as a decarbonising strategy both through creating new economic sectors and jobs.

\footnotetext{
${ }^{313}$ Ibid., 11, 15, 29, 37.

314 Ibid., 12, 85

${ }^{315}$ E.g. Cyclone Gonu in 2007, the strongest tropical cyclone ever to hit the Arabian Peninsula.

${ }^{316}$ E.g. Luomi, The Gulf Monarchies and Climate Change, chapter 2.

317 UN News Centre, 'Outdoor Air Pollution a Leading Cause of Cancer, Say UN Health Experts' (17 October 2013).
} 
Environmental quality and sustainability are becoming increasingly important for GCC governments, following a decade of rapid and in many ways unsustainable growth. Air and water quality, waste management, efficient natural resource consumption, and biodiversity conservation are all receiving increasing attention from both governments and residents. Improving environmental quality and lessening the demands on ecosystemic carrying capacities can have important co-benefits for climate action, especially emissions abatement: lower ecological footprints (meaning less intensive consumption of natural resources and lower levels of waste generation, including GHG emissions) will also lead to lower carbon footprints. According to the Global Footprint Network, the carbon footprint represents 54 percent of humanity's total ecological footprint. ${ }^{318}$ Similar calculations in the UAE showed that $\mathrm{CO}_{2}$ accounted for 83 percent of the federation's ecological footprint. ${ }^{319}$ (Presently, the GCC states score poorly on this indicator, with Qatar, Kuwait and the UAE ranked as the countries with the highest footprints in the world in 2008 , according to the WWF ${ }^{320}$ )

Economic priorities and goals are perhaps the most powerful driver of development, both in the GCC and globally. Given the important share of the energy sector of the GCC states' GHG emissions, energy policy is another important area for synergy-searching. ${ }^{321}$ The potential drivers of low-carbon, climate-resilient development in these two areas can be divided into those related to the domestic side of the economy and those related to exports (that is, the impacts of response measures). On the domestic side, the GCC states' high and growing demand for air conditioning and desalinated water is a fiscal burden for the states, given tariffs that are insufficient for cost recovery and the cost of importing natural gas, often at international market prices. It also incurs a high opportunity cost for the export sector, in foregone revenue from oil and natural gas (and related export products), especially in Saudi Arabia and Kuwait where large quantities of oil are burned for electricity generation (see Figure 2). Furthermore, 'underpricing' of fuel and utilities continues to lock in carbon intensive infrastructure, technology and fleet choices with decades-long impacts on the economy and environment. Managing demand growth and switching to alternative (less-emitting) energy sources therefore is in line both with economic and energy policy objectives and emissions abatement.

On the response measures side, economies that are less dependent on the price cycles of oil (and natural gas), will be overall more resilient and sustainable in a low-emission world, in addition to emitting less. Economic diversification into non-hydrocarbon export sectors, or lower-emitting and downstream hydrocarbon export products would prepare the export sector for a low-emission world where the environmental externalities of GHG emissions are internalised, for example, through universal taxes, cap and trade mechanisms or, in the worst case for the GCC, trade policies. Carbon capture and storage (CCS) is seen as a win-win technology that may allow for fossil fuel exporters to decarbonise their production, including in the manufacturing sector (and thereby continue 'business as usual'), but technology costs need to come down before CCS will become an economically viable option (in the absence of a global price for carbon or sufficient market incentives, such as through the CDM). ${ }^{322}$ Finally, as the World Economic Forum's latest Global Competitiveness Report notes, environmentally sustainable practices, including natural resource use efficiency and environmental health, have been found to positively correlate with economic competitiveness. ${ }^{323}$ The drivers of synergetic climate action, based on the above analysis, are summarized in Table 8 , which also includes a selection of related policy instruments and measures.

\footnotetext{
${ }^{318}$ Global Footprint Network, 'Carbon Footprint'

[http://www.footprintnetwork.org/pt/index.php/GFN/page/carbon_footprint/], accessed in October 2013.

${ }^{19}$ Emirates Wildlife Society-WWF et al., UAE Ecological Footprint Initiative, 5.

${ }^{320}$ WWF, Living Planet Report 2012: Biodiversity, Biocapacity and Better Choices (Gland: WWF, 2012), 43.

Oman ranked $14^{\text {th }}$ and Saudi Arabia $42^{\text {nd }}$. Bahrain was not included, given that its population at the time was

estimated at less than 1 million.

${ }^{21}$ Good examples include South Korea's green growth model and the alignment of the EU's energy and climate policies.

E.g. John Gale in: Vesela Todorova, 'Experts Discuss Carbon Capture in Abu Dhabi' The National (8 November 2013).

${ }^{23}$ Klaus Schwab (ed.), The Global Competitiveness Report 2013-14. Full Data Edition, Insight Report (Geneva: World Economic Forum, 2013), 57.
} 
Table 8: Drivers of climate action grounded in broader socioeconomic priorities in the GCC.

\begin{tabular}{ll}
\hline $\begin{array}{l}\text { Policy aim with climate } \\
\text { action synergies }\end{array}$ & Possible policy tools \\
\hline Physical/security-related & \\
\hline Energy and water security of supply & $\begin{array}{l}\text { Energy demand side management (DSM); energy efficiency by a } \\
\text { variety of measures; domestic deployment of alternative energies } \\
\text { through a variety of measures, including enabling environments and } \\
\text { fiscal incentives; integrated water supply/demand management; } \\
\text { deployment of sustainable desalination technologies; expanded water } \\
\text { and fuel storage capacity }\end{array}$ \\
\hline Food security & $\begin{array}{l}\text { Sustainable domestic agriculture; sustainable trade and investment } \\
\text { policies; expanded storage capacity for strategic crops }\end{array}$ \\
\hline Sustainable and resilient land use & $\begin{array}{l}\text { Integrated land and coastal management systems; institutionalised } \\
\text { risk reduction systems; improved information and impact assessment } \\
\text { capacity }\end{array}$ \\
\hline Social &
\end{tabular}

\begin{tabular}{ll}
\hline Social & Support to new, green economic sectors, including alternative energy, \\
Employment & $\begin{array}{l}\text { Emission reductions overall by a variety of measures; emission and } \\
\text { efficiency standards for industry and transport; sustainable transport } \\
\text { infrastructure and urban planning }\end{array}$ \\
\hline Human health & $\begin{array}{l}\text { Support to knowledge and green economy (universities, R\&D and } \\
\text { innovation overall) through enabling environments and funding }\end{array}$ \\
\hline Education & Pollution control and DSM through technologies, standards, \\
regulation, incentives; education and awareness-raising
\end{tabular}




\title{
4.3 National Development Visions and Strategies
}

In order to devise functional low-emission strategies, grounded in national circumstances, it is important to keep in mind that there is some variation in the GCC states' socio-economic and emission profiles, as well as development trajectories past, present and future. These factors also affect the extent to which climate change is included in high-level economic development planning.

Current GCC decision-makers' key economic development objectives and strategic goals are most clearly expressed in national long-term development visions. Hvidt who has studied the six states' planning strategy documents in depth finds important variation: firstly, he distinguishes between two kinds of approaches to planning: whilst, of the three states examined in focus in this study, Qatar and the UAE adhere to a new, more flexible style of planning that seen as an 'interactive process of strategic cooperation between the private and the public sectors', Saudi Arabia, with a longer economic planning history, applies an older style that tries to factor in all economic and social factors. ${ }^{324}$ Other areas of divergence include key aims and leading sectors (see Table 9) and the means to achieve these aims, which range from investment in education (Qatar), through privatesector participation (Saudi Arabia), to economic reform, innovation and research, and supporting highvalue added economic sectors (the UAE). In all three, the state is seen as the key driver of economic development, and all envisage a gradual shift from allocation states towards production states. ${ }^{325}$

Table 9: National development visions and strategies of three GCC states. ${ }^{326}$

\begin{tabular}{|c|c|c|}
\hline $\begin{array}{l}\text { Vision/strategy } \\
\text { (launch year) }\end{array}$ & Key aims and leading sectors & $\begin{array}{l}\text { Explicit low-carbon and climate } \\
\text { resilience goals }\end{array}$ \\
\hline \multicolumn{3}{|l|}{ Qatar } \\
\hline $\begin{array}{l}\text { Qatar National Vision } \\
2030(2008)\end{array}$ & $\begin{array}{l}\text { Aims: Sound economic management; } \\
\text { responsible exploitation of oil and gas; } \\
\text { suitable economic diversification; } \\
\text { knowledge-based society } \\
\text { Sectors: Oil and gas; education }\end{array}$ & $\begin{array}{l}\text { Proactive and significant regional role in } \\
\text { assessing the impact of climate change } \\
\text { and mitigating its negative impacts, } \\
\text { especially in the Gulf; support for } \\
\text { international efforts to mitigate climate } \\
\text { change. }\end{array}$ \\
\hline
\end{tabular}

\section{Saudi Arabia}

Saudi Arabia's Long-term

Strategy 2004-2024

(2004)

\author{
Aims: Creating productive employment \\ for Saudi national manpower; improving \\ quality of life; doubling per capita \\ income from 2004, diversifying the \\ economy; expanding society's \\ economic base
}

Sectors: Oil and gas

\footnotetext{
${ }^{324}$ Martin Hvidt, 'Planning for Development in the GCC States: A Content Analysis of Current Development Plans', Journal of Arabian Studies 2:2 (2012), 191-2. Citation from Dani Rodrik (2004).

${ }^{325}$ Ibid., 193-4, 198.

${ }^{326}$ Vision/strategy documents; Hvidt, 'Planning for Development', 193-4; Luomi, The Gulf Monarchies and Climate Change, 97, 103-4. Nb. The UAE's second key emirate, Dubai has not produced a long-term vision. The Dubai Strategic Plan 2015 includes the aims of: economic growth and enhanced labour productivity and sector development, in the following sectors: travel and tourism; financial, professional, and transport and logistic services; trade and storage; and construction. It has one explicit climate policy-related goal: developing an integrated energy, electricity and water policy framework, including the possibility of DSM. Dubai Strategic Plan 2020 was mandated in 2013.
} 


\begin{tabular}{|c|c|c|}
\hline \multicolumn{3}{|l|}{ UAE (federal) } \\
\hline UAE Vision 2021 (2010) & $\begin{array}{l}\text { Aims: Becoming one of the best places } \\
\text { in the world for business; diversifying } \\
\text { the economy by expanding into new } \\
\text { strategic sectors } \\
\text { Sectors: Financial services; aviation; } \\
\text { trade and commerce }\end{array}$ & $\begin{array}{l}\text { Balanced growth fuelled by a sustainable } \\
\text { range of energy resources, with an } \\
\text { important role for alternative and } \\
\text { renewable energy sources; new, energy- } \\
\text { efficient technologies for a pioneering role } \\
\text { in 'the green revolution'; reduction of } \\
\text { carbon and ecological footprints; mitigation } \\
\text { of the effects of climate change through } \\
\text { GHG emission reductions and regulation } \\
\text { for ecosystem protection. }\end{array}$ \\
\hline \multicolumn{3}{|l|}{ Abu Dhabi } \\
\hline $\begin{array}{l}\text { Abu Dhabi Urban } \\
\text { Planning Vision } 2030 \\
(2007)\end{array}$ & $\begin{array}{l}\text { Aims: Coordinated urban planning: } \\
\text { coordinated growth, grounded on the } \\
\text { three pillars of sustainability; } \\
\text { sustainable resource use } \\
\text { Sectors: Construction and land use; } \\
\text { transport }\end{array}$ & $\begin{array}{l}\text { Resource efficiency; reducing energy and } \\
\text { water consumption; environmentally } \\
\text { sustainable communities and eco-villages; } \\
\text { aiming at a 'cool island effect'; sustainable, } \\
\text { low-energy design promoted by Masdar, } \\
\text { among others }\end{array}$ \\
\hline $\begin{array}{l}\text { Abu Dhabi Economic } \\
\text { Vision } 2030 \text { (2008) }\end{array}$ & $\begin{array}{l}\text { Aims: More diversified and sustainable } \\
\text { economy; reducing oil dependence; } \\
\text { employment and better education for } \\
\text { nationals, among others } \\
\text { Sectors: Oil and gas, heavy industries; } \\
\text { tourism; aviation and aerospace; health } \\
\text { care; education; media; financial } \\
\text { services; telecommunications, among } \\
\text { others }\end{array}$ & $\begin{array}{l}\text { Diversifying energy sources to reduce } \\
\text { dependence on natural gas; CCS; } \\
\text { liberalisation } \\
\text { and deregulation of elements of the } \\
\text { utilities sector (power generation) to } \\
\text { demand-sensitive provision and attract } \\
\text { private capital and international expertise. }\end{array}$ \\
\hline
\end{tabular}

i) Source for Qatar, Saudi Arabia and the UAE: Hvidt (2012).

Notably, all visionary plans examined are either based on or include mention of the notion of sustainable development. Following a general trend in developing countries, ${ }^{327}$ the need to integrate climate change in development planning is recognised in the GCC too. Different aspects of climate action are being slowly incorporated into development planning also in the GCC, albeit with different levels of extent, as illustrated by Table 9: the emirate of Abu Dhabi and the UAE are ahead of the two other states in this sense, although Qatar's vision includes two very specific regional and international level goals. However, the lack of references to low-emission or climate-resilient development in the Saudi vision can at least to some extent be attributed to its earlier date of publication, in 2004, when the issue was yet to enter the mainstream of the global development agenda.

The vision documents do not necessarily prescribe exactly how their goals are to be reached, but rather this task is delegated to either shorter-term development strategies, as in the case of for example Qatar, which launched in 2011 its first national development strategy, or supporting initiatives, as in the case of Abu Dhabi, which launched a sustainability framework, including a mandatory green building rating system, for its urban plan starting from $2008 .{ }^{328}$ Given their shorter time span, these implementation strategies can be compared to NAMAs: they have clear key shortterm goals, often accompanied by quantified targets, and sector-based, specific prescriptions on the planned actions and related follow-up, including a division of labour amongst the responsible government agencies.

\footnotetext{
${ }^{327}$ Lütken, Low Carbon Development Strategies, 6.

${ }^{328}$ General Secretariat for Development Planning (Qatar), Qatar National Development Strategy; Abu Dhabi Council for Economic Development and Abu Dhabi Urban Planning Council, Abu Dhabi Economic Vision 2030, Abu Dhabi Urban Planning Vision 2030 (Abu Dhabi: ADCED and UPC, undated), 167-98.
} 

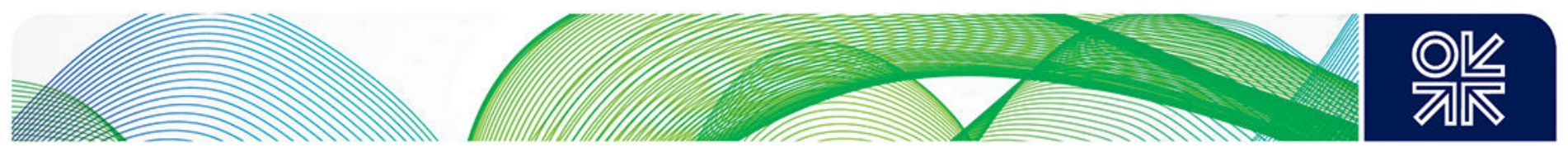

Three more specific goals of economic development are reflected in the three states' development plans, which deserve a closer look given their high synergetic potential in relation to climate action: economic diversification; energy and natural resource security and policy; and the concepts of knowledge-based and green economies. These reflect three areas of sustainable development, respectively, namely: economic sustainability, natural sustainability, and social sustainability.

\subsubsection{Economic Diversification}

Relating to economic sustainability, economic diversification has been a long-term policy goal of the GCC states since the 1970s' oil crisis, hindered by the deeply rooted allocation state structures but boosted again by the 2000s' record oil export revenues. In his analysis of the GCC states' long-term visions, Hvidt has perceptively noted that diversification is considered a solution to all problems and barriers to growth. It comprises moving downstream in the domestic hydrocarbon industry and supporting the growth of non-fossil fuel industries, including manufacturing and services. Depending on the size of their remaining oil and natural gas reserves, different GCC states demonstrate diverging levels of urgency: whilst Bahrain and Oman are pursuing diversification aggressively, the UAE signals 'little urgency' and Qatar 'deliberately aims for a "slow" diversification process'. ${ }^{329}$

Not coincidentally, economic diversification is also the overarching approach under which the GCC states, led by Saudi Arabia, are demonstrating willingness to participate in global climate action, as discussed above (see Section 2.1.6). Therefore, this should also be amongst the first areas for mainstreaming climate action domestically. Despite the state-led development model, the corporate sector, especially private enterprises, can be a powerful ally in a low-emission diversification drive. A survey by Hashmi and Al-Habib amongst 127 mid-level managers of Saudi business entities found strong support for government policies obliging corporations to manage their emissions. ${ }^{330}$ In Dubai, the government already relies on private sector participation for green development. ${ }^{331}$

\subsubsection{Energy and Natural Resource Security and Policy}

Questions of domestic energy, water and food security only emerged prominently on the GCC states' policy agendas in the late 2000 s, prompted by several years of unprecedented economic, population and energy demand growth, low domestic utility pricing, and global shocks in the price of food. As a result of these new internal pressures, and relating to what the author has described elsewhere as 'natural sustainability' or 'the use of natural resources in a way that ensures prosperity for humans and the environment, presently and in the future', ${ }^{332}$ the region's states are increasingly focusing on the demand side of the energy and resource security equation. Environmental sustainability of natural resource use has risen on the GCC agenda in parallel, prompted by concerns over international image, human health, and increasing awareness and information, among others.

Both the economic and environmental imperatives for increased natural sustainability are hence becoming increasingly obvious in the GCC. Fortunately, addressing the unsustainable patterns of domestic natural resource consumption (including energy) from an economic perspective will simultaneously lead to climate and other sustainable development benefits, as demonstrated in Table 8 above. This has also been aptly shown by Lahn and Stevens who in a recent study examine Saudi Arabia's domestic energy consumption patterns from an economic perspective, departing from the observation that, given 'historically low energy prices' and the lack of an energy consumption policy, ${ }^{333}$ the country consumes over a quarter of its oil production domestically, which could in a

\footnotetext{
${ }^{329}$ Hvidt, 'Planning for Development', 195.

${ }^{330}$ M. Anaam Hashmi and Mohammed Al-Habib, 'Sustainability and Carbon Management Practices in the Kingdom of Saudi Arabia', Journal of Environmental Planning and Management, 56 (2013), 152-3.

${ }^{31}$ Robin Mills, 'A Lot of Work Ahead for Dubai's Green Energy Plans to Take Shape', The National (27 October 2013).

Mari Luomi, Qatar's Natural Sustainability: Plans, Perceptions and Pitfalls, CIRS Occasional Paper (Doha: Center for International and Regional Studies, Georgetown University School of Foreign Service in Qatar, 2012), 1.333

On energy policy, see Sami Alnuam, 'Saudi Arabia's One More Go at a National Energy Strategy', Albawaba Business (29 September 2013).
} 
business-as-usual scenario lead to Saudi Arabia becoming a net oil importer by $2038 .{ }^{334}$ Focusing on largely economic motives for acting on consumption and pricing: maintaining oil export capacity, developing a post-oil economy, and safeguarding human health, the authors argue for a number of policy measures that are fully in line with a low-carbon transition: energy intensity targets and a related implementation programme; regulation for building and appliance standards and related enforcement; preparing the society of energy price reforms through efficiency, educational and infrastructure measures; supporting private-sector employment for nationals, including in the areas of infrastructure adaptation; and efficiency-enhancing technologies. ${ }^{335}$

An ambitious example of taking advantage of the synergies between food and water security and lowcarbon, climate-resilient development, albeit still only on paper, is Qatar's National Food Security Plan, finalised in mid-2013. ${ }^{336}$ Aiming at a holistic solution, the plan spans four areas: renewable energy deployment and research; (solar) desalination and water management for sustainable agriculture; sustainable agricultural production to increase the level of self-sufficiency; and developing a food processing industry for food security. ${ }^{337}$ The plan is expected to be implemented by the mid2020s and will receive support from Qatar's parallel infrastructure projects in preparation for the 2022 FIFA World Cup, which include a carbon neutrality pledge. Challenges remain on the way, as the multi-sector endeavour will require agreement, engagement and close coordination amongst a large number of government agencies with currently varying degrees of capacity and perceived interest in the endeavour.

\subsubsection{Knowledge Economy and Green Economy}

Relating to social sustainability, the goals of a knowledge-based economy, and more recently, a green economy, have figured visibly on GCC states' development agendas. Knowledge economy has most prominently been supported in the recent years by Qatar, whereas the UAE is, at the time of writing, drafting a medium-term national green growth development plan.

Knowledge-based economies, defined by the OECD as those 'directly based on the production, distribution and use of knowledge and information' that recognise the importance of human capital and role of knowledge and technology in economic growth. Building a knowledge economy requires investments in R\&D, education, training and 'new managerial work structures'. ${ }^{338}$ Notably, in the GCC, the aims of knowledge economy-building are closely linked to those of economic diversification, as explained by Hvidt who notes that all GCC long-term development plans emphasise human development as a diversification strategy. Given their citizens' high salary and professional expectations, the GCC states aim at diversifying into 'high-value added jobs', which in turn require high levels of education. ${ }^{339}$

In the long term, when streamlined with national sustainable development strategies, building a knowledge economy will also render important climate action benefits. As observed by the author (et al.) in a study on Qatar's Education City, Qatar's high wealth per capita has allowed it to pursue economic diversification less aggressively than the other GCC states. Since the mid-1990s, the country's leadership has invested significantly in education, starting with the more Western-minded and the elite, through a purpose-specific 'knowledge-economy vehicle', the Qatar Foundation. ${ }^{340}$ The study demonstrates how, in interaction with the development of the Qatar National Vision, based on the pillars of sustainable development, environmental sustainability has become a central and crosscutting theme of Qatar Foundation's strategy and activities, ranging from research agendas and technology development priorities focusing on environmental and clean energy technologies, through

\footnotetext{
${ }^{334}$ Lahn and Stevens, Burning Oil to Keep Cool, vii, 2.

${ }^{335}$ Ibid., vii-viii.

336 The Peninsula, 'Qatari Govt Receives National Food Security Plan from QNFSP' (27 August 2013).

${ }^{337}$ QNFSP website [http://www.qnfsp.gov.qa/], accessed in December 2013.

338 OECD, The Knowledge-Based Economy, OCDE/GD(96)102 (Paris: OECD, 1996), 7, 9.

${ }^{339}$ Hvidt, 'Planning for Development', 196.

340 Mari Luomi, John T. Crist, Bushra Alam and Muhammad Bilal Shakir, Environmental Sustainability in Education City: Green Beacon or Green Islands? UREP Final Report (Doha: Georgetown University School of

Foreign Service in Qatar, 2013), 5. Unpublished.
} 

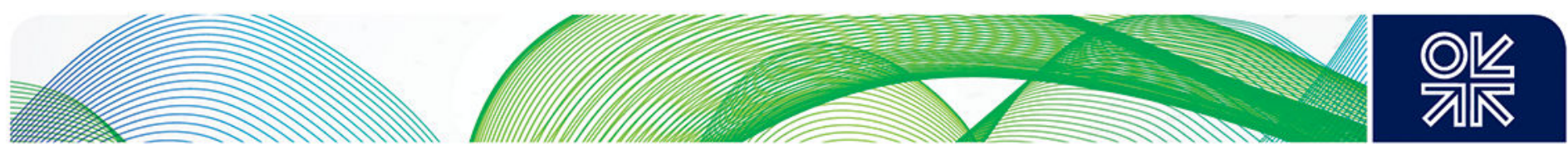

sustainable construction and infrastructure projects and polysilicon industries, to educational initiatives at the member universities. (The main challenge of Qatar Foundation, similarly to other GCC states supporting similar experiments, will be to expand its knowledge economy beyond its borders, as this will require a fundamental shift in the entire educational system, including related culture and expectations in the entirety of Qatari society.)

In many ways related, but conceptually distinct, is the idea of green economy/growth. Whilst the focus in a knowledge economy is on human capital, the focus in a green economy is more directly aimed at achieving low-carbon trajectories in the economy, more specifically maintaining economic growth whilst mitigating climate change through promoting job-creation in low-emission and environmentally sustainable sectors, in other words, 'green jobs'. A recent concept in the global development discourse, ${ }^{341}$ the most common definition is by the UNEP of green economy as 'one that results in improved human well-being and social equity, while significantly reducing environmental risks and ecological scarcities', in other words an economy that is 'low-carbon, resource efficient, and socially inclusive' and in which 'growth in income and employment are driven by public and private investments that reduce carbon emissions and pollution, enhance energy and resource efficiency, and prevent the loss of biodiversity and ecosystem services'. ${ }^{342}$

In other words, green growth is envisaged as a win-win low-carbon transition strategy for the economy, society and environment. The concept also incorporates the recognition of the need to include natural capital in calculations of present and future well-being. ${ }^{343}$ A report by the Arab Forum on Environment and Development describes the green economy agenda as consisting of decoupling economic growth and domestic energy demand and reducing per capita ecological footprints without impairing quality of life. ${ }^{344}$ Literature and policy plans working with the concept generally propose sector-based actions, including in energy, industry, cities and buildings, transport, waste, water, agriculture, and tourism. ${ }^{345}$

Of the GCC states, the UAE has embraced the green economy agenda the most enthusiastically. Both the UAE and Qatar are founding members and the only non-OECD donors to the Global Green Growth Institute (GGGI), an international institution founded in 2010 to support the integration of economic growth and environmental sustainability around the world. The GGGI opened a regional office in Abu Dhabi in 2011. In addition, the UAE has taken the agenda a step further by launching a process to develop a national green growth strategy, which it has developed through a multi-sector consultation process involving 70 private and public bodies. With implementation expected to begin in 2014, the UAE Strategy for Green Development will streamline the various existing emirate-level 'green' initiatives, including building codes, and include legislation, policies, programmes and projects in six areas: renewable energy, clean fuels and energy efficiency; investments and jobs; sustainable urbanism; emission reductions and environmental sustainability; rational use of natural resources and awareness-raising and education; and clean technologies, including CCS and waste-to-energy. ${ }^{346}$ The government also participates in the Partnership for Action on Green Economy (PAGE), which

\footnotetext{
${ }^{341}$ First coined in 1989 by Pearce et al., the concept of green economy was brought to global attention around 2009 as an economic recovery strategy focused on creating 'green jobs' and tackling climate change. South Korea was the first country to declare 'Low Carbon Green Growth' as its long-term national development vision, in 2008. The concept of has not been embraced by all countries without criticism.

42 UNEP, Towards a Green Economy: Pathways to Sustainable Development and Poverty Eradication (Nairobi, UNEP, 2011). 16.

343 Ibid., 17.

344 Ibrahim Abdel Gelil et al., 'Energy,' in Hussein Azaba et al. (eds.), Green Economy: Sustainable Transition in a Changing Arab World, 2011 Report of the AFED (Beirut: AFED, 2012), 77, 104

E.g. UNEP, Towards a Green Economy; Azaba et al., Green Economy; WAM, 'Mohamed Unveils UAE's Green Economy' (15 January 2012).

${ }^{346}$ The initiative is led by the Ministry of Environment and Water, with the Ministry of Foreign Affairs, Office of the Prime Minister and the Global Green Growth Institute. Vesela Todorova, 'Clean Fuels Top UAE's Green Strategy' (14 May 2013); Dubai Global Energy Forum, Clean Energy for Sustainable Development, brochure (2013), 9; Kannan, 'UAE Devises'.
} 

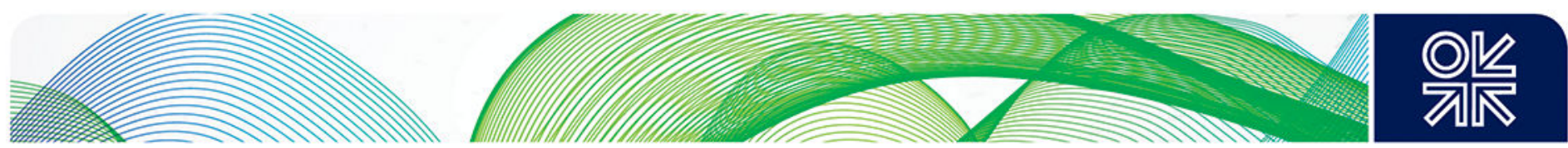

works with 30 countries to achieve a sustainable transformation of national economic structures to 'inclusive green economies', and will host the first conference of the partnership in Dubai, in $2014 .^{347}$

The green growth strategy is part of a broader shift in government thinking and the UAE's regional positioning, described by a high-level official working on climate policy as aiming to 'lead by example and create a sustainable growth model for oil-based economies'. ${ }^{448}$ Despite the obvious alignment of the UAE's plan with low-carbon, climate-resilient development, the challenge for the UAE, as for other GCC states devising ambitious sustainable development plans, will be to move from plans to consistent implementation.

\subsection{Towards Low-Emission, Climate-Resilient Development}

This section has discussed key aspects of climate policy mainstreaming and indicated areas where which climate action is in line, in relation to (i) broader socioeconomic drivers, (ii) national long-term development plans, and (iii) specific economic development goals. These provide clear elements for the basis of a LEDS in the three GCC states examined, and possibly the others as well.

The actual process for developing a LEDS includes some of the steps already taken in this study, including an assessment of the current situation and analysis of strategic options. A number of technical resources, including some from the UNDP and the OpenEI, coincide with the process description:

1. Organization of the LEDS process: development of a multi-stakeholder climate planning process;

2. Situational assessment: preparation of climate change profiles and vulnerability scenarios;

3. Analysis of options: identification of strategic options leading to low-emission, climate-resilient development;

4. Prioritization of actions: identification of policies and financing options for implementing priority climate actions; and

5. Preparation of a LE(CR)DS roadmap, implementation, and monitoring. ${ }^{349}$

As established in this study, the GCC states are well positioned to initiate a transition to a lowemission, climate-resilient future. Despite their high per-capita emission profiles and vulnerability to climate change, there is important scope for emission reductions, in all economic sectors, through a variety of policies and measures, and for increasing resilience. Whilst numerous projects, initiatives and even targets have been established towards this end, climate mainstreaming is only beginning to emerge on the decision-makers' radars, through long-term development plans and more specific economic development goals and strategies. Most importantly, however, this study has shown that there are extensive co-benefits that can be achieved by mainstreaming climate action in to sustainable development in the GCC, including for economic diversification, natural sustainability and building a green knowledge-economy.

\footnotetext{
347 The institutions supporting the partnership are: UNEP, ILO, UNIDO and UNITAR. Partnership for Action on Green Economy, brochure (2013), 4-5; Albawaba, 'Amidst the Sand, UAE is Going "Green" with First UN Green Economy Conference Scheduled for March' (13 November 2013).

${ }^{348}$ Chatham House workshop Approaching COP18.

349 UNDP, 'Green LECRDS Guidance Manuals and Toolkits'

[http://www.undp.org/content/undp/en/home/ourwork/environmentandenergy/focus_areas/climate_strategies/gree n_lecrds_guidancemanualsandtoolkits/]; OpenEI, 'Low Emission Development Strategies (LEDS) Gateway'

[http://en.openei.org/wiki/Gateway:Low_Emission_Development_Strategies], both accessed in December 2013.
} 


\section{Conclusions: Accelerating Action in the GCC}

After having established the GCC states' emission profiles and mitigation and adaptation potential, analysed their existing policies and actions in three GCC states, and mapped areas where climate policy could be mainstreamed with current development strategies, this final section draws some conclusions in three areas, namely: where actions could be accelerated and what additional actions could be taken; where the key obstacles and limits to more ambitious climate action lie; and how the GCC states can maximise the benefits of adopting clear policies to combat climate change.

\subsection{Potential for Accelerated and Further Action}

As discussed in Section 1, both economic realities and national interest perceptions of GCC states are leading to a more proactive engagement with the climate change agenda, both international and domestic. Given the politisation of the international climate regime, a bottom-up analysis that departs from each country's national circumstances, examines their emission profiles and mitigation potential, and establishes areas of synergies with broader socio-economic goals can be more productive in driving ambitious climate action at home that can later be registered at the international level, as determined appropriate by the states. Section 2 examined the framework in which international climate action and support currently evolves, including the policy and strategic tools of NAMAs and LE(CR)DS. It also presented the wide toolkit of both economy-wide and sectoral climate policies and measures in the areas of mitigation, and adaptation and resilience to climate change and response measures.

The first past of Section 3 established the climate policy context of the GCC states by examining national circumstances, as defined by the states themselves, emission profiles, including future scenarios, capabilities and vulnerabilities, and relevant institutional arrangements. The analysis showed that, despite strong economic capacity to adapt to the current climatic conditions, the GCC states are well aware of their physical and economic vulnerability to climate change and related response measures. Economic diversification and human development are the governments' development priorities but addressing environmental problems resulting from the past decade's rapid growth, whist increasingly recognised, is still relatively low on the agenda and will require stronger policy frameworks, institutional mechanisms and multi-stakeholder engagement than presently. An examination at GHG emission profiles of the six states showed that, in terms of total emissions, the GCC states are low historic emitters but fall in different categories with regard to present and future emissions, with Saudi Arabia ranking amongst the world's top-20 emitters. It also revealed that, despite the large manufacturing and construction sectors, electricity is the major component of most GCC states' energy-related emissions.

Despite uncertainty of data regarding fugitive emissions, the analysis indicates room for significant cuts in most states. Another important area where energy security, economic gains and mitigation encounter is shifting from oil use in the electricity sector to cleaner fuels, in particular in Kuwait and Saudi Arabia. The GCC states' mostly high (and in some cases increasing) carbon intensity indicates important space for improvement across the economy, both in terms of efficiency and decreasing the carbon content of the energy supply, which is confirmed by the emissions modelling studies examined. As noted earlier, two types of conclusions can be drawn from these studies: firstly, emission reduction potential compared to baseline projections is significant, and in some cases, perhaps most prominently the emirate of Abu Dhabi, governments are already planning for deviations. Following through with the plans remains a challenge. Secondly, the national circumstances of the GCC states determine the efficacy of different measures to cut emissions: efficiency improvements and demand side measures can play an important role and are economically attractive. Utility pricing reforms can result in major reductions but must be accompanied with education and awarenessraising. Finally, the study found that given the similarity of GHG emission profiles in terms of sectoral distribution and their national circumstances, the potential areas and measures for enhanced action are similar for all six states. 

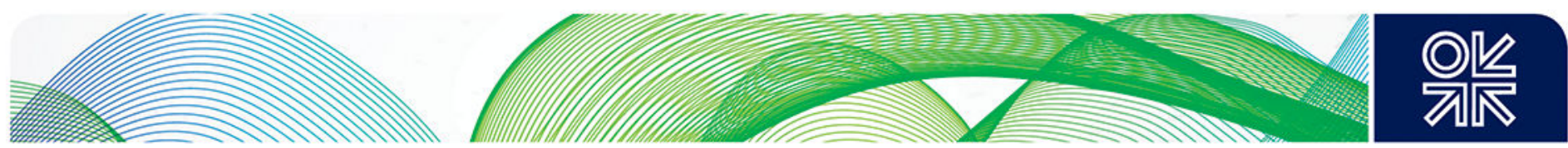

The second part of Section 3 zoomed in on three of the most active GCC states in terms of climate plans and action: Qatar, Saudi Arabia and the UAE. Whilst economy-wide measures are nearly nonexistent, the study found a wealth of often sector-based project activities and medium-term plans that either seek to address emissions directly or have emissions reductions as co-benefits. Most actions are (appropriately) undertaken in the energy supply sector, but buildings and other sectors too are receiving attention. Whilst the portfolio of policies and measures is already broad, and expansive, there is in some cases a lack of coordination between projects undertaken by different institutions. Also, some policy tools, possibly for being perceived as politically unattractive, remain untouched, including emission and energy taxes, emissions permits, or emission targets for major point source emitters. Domestic energy pricing regimes are also heavily in favour of the existing fossil fuel-heavy, energy intensive energy pathways. However, by consistently addressing emissions through the existing measures and policies, including by implementing all plans as far as feasible, the GCC states can already achieve important deviations from BAU emission trajectories. Not unimportant is the three states' increasingly active participation in international mechanisms and cooperative and capacitybuilding initiatives, foreign investments in clean energy ventures, and investments in R\&D. However, important intra-GCC synergies are yet to be exploited in these areas.

Section 4 presented the case for mainstreaming of climate policy and developing low-emission and climate-resilient development strategies (LECRDS) by demonstrating how the goals of climate policy are aligned with the broad drivers of socioeconomic development, the three GCC states' governments' development visions and strategies, and more specific development goals, including economic diversification, natural resources security and sustainability, knowledge-economy building and the pursuit of green growth. Whilst a LECRDS need not be expressed in one single document, a similar exercise to the one in this study, with engagement of all relevant sectoral stakeholders, would undoubtedly help build confidence amongst the GCC decision-makers of the wide scope of opportunities in mainstreaming climate action across all development plans and their implementation through targets, policies, regulation, programmes and projects.

\subsection{Obstacles and Limits to Action}

Undoubtedly, as in all economic transitions, a transition to a low-carbon economy and society will have its winners and losers, not the least those in the fossil fuel industry. Consequently, low-carbon transitions should be designed and framed in a way that encourages those in the most affected industries to reinvent themselves. International oil companies transforming themselves into energy companies is perhaps the most prominent example. Perhaps even more important, however, are certain economic and social obstacles and limits to change. The difference between obstacles and limits to climate action is that whilst the former can be overcome, the latter constitute the actual points beyond which further action is not possible, at least within a fast enough timeframe.

Limits to climate action in the GCC are relatively straight-forward and relate to the countries' narrow scope for economic diversification away from hydrocarbons export-dependence in the short and medium-term. The GCC states are poor in natural resources other than oil and natural gas (except solar radiation), and transformations into Singapore-like hubs specialising in services and high-value exports and Dubai-style entrepôt trade are only possible in the longer term, with the appropriate kind of labour. Complicating matters is the fact that the time available to the GCC states to make this conversion is as of yet unknown and depends on external factors. As suggested above in relation to the issue of unburnable carbon (Section 2.1.5), time may be much more limited than regional public debates currently suggest. Limitations to the speed of transformation are also posed by the increasing pressures to sustain social and socioeconomic spending, which may occupy a lot of the governments' attention and financial resources over the next decades if not properly addressed through determined economic and political reform.

According to the UNFCCC, barriers to climate action can be technical, economic, political, cultural, social, behavioural and institutional. They vary between countries and change over time. Hence, an analysis for identifying and prioritising barriers should be country-specific and be included as an 

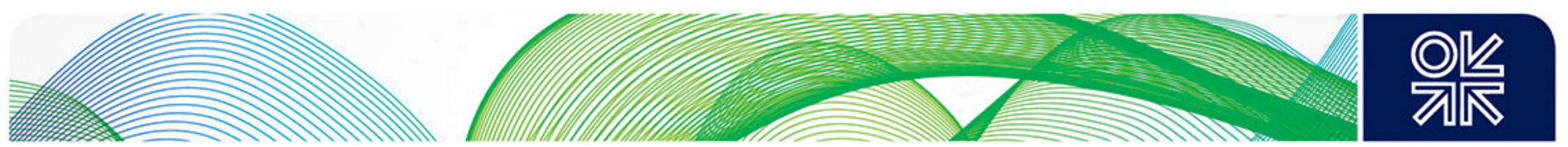

integral part in mitigation assessments. ${ }^{350}$ Some of the most important obstacles to accelerated climate action in the GCC can be divided into four areas: economic-structural, capacity-related, political, and implementation-related.

Economic-structural: A structural obstacle that also imposes important limitations to the speed of transition into a low-carbon economy is the (late) rentier state. As Hvidt has noted, the GCC states all agree that problems relating to the current rentier state model act as barriers to economic growth: depletion of fossil fuel reserves (in Bahrain and Oman); oil price fluctuations; dependence on imported labour and insufficiency of 'right kind' of jobs for nationals; increasing challenges in maintaining the national populations' living standards; and national labour force-related 'motivational and capability' issues. ${ }^{351}$ Diversification is seen as a solution to all these problems, as pointed out earlier. Importantly, related strategies should be employed in a way that simultaneously encourages resource-efficiency and transitions the economy and society into a lower-carbon and more resilient trajectory. At present, capacity support for developing LE(CR)DS or green economy strategies that integrate both goals is readily available through international development agencies. Importantly, securing sufficient financial resources for implementing planned climate actions, including through budget allocations, public-private partnerships and support to low-carbon and resilience-oriented economic sectors, is crucial.

Capacity-related: A report on the Arab region by the League of Arab States and UN-ESCWA from 2005 pin-points two key institutional challenges that still to apply to the GCC: lack of ability of institutional frameworks to effectively manage the sustainable development process owing to a sector-based approach to environmental management; and lack of multi-layer institutional arrangements that bring in the private sector and not-for-profit organisations, including the academia and NGOs. ${ }^{352}$ A recent workshop on climate change in the Arab region established a number of other challenges relating to institutions and capacity: difficulty of integrating climate change into national development plans without a strong 'champion institution'; lack of clarity on institutional responsibilities regarding climate action; failure to bring on board all sectors and stakeholder groups; absence of links between science and activities on the ground; lack of awareness at the policy-maker level; and low status of climate change and environmental issues on the national agendas leading to lack of implementation. ${ }^{353}$ As mentioned above, the GCC states are already acquiring capacity through a variety of channels, but building sustained human capacity for the long term should be the overarching goal, as this will also build institutional capacity and resilience.

Political: Domestic pricing regimes of fuels, electricity and water, at below cost-recovery rates constitute an important obstacle to further deployment of renewable energy and offer few incentives for energy conservation and efficiency. The motives behind maintaining the current regimes are both economic (relating to a comparative advantage for energy-intensive industries) and political (relating to a fear of a public backlash from higher tariffs). However, the divergence in the extent of natural resource endowments and their exploitation amongst the GCC translates to differences in the extent to which energy pricing reforms may appeal to the decision-makers. In relation to natural gas, the currently preferred source for domestic electricity production, there is important variation: at one extreme is the emirate of Dubai which currently imports natural gas from in and outside the Gulf. At the other extreme is Qatar, the world's top LNG exporter that has relatively abundant natural gas for domestic use, including industries. Regarding oil, the domestic use of which carries and important opportunity cost, Kuwait and Saudi Arabia currently use significant quantities of oil for domestic electricity production (see Figure 2). It is in these two countries latter where renewable energy, in particular PV solar, would make economically most sense. ${ }^{354}$ However, given the different sociopolitical in which the GCC energy policies are embedded, future trajectories do not look quite so straightforward: Krane who examined the potential for price subsidy reforms through over 90 expert

\footnotetext{
UNFCCC, Module 4: Measures to Mitigate, 20-1.

Hvidt, 'Planning for Development', 195.

League of Arab States Technical Secretariat of the Council of Arab Ministers Responsible for the

Environment, Arab Region State of Implementation on Climate Change (2005), 9-10.

Arab Climate Resilience Initiative, Climate Change Negotiations and Climate Finance: Opportunities and

Challenges for the Arab States: Summary Report (Bonn: 16-17 June 2013), 5-6.

Krane, 'Hype and Reality', 89.
} 

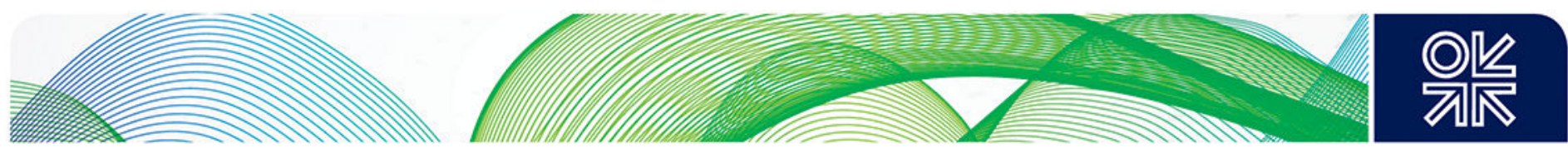

and stakeholder interviews found that Saudi Arabia and the UAE are the likeliest to reform prices, whilst Qatar and Kuwait are the least likely to do so. ${ }^{355}$ Supporting the case for domestic price increases, Luciani points out that experience so far in the UAE and Iran shows that, should the GCC governments decide to increase prices, a negative political backlash 'is not a necessary outcome, and much depends on the specific modalities of introducing price increases'. ${ }^{356}$ Importantly, environmental education, awareness-raising and communication should be aligned with necessary, and in most cases inevitable, near-term utility and fuel pricing reforms.

Implementation-related: In a coalescence of the above-described barriers, even if ambitious climate strategies are drafted, sustained implementation to achieve the set goals can be considered as the key challenge for the GCC states in the case of low-carbon development. Whilst leadership determination and attention to specific policy areas and goals undoubtedly plays a crucial role in the Gulf in determining the success of any major state endeavour, previous lessons from the alternative energy sector indicate that technology choices, in particular when environmental costs are not internalised, can sometimes be guided by immediate-term gains at the expense of long-term benefits. Abu Dhabi's nuclear and renewable energy plans, launched in 2008 and 2009, respectively, are a case in point. The broader problem facing prompt climate action world-wide is indeed that governments, including in the GCC, tend to work financial cycles too short to sufficiently factor in the costs of delayed climate action. As demonstrated by this study, however, the GCC states have both the potential and the motives for taking prompt action, for the sake of their future generations.

\subsection{Maximising the Benefits of Established Climate Policies}

At the domestic level, this study has clearly demonstrated the large potential for enhanced mitigation and adaptation action in the GCC states, and how mainstreaming climate policy and integrating its aims into those of long-term economic planning and other more specific development strategies, including economic diversification, sustainable use of natural resources, and green and knowledge economy-building, can bring benefits that will help the states achieve sustainable economies and human and environmental prosperity whilst curbing emissions and increasing climate resilience.

Given the structural and even cultural similarity of the GCC states, important synergies could be achieved from regional cooperation, including through: information-sharing; technical research and technology development; common standards; and joint pilot and other projects. ${ }^{357} \mathrm{~A}$ few examples of possible areas for streamlining, harmonisation and collaboration are the knowledge-economy initiatives (Education City, Masdar City, and KAUST), green building codes (GSAS, Estidama and LEED), and energy savings and rationalisation through the GCC Interconnection Grid. ${ }^{358}$ Publicprivate partnerships are a further area where there is both interest and potential for developing new technologies and solutions adapted to local climatic and social conditions. ${ }^{359}$ Despite the GCC states' poor track record in cooperation in R\&D, policy and a number of other areas, it is clear from numerous policy and other declarations that the countries of the bloc both demonstrate a keen interest in working together in the energy sector and, more specifically in moving together in the UNFCCC context. In this respect, the economic diversification initiative provides an important frame for registering actions at the international level, both for recognition and support.

\footnotetext{
355 Ibid., 87

356 Luciani, Energy Efficiency Policies in the MENA, 13.

357 Chatham House workshop Approaching COP18.

${ }^{358}$ See e.g. Laura El-Katiri, Interlinking the Arab Gulf: Opportunities and Challenges of GCC Electricity Market Cooperation (London: Oxford Institute for Energy Studies, 2011).

${ }^{5}$ On interest, see e.g. Minister Ali Al-Naimi's speech in the COP19/CMP9 joint high-level segment, Warsaw, 20 November 2013. On potential, see e.g. Luciani, Energy Efficiency Policies in the MENA, 15.
} 


\section{Bibliography}

\section{PUBLICATIONS}

ABB, Saudi Arabia Energy Efficiency Report (April 2012).

Abdel Gelil, Ibrahim, Farid Chaaban, and Leila Dagher, 'Energy,' in Hussein Azaba, Najib Saab, and Bashar Zeitoon (eds.), Green Economy: Sustainable Transition in a Changing Arab World, 2011 Report of the Arab Forum for Environment and Development (AFED) (Beirut: AFED, 2012), 75112.

Abou Hadid, Ayman F., 'Food Production', in Mostafa K. Tolba and Najib W. Saab (eds.), Arab Environment: Climate Change. Impact of Climate Change on Arab Countries. 2009 Report of AFED (Beirut: AFED, 2009), 63-74.

Abu Dhabi Council for Economic Development and Abu Dhabi Urban Planning Council, Abu Dhabi Economic Vision 2030, Abu Dhabi Urban Planning Vision 2030 (Abu Dhabi: ADCED and UPC, undated).

Arab Climate Resilience Initiative, Climate Change Negotiations and Climate Finance: Opportunities and Challenges for the Arab States: Summary Report (Bonn: 16-17 June 2013).

Assaf, Hamed, 'Infrastructure', in Mostafa K. Tolba and Najib W. Saab (eds.), Arab Environment: Climate Change. Impact of Climate Change on Arab Countries. 2009 Report of the AFED (Beirut: AFED, 2009), 113-20.

Broderick, J., and K. Anderson, Has US Shale Gas Reduced $\mathrm{CO}_{2}$ Emissions? Technical Report (Manchester: Tyndall Centre for Climate Change Research, 2012).

Brown, Oli, and Alec Crawford, Rising Tensions: Climate Change and the Risk of Violent Conflict in the Middle East (Winnipeg: International Institute for Sustainable Development, 2009).

Chi-Nguyen Cam, Wynn, Technologies for Climate Change Mitigation: Building Sector, TNA Guidebook Series (UNEP Risoe Centre, 2012).

Chinery, Leslie E., Modeling Trasportation in Abu Dhabi: A 25-Year Projection of Emissions under Alternative Scenarios of the Passenger Fleet, Master's thesis (Chapel Hill: University of North Carolina, 2010).

CNA Corporation, National Security and the Threat of Climate Change (Washington D.C.: CNA Corporation, 2007).

Council of Arab Ministers Responsible for the Environment, Statement on Climate Change (2009), Arabic.

Creed, Adrian, and Amir Kordvani, 'Recent Developments in the Renewable Energy Sector in MENA and Central Asia' (Clyde \& Co., 23 September 2013).

Dargin, Justin, The Development of a Gulf Carbon Platform: Mapping Out the Gulf Cooperation Council Carbon Exchange, Working Paper No 1. (Cambridge, MA: The Dubai Initiative, 2011).

DeFelice, Nicholas B., and Jacqueline MacDonald Gibson, 'Effect of Domestic Water Use on Air Pollutant Emissions in Abu Dhabi, United Arab Emirates', International Journal of Energy and Environmental Engineering, Vol. 4, 33 (2013), 1-10.

Depledge, Joanna, 'Striving for No: Saudi Arabia in the Climate Change Regime', Global Environmental Politics, 8 (2008), 9-35.

Dubai Global Energy Forum, Clean Energy for Sustainable Development, brochure (2013).

Ecofys, Mapping Carbon Pricing Initiatives: Developments and Prospects 2013 (Washington D.C.: Carbon Finance at the World Bank, 2013).

El-Din El-Quosy, Dia, 'Fresh Water', in Mostafa K. Tolba and Najib W. Saab (eds.), Arab Environment: Climate Change. Impact of Climate Change on Arab Countries. 2009 Report of the AFED (Beirut: AFED, 2009), 75-86. 
El-Katiri, Laura, Interlinking the Arab Gulf: Opportunities and Challenges of GCC Electricity Market Cooperation (London: Oxford Institute for Energy Studies, 2011).

El-Raey, Mohamed, 'Coastal Areas', in Mostafa K. Tolba and Najib W. Saab (eds.), Arab Environment: Climate Change. Impact of Climate Change on Arab Countries. 2009 Report of the AFED (Beirut: AFED, 2009), 47-62.

Elzen, den, M., and N. Höhne, 'Reductions of Greenhouse Gas Emissions in Annex I and non-Annex I Countries for Meeting Concentration Stabilisation Targets', Climate Change, 91 (2008), 249-74.

Emirates Wildlife Society-WWF, UAE Ministry of Environment and Water, Environment Agency - Abu Dhabi and Global Footprint Network, UAE Ecological Footprint Initiative, supplement for the Living Planet Report 2010 (UAE, 2010).

Environment Agency - Abu Dhabi (EAD), Climate Change Impacts, Vulnerability and Adaptation (Abu Dhabi: EAD, 2009).

EAD and Emirates Wildlife Society-WWF, Heroes of the UAE - Water Fact Sheet (undated/2009).

European Council, Conclusions on Preparations for the 19th session of the Conference of the Parties (COP 19) to the United Nations Framework Convention on Climate Change and the $9^{\text {th }}$ Session of the Meeting of the Parties to the Kyoto Protocol (Warsaw, 11-22 November 2013) (Luxembourg, 14 October 2013).

Faber, Jasper, et al., Behavioural Climate Change Mitigation Options and Their Appropriate Inclusion in Quantitative Longer Term Policy Scenarios, Delft Report (Delft: CE Delft, 2012).

Fattouh, Bassam, and Laura El-Katiri, Energy Subsidies in the Arab World, Arab Human Development Report Research Paper Series (UNDP Regional Bureau for Arab States, 2012).

Fenhann, Joergen, CDM Pipeline, 1 October 2013 (UNEP Risoe Centre, 2013).

General Secretariat for Development Planning (Qatar), Qatar National Development Strategy 2011 2016 (Doha: GSDP, 2011).

_- Qatar National Vision 2030 (Doha: GSDP, 2008).

Global Gas Flaring Reduction, Global Gas Flaring Reduction Partnership (GGFR): Improving Energy Efficiency \& Mitigating Impact on Climate Change (World Bank, 2011).

Global Methane Initiative, Oil and Gas System Methane: Reducing Emissions, Advanced Recovery and Use, brochure (September 2011).

Hashmi, M. Anaam, and Mohammed Al-Habib, 'Sustainability and Carbon Management Practices in the Kingdom of Saudi Arabia', Journal of Environmental Planning and Management, 56 (2013), 140-57.

Hiwar, 'Hiwar Session: UAE Vision 2021 and the Green Growth Strategy,' Summary Report (Abu Dhabi Sustainability Group, May 2013).

Holm Olsen, Karen, 'NAMAs for Sustainable Development', TERI Newsletter on NAMAs, Vol. 3 (4) and 4 (1), October-January 2013, 13-8.

Hvidt, Martin, 'Planning for Development in the GCC States: A Content Analysis of Current Development Plans', Journal of Arabian Studies 2:2 (2012), 198-207.

Höhne, Niklas, and Caroline de Vit, What to Expect from Climate Negotiations in Warsaw?, Ecofys Policy Update, Issue V, (October 2013).

International Energy Agency (IEA), $\mathrm{CO}_{2}$ Emissions from Fuel Combustion, 2013 edition (Paris: OECD/IEA, 2013).

, Energy Balances of Non-OECD Countries, 2012 edition (Paris: OECD/IEA, 2012).

-, Redrawing the Energy-Climate Map. World Energy Outlook Special Report (Paris: OECD/IEA, 2013).

- World Energy Outlook 2012 (Paris: OECD/IEA, 2012).

Institute for Sustainable Development Reporting Services (IISD-RS), COP18 side event on 'Carbon Management in GCC Countries', report (6 December 2012).

_ COP 18 side event on 'Global Update on Carbon Capture and Storage (CCS) and Regional Project Perspectives', report (1 December 2012).

- 'Summary of the 12 Session of the Working Group I of the IPCC and $36^{\text {th }}$ Session of the IPCC: 23-26 September 2013', Earth Negotiations Bulletin, Vol. 12, No. 581.

, Earth Negotiations Bulletin, Vol. 12, No. 546. 
Krane, Jim, 'Renewable Energy: Hype and Reality', Aspenia International, No. 59-60 (2013), 84-9.

Lahn, Glada, and Paul Stevens, Burning Oil to Keep Cool: The Hidden Energy Crisis in Saudi Arabia

(London: Chatham House, 2011).

League of Arab States Technical Secretariat of the Council of Arab Ministers Responsible for the

Environment, Arab Region State of Implementation on Climate Change (2005).

Luciani, Giacomo, Energy Efficiency Policies in the MENA Countries (2012), 9-10. Available at:

[http://www.princeton.edu/ gluciani/publications.html], accessed in November 2013.

Luomi, Mari, Bargaining in the Saudi Bazaar: Common Ground for a Post-2012 Climate Agreement?,

FIIA Briefing Paper 48 (Helsinki: The Finnish Institute of International Affairs, 2009).

_- Greening for Self-Conservation? Energy Security and Responses to Climate Change in the

Small Gulf Monarchies, PhD thesis, (Durham: University of Durham, 2011), 87-90.

_- Qatar's Natural Sustainability: Plans, Perceptions and Pitfalls, CIRS Occasional Paper (Doha:

Center for International and Regional Studies, Georgetown University School of Foreign Service

in Qatar, 2012).

- The Gulf Monarchies and Climate Change: Abu Dhabi and Qatar in an Era of Natural

Unsustainability (London: Hurst, 2012).

Luomi, Mari, John T. Crist, Bushra Alam and Muhammad Bilal Shakir, Environmental Sustainability in

Education City: Green Beacon or Green Islands? UREP Final Report (Doha: Georgetown

University School of Foreign Service in Qatar, 2013), 5. Unpublished.

Lütken, Søren, Jørgen Fenhann, Miriam Hinostroza, Sudhir Sharma and Karen Holm Olsen, Low

Carbon Development Strategies: A Primer on Framing Nationally Appropriate Mitigation Actions (NAMAs) in Developing Countries (UNEP Risoe Centre, 2011).

Mattoo, Aaditya, and Arvind Subramanian, Equity in Climate Change: An Analytical Review, Policy Research Paper 5283 (Washington D.C., The World Bank, 2010).

McGlade, Christophe, and Paul Ekins, 'Un-burnable Oil: An Examination of Oil Resource Utilisation in a Decarbonised Energy System', Energy Policy, 64 (2014), 102-12.

Meinshausen, Malte, Nicolai Meinshausen, William Hare, Sarah C. B. Raper, Katja Frieler, Reto Knutti, David J. Frame and Myles R. Allen, 'Greenhouse-gas Emission Targets for Limiting Global Warming to $2 \square^{\circ} \mathrm{C}$ ', Nature, 458 (2009), 1158-62.

Met Office/Hadley Centre, Climate: Observations, Projections and Impacts: Saudi Arabia (Exeter: Met Office, 2011).

Mickwitz, Per, et al., Climate Policy Integration, Coherence and Governance (Helsinki: Partnership for European Environmental Research, 2009).

OECD, The Knowledge-Based Economy, OCDE/GD(96)102 (Paris: OECD, 1996).

O'Sullivan, Edmund, 'Gas Flaring Efficiencies Save Kuwait Oil Company \$2.75bn', MEED (2 June 2013).

Oxford Business Group, The Report: Dubai 2013 (Dubai, OBG, 2013).

Partnership for Action on Green Economy, brochure (2013).

Picard, David, 'Fugitive Emissions from Oil and Natural Gas Activities', background paper for Good Practice Guidance and Uncertainty Management in National Greenhouse Gas Inventories (IPCC, 2000).

Radhi, Hassan, and Steve Sharples, 'Forecasting Carbon Emissions of the UAE Residential SectorA Case Study of Abu Dhabi', in Magali Bodart and Arnaud Evrard (eds), $27^{\text {th }}$ Conference on Passive and Low Energy Architecture, Belgium, July 2011, Proceedings, Vol. 1., 251-6.

Regional Center for Renewable Energy and Energy Efficiency, Arab Future Energy Index, AFEX 2013: Renewable Energy (Cairo, RCREEE, 2013).

Regulation and Supervision Bureau (Abu Dhabi), Report: Water and Electricity Consumption by Residential Customers (undated).

Romani, Mattia, James Rydge and Nicholas Stern, Recklessly Slow or a Rapid Transition to a LowCarbon Economy? Time to Decide, Policy Paper, (Grantham Research Institute, 2012).

Russell, James A., 'The Persian Gulf: Bahrain, Iran, Iraq, Kuwait, Qatar, Saudi Arabia, the United Arab Emirates, and Oman', in Daniel Moran (ed.), Climate Change \& National Security Washington D.C.: Georgetown University Press, 2011), 163-76. 
Salter, Robert, Subash Dhar and Peter Newman (eds.), Technologies for Climate Change Mitigation:

Transport Sector, TNA Guidebook (UNEP Risoe Centre, 2011).

Saudi Aramco, Saudi Aramco Environmental Stewardship (undated/2011 or 2012).

Sharma, Sudhir, and Denis Desgain, Understanding the Concept of Nationally Appropriate Mitigation Action (UNEP Risoe Centre, 2013).

Schwab, Klaus (ed.), The Global Competitiveness Report 2013-14. Full Data Edition, Insight Report (Geneva: World Economic Forum, 2013).

Smeets, Bram, and Ali Bayar, 'Sustainability of Economic Growth in Abu Dhabi - A Dynamic CGE Approach', Topics in Middle Eastern and African Economies, Vol. 41, September 2012, 6-48.

Tilburg, van, Xander, Sophy Bristow, Frauke Röser, Donovan Escalante and Hanna Fekete, Status Report on Nationally Appropriate Mitigation Actions (NAMAs): Mid-year Update June 2013 (Mitigation Momentum, 2013).

UNDP and Dubai Carbon, State of Energy Report: Dubai 2014 (Dubai: Dubai Supreme Council of Energy, 2013).

UNEP, Towards a Green Economy: Pathways to Sustainable Development and Poverty Eradication (Nairobi: UNEP, 2011).

UNFCCC, UNFCCC Resource Guide for Preparing National Communications of Non-Annex I Parties: Module 4: Measures to Mitigate Climate Change (Bonn: UNFCCC, 2008).

Waterbury, John, The Political Economy of Climate Change in the Arab Region, Arab Human Development Report Research Paper (UNDP Regional Bureau for Arab States, 2013).

World Resources Institute (WRI), 'Climate Analysis Indicators Tool (CAIT 2.0)' [cait2.wri.org/], accessed in October 2013.

WWF, Living Planet Report 2012: Biodiversity, Biocapacity and Better Choices (Gland: WWF, 2012).

\section{IPCC REPORTS}

Barker, T., et al., 'Summary for Policymakers', in B. Metz et al. (eds.), Climate Change 2007: Mitigation. Contribution of Working Group III to the Fourth Assessment Report (AR4) of the Intergovernmental Panel on Climate Change (IPCC) (Cambridge, UK and New York, US: Cambridge University Press, 2007).

Bernstein, L., et al., 'Industry', in B. Metz et al. (eds.), Climate Change 2007: Mitigation. Contribution of Working Group III to the Fourth Assessment Report (AR4) of the IPCC (Cambridge, UK and New York, US: Cambridge University Press, 2007).

Bogner, J., et al., 'Waste Management', in B. Metz et al. (eds.), Climate Change 2007: Mitigation. Contribution of Working Group III to AR4 of the IPCC (Cambridge, UK and New York, US: Cambridge University Press, 2007).

Gupta, S., et al., 'Policies, Instruments and Co-operative Arrangements', in B. Metz et al. (eds.), Climate Change 2007: Mitigation. Contribution of Working Group III to AR4 of the IPCC (Cambridge, UK and New York, US: Cambridge University Press, 2007).

Kahn Ribeiro, S., et al., 'Transport and Infrastructure', in B. Metz et al. (eds.) Climate Change 2007: Mitigation. Contribution of Working Group III to AR4 of the IPCC (Cambridge, UK and New York, US: Cambridge University Press, 2007).

Levine, M., et al., 'Residential and commercial buildings', in B. Metz et al. (eds.) Climate Change 2007: Mitigation. Contribution of Working Group III to AR4 of the IPCC (Cambridge, UK and New York, US: Cambridge University Press, 2007).

Sims, R.E.H., et al., 'Energy supply', in B. Metz et al. (eds.) Climate Change 2007: Mitigation. Contribution of Working Group III to AR4 of the IPCC (Cambridge, UK and New York, US: Cambridge University Press, 2007).

Smith, P., et al., 'Agriculture', in B. Metz et al. (eds.) Climate Change 2007: Mitigation. Contribution of Working Group III to AR4 of the IPCC (Cambridge, UK and New York, US: Cambridge University Press, 2007). 

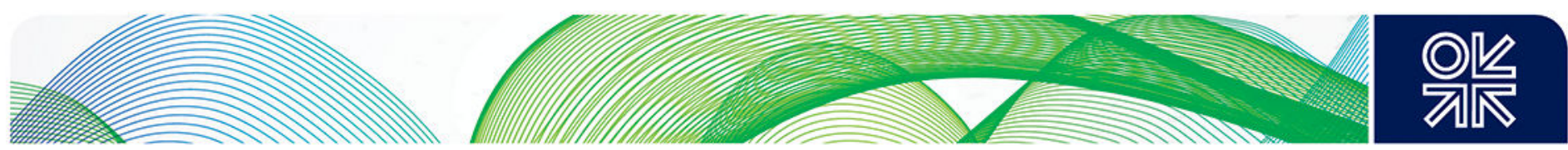

Stocker, Thomas F., et al. (eds.), Climate Change 2013: The Physical Science Basis. Summary for Policymakers. Working Group I Contribution to the Fifth Assessment Report (AR5) of the IPCC (Cambridge, UK and New York, US: Cambridge University Press, 2013).

\section{UNFCCC DECISIONS AND DOCUMENTS}

Kingdom of Bahrain Public Commission for the Protection of Marine Resources, Environment and Wildlife, Bahrain's Second National Communication UNFCCC (2012).

Kingdom of Saudi Arabia, Second National Communication (2011).

State of Kuwait Environment Public Authority, Kuwait's Initial National Communications under the UNFCCC (2012).

State of Qatar Ministry of Environment, Initial National Communication to the UNFCCC (2011).

Submission by Saudi Arabia, 'Views on the Fully Operational Prototype of NAMA Registry' (26 May 2013).

UAE Ministry of Energy, $3^{\text {rd }}$ National Communication under the UNFCCC (2012).

UNFCCC, United Nations Framework Convention on Climate Change (1992).

- Decision -/CP.19. Warsaw international mechanism for loss and damage associated with climate change impacts. (Document number $\mathrm{n} / \mathrm{a}$ in December 2013.)

—, Decision 1/CP.18, FCCC/CP/2012/8/Add.1.

- Decision 24/CP.18, FCCC/CP/2012/8/Add.3.

—, Decision 10/CMP.7, FCCC/KP/CMP/2011/10/Add.2.

—, Decision 1/CP.17, FCCC/CP/2011/9/Add.1.

— Decision 2/CP.17, FCCC/CP/2011/9/Add.1.

- Decision 1/CP.16, FCCC/CP/2010/7/Add.1.

- document FCCC/SBI/2013/INF.12/Rev.2.

- document FCCC/CP/2012/MISC.2.

- document FCCC/AWGLCA/2011/MISC.1.

— , document FCCC/AWGLCA/2009/MISC.1/Add.1.

- document FCCC/SBSTA/2009/MISC.6.

— , document FCCC/SBSTA/2007/MISC. 15.

\section{PRESENTATIONS}

Presentation in a Chatham House workshop: Approaching COP18: New Avenues for Enhancing Multilateral Action, Doha, 4 November 2012. (Chatham House rule applied.)

Al-Meshari, Ali A., 'Saudi Aramco's Efforts in Carbon Management', presentation, May 2013.

Alabbadi, Naif M., 'Saudi Energy Efficiency Center', presentation at the AFED $6^{\text {th }}$ Annual Conference, Sharjah, 28-29 October 2013.

__,'Energy Efficiency Potential in the Building Sector', presentation for the Saudi International Advanced Materials Conference, Riyadh, 3-4 December 2012.

Alam, Tanzeed, and Laila Abdullatif, 'The UAE Ecological Footprint', presentation on the UAE's work for the Living Planet Report 2010 (EWS-WWF, 2010).

Anastasia, Orestes, presentation: 'Foundations for Long-Term Sustainable Growth: Low Emission, Climate Resilient Development Strategies', The Asian and Pacific Regional Implementation Meeting on Rio + 20 Outcomes, Bangkok, 24 April 2013.

El-Badri, Abdalla S., 'The Global Energy Outlook', opening remarks to the International Energy Week, Moscow, 28 October 2013 [www.opec.org/opec_web/en/2641.htm], accessed in January 2014.

Kuwait Oil Company, 'Gas Flaring Reduction at Kuwait Oil Company', presentation, 13 February 2012.

Qatar Cool, presentation in Qatar-Korea Renewable Energy Seminar, Doha, October 2011.

Smith, Bruce, 'Demand Side Management - Plans and Challenges in Abu Dhabi', presentation, May 2012. 

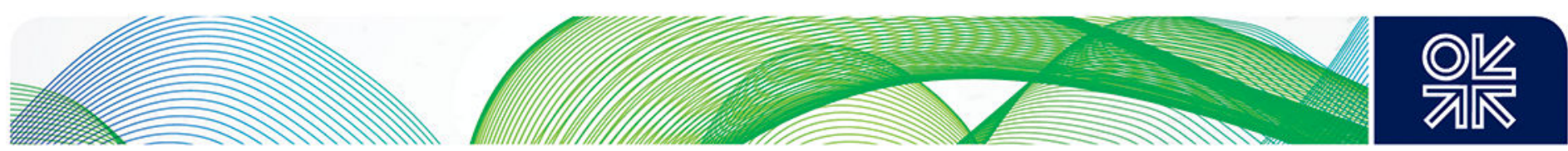

Sosa Iglesias, Gustavo, Methane Leakage and Flaring in Latin America and the Caribbean: Opportunities for Mitigation: Pemex's Practice', presentation in Intergovernmental Consultation on Near-Term Climate Protection and Clean Air for Latin America and the Caribbean, Bogotá, October-November 2012.

UNFCCC Consultative Group of Experts, 'CGE Training Materials: National Greenhouse Gas Inventories: Energy Sector - Fugitive Emissions', presentation, 2 April 2012.

\section{NEWSPAPER AND OTHER JOURNALISTIC SOURCES, PRESS RELEASES}

Abdul Kader, Binsal, 'Efforts to Control Abu Dhabi's High Rate of Per Capita Carbon and Water Footprints', Gulf News (28 July 2013).

_ , 'UAE to Announce Action Plan for Green Growth Strategy by End of This Year,' Gulf News (15 May 2013).

Ahmad, Anwar, 'CNG Vehicle Conversion Centre to Open in Northern Emirates', The National (9 October 2013).

Albawaba, 'Amidst the Sand, UAE is Going "Green" with First UN Green Economy Conference Scheduled for March' (13 November 2013).

Ali Khan, Ghazanfar, 'Pioneering Saudi Farm Techniques Bear Fruit', Arab News (23 September 2013).

Alnuam, Sami, 'Saudi Arabia's One More Go at a National Energy Strategy', Albawaba Business (29 September 2013).

AMEinfo, 'Kahramaa Celebrates its First Tarsheed Anniversary' (27 April 2013).

Amir, Yassir, 'Govt Can Derive Income from Waste Recycling', Arab News (8 July 2013).

Arab News, 'Kingdom to Use Shale Gas for Electricity Generation' (15 October 2013).

Balbo, Laurie, 'Ethihad[sic] Jet Uses Biofuels for Inaugural Home Run', Green Prophet (26 January 2012).

Bernier, Aurèlien, 'Ecuador's Plan Falters', Le Monde Diplomatique (July 2012).

BusinessGreen, 'Masdar Digs Deep for Middle East's First Carbon Capture Project' (14 November 2013).

CA News Network, 'KSA is LEED-ing the Way to a Sustainable Design of Undergoing Building Projects', Construct Arabia (5 March 2013).

Carter, Ryan, 'New Taps to Curb Abu Dhabi Water Usage', The National (18 April 2013).

Collins, Laura, 'The Real Cost of Water and Electricity Will Shock You', The National (7 April 2012).

Construction Week Online, 'DEWA Succeeds in Cutting Grid Power Losses' (24 September 2013).

_ , 'Saudi Solar-Powered Desal Plant Ready by Year-End' (27 August 2013).

Douglass, Elizabeth, 'Investor Group Presses Oil Companies on "Unburnable Carbon"', Bloomberg (24 October 2013).

EAD, 'EAD and Key Government Partners Helping to Shape Abu Dhabi's Climate Change Strategy', press release (8 October 2013).

Emirates Nuclear Energy Corporation, 'Construction of the UAE's Second Nuclear Power Plant Gets Underway', press release, 28 May 2013.

Everington, John, 'Masdar Invests in Jordan's First Major Wind Farm', The National (28 November 2013).

Figueres, Christiana, 'Christiana Figueres: Global Deal on Climate Change Complex But Possible', RTCC (5 February 2013).

Gale, Ivan, 'Qatar Airways Heralds Biofuels Programme', The National (19 January 2010).

Gillis, Justin, 'Climate Change Seen Posing Risk to Food Supplies', New York Times (1 November 2013).

Harvey, Fiona, 'IPCC's “Carbon Budget” Will Not Drive Warsaw Talks, Says Christiana Figueres', The Guardian (24 October 2013).

John, Isaac, 'Dubai Municipality to Cut Power, Water Use', Khaleej Times (8 August 2012).

Kahramaa, 'New Qatari Standards for AC Energy Efficiency', press release (4 August 2013). 
Kannan, Preeti, 'UAE Devises Green Strategy to Unify Existing Policies', The National (17 December 2013).

Khaleej Times, 'UAE Diversifying Resources' (15 October 2013).

King, Ed, 'Masdar Aims to Boost Renewable Investments after London Array Success', RTCC (9 July 2013),

_ , 'Qatar, Saudi Arabia, Bahrain \& UAE Make Mysterious Climate Pledge', RTCC (7 December 2012).

Kloosterman, Karin, 'Dubai Opens 13 MW Solar Plant, the Largest PV Plant in Mideast', Green Prophet (23 October 2013).

Kyu-wook, Oh, 'Korean Institute and Saudi Aramco Agree to Establish CCS Research Centre', The Korea Herald (11 January 2013).

Mathew, Ramesh, 'Mowasalat to Operate 63 more CNG buses'. Gulf Times (17 September 2013).

-, 'Karwa Receives First CNG-Run Car', Gulf Times (30 April 2013).

Mills, Robin, 'A Lot of Work Ahead for Dubai's Green Energy Plans to Take Shape', The National (27 October 2013).

Neuhof, Florian, 'Dubai Looks to Rooftop Solar Power Revolution', The National (13 May 2013).

Potsdam Institute for Climate Impact Research, "Promoting evidence-based decision-making": Qatar and PIK announce creation of climate change research institute', press release (5 December 2012).

Renewable Energy Focus, 'Masdar PV Abandons Plans for UAE Solar Manufacturing Hub' (13 January 2011).

Reuters, 'Germany's Linde to Build Big Saudi Carbon Capture-and-Use Plant' (21 August 2013).

—_, 'Qatar Working on 1,800 Solar Project', Trade Arabia (1 December 2012).

__ 'Saudi King Says Keeping Some Oil Finds for Future', Reuters (13 April 2008).

Solomon, Jay, and Margaret Coker, 'Oil-Rich Arab State Pushes Nuclear Bid with U.S. Help', The Wall Street Journal (2 April 2009).

Soto, Michelle M., 'Costa Rica crea mercado local de carbono', La Nación (11 September 2013).

Sushma U. N., 'Solar Power's Moment under the Indian Sun', The Times of India (30 September 2013).

Taylor, Brian, and Dan Sandoval, 'A Bright Future', Recycling Today (8 May 2013).

The Economist, 'Unburnable Fuel' (4 May 2013).

_- 'Carbon Markets: Complete Disaster in the Making' (15 September 2012).

The Peninsula, 'Qatari Govt Receives National Food Security Plan from QNFSP' (27 August 2013).

Todorova, Vesela, 'Experts Discuss Carbon Capture in Abu Dhabi' The National (8 November 2013).

—_, 'UAE Working Hard to Reduce Waste', The National (5 July 2013).

— - 'Clean Fuels Top UAE's Green Strategy' (14 May 2013).

—_, Masdar Students' Energy and Water Use Monitored', The National (28 April 2011).

_- 'Shoppers Presented with Energy-Saving Light Bulbs', The National (9 August 2010).

_ - 'Homes to Be Fitted with Free Water-Saving Devices', The National (21 May 2010).

UAE Interact, 'Dubai Municipality Takes Further Step Towards Being Most Sustainable City in World with LED Lighting' (2 October 2013).

UN News Centre, 'Outdoor Air Pollution a Leading Cause of Cancer, Say UN Health Experts' (17 October 2013).

WAM, WAM, 'From Waste to Energy: Landfill Site Generates Electricity - First in the Region', (1 August 2013).

_ 'Energy Rating Labels to Be Displayed on All UAE Appliances', UAE Interact (9 July 2013).

—. 'Dubai's Energy Growth Set to Be 4-5\% by 2030', Emirates 24/7 (24 October 2012).

-, 'Mohamed Unveils UAE's Green Economy' (15 January 2012).

Zafar, Salman, 'CDM Projects in MENA Region', EcoMENA (7 April 2013). 

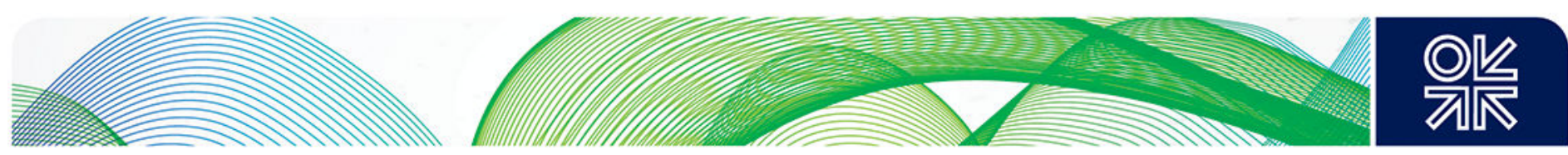

\section{WEB SOURCES}

Abu Dhabi Sustainability Group, 'About Us' [http://www.adsg.ae/about/Pages/AboutUsHome.aspx], accessed in October 2013.

CDM-DNA UAE, 'DNA UAE' [http://www.cdm-uae.ae/portal/menu.authority.aspx], accessed in October 2013.

Climate and Clean Air Coalition, 'Short-Lived Climate Pollutants' [http://www.unep.org/ccac/ShortLivedClimatePollutants/tabid/101650/Default.aspx], accessed in October 2013.

Dubai Global Energy Forum, 'Dubai Supreme Council of Energy’ [http://www.dgef.ae/sce.aspx], accessed in October 2013.

DUBAL, 'Energy conservation at DUBAL' [http://www.dubal.ae/how-we-care/optimising-energyefficiency/energy-conservation-at-dubal.aspx], accessed in November 2013.

Ecofys, 'What's included in the database?' (3 September 2013) [http://www.namadatabase.org/index.php/What\%27s_included_in_the_database\%3F], accessed in October 2013.

Estidama, 'Pearl Building Rating System' [http://estidama.org/pearl-rating-system-v10/pearl-buildingrating-system.aspx], accessed in October 2013.

Global CCS Institute, 'The Global Status of CCS: 2013; Appendix E: Existing $\mathrm{CO}_{2}$ Transport Infrastructure' [http://www.globalccsinstitute.com/publications/global-status-ccs2013/online/118026], accessed in November 2013.

Global Footprint Network, 'Carbon Footprint' [http://www.footprintnetwork.org/pt/index.php/GFN/page/carbon_footprint/], accessed in October 2013.

Global Gas Flaring Reduction Partnership, 'Estimated Flared Volumes from Satellite Data, 20072011' [http://go.worldbank.org/G2OAW2DKZ0], accessed in November 2013.

Heroes of the UAE website [http://www.heroesoftheuae.ae/en], accessed in November 2013.

IISD-RS Video: \#2-12: UNFCCC - Bonn Climate Change Conference

[http://www.iisd.ca/videos/climate/unfccc-sb38/\#video], accessed in November 2013.

International Carbon Action Partnership, 'Interactive ETS Map'

[http://icapcarbonaction.com/index.php?option=com_wrapper\&view=wrapper\&ltemid=147], accessed in October 2013.

Intertek, 'Energy Efficiency Label Testing - Kingdom of Saudi Arabia (KSA)' [http://www.intertek.com/appliances-electronics/energy-efficiency/ksa-label/], accessed in December 2013.

IPCC, 'Adaptation and Mitigation Options' [http://www.ipcc.ch/publications_and_data/ar4/syr/en/spms4.html], accessed in November 2013.

K.A.CARE, 'Sustainable Energy' [http://www.kacare.gov.sa/en/sustainable-energy/sustainableenergy], accessed in October 2013.

KAUST, 'Sustainable Development' [http://www.kaust.edu.sa/about/sustainable/sustainable.html], accessed in October 2013.

LEDS Global Partnership, 'LEDS Support Programs' [http://ledsgp.org/activities/all], accessed in October 2013.

Levin, Kelly, 'World's Carbon Budget to Be Spent in Three Decades', WRI Insights (27 September 2013) [http://insights.wri.org/news/2013/09/world\%E2\%80\%99s-carbon-budget-be-spent-threedecades], accessed in November 2013.

Masdar City, 'Frequently Asked Questions' [http://masdarcity.ae/en/110/frequently-asked-questions/], accessed in October 2013.

Masdar Clean Energy, 'About Masdar Clean Energy' [http://www.masdar.ae/en/energy/detail/masdarclean-energy-who-we-are], accessed in December 2013.

Ministry of Energy and Industry (Qatar), 'Qatar Launches Project to Produce Electricity from Solar in Parallel with the COP18' [http://www.mei.gov.qa/news-en/Qatar-launches-project-to-produceelectricity-from-solar-in-parallel-with-the-COP18/67/], accessed in October 2013. 
NAMA Wiki, 'What Are NAMAs' [http://namapartnership.wikispaces.com/What+are+NAMAs\%3F], accessed in October 2013.

National Communications Support Programme website [http://ncsp.undp.org/], accessed in December 2013.

OAPEC, 'Biography of H.E. Secretary General, OAPEC' [http://www.oapecorg.org/sgecv.html], accessed in October 2013.

OECD 'Green Growth in Action: Korea' [http://www.oecd.org/korea/greengrowthinactionkorea.htm], accessed in October 2013.

Omanuna, 'Our Environment' [http://www.oman.om/wps/portal/lut/p/c4/04_SB8K8xLLM9MSSzPy8xBz9CP0os3hjA3cDA39LT1 8Tp0AXAyMvl2_TYEdj14NgE_2CbEdFAJCSMWg!/?WCM_PORTLET=PC_7_30G0009IMSB91 02BG2LM6PHSO3000000_WCM\&WCM_GLOBAL_CONTEXT=/wps/wcm/connect/ar/site/home/ environment/envior\#p2], accessed in October 13.

OpenEI, 'Low Emission Development Strategies (LEDS) Gateway' [http://en.openei.org/wiki/Gateway:Low_Emission_Development_Strategies], accessed in December 2013.

PBL Netherlands Environmental Assessment Agency, 'Countries' Contributions to Climate Change: Effect of Accounting for All Greenhouse Gases, Recent Trends, Basic Needs and Technological Progress' (31 October 2013) [http://www.pbl.nl/en/publications/countries-contributions-to-climatechange], accessed in November 2013.

Point Carbon [http://www.pointcarbon.com/], accessed in November 2013.

Qatar Cool, 'Our Customers' [http://www.qatarcool.com/ourcustomers.php], accessed in October 2013.

Qatar Energy \& Industry Sector Sustainability Report 2012, 'Investing in Energy Opportunities' [http://www.hse-reg-dg.com/qeisr2012/WWW/climate/investing-in-energy/], accessed in November 2013.

Qatar National Food Security Programme (QNFSP), [http://www.qnfsp.gov.qa/], accessed in December 2013.

Qatar Solar Technologies, 'Project Update' [http://www.qstec.com/about/project-update], accessed in November 2013.

Qatar Sustainability Network, 'Members' [http://www.qsnetwork.org/], accessed in October 2013.

State of the Environment Norway, 'Climate Change' [http://www.environment.no/Goals-andindicators/Goals-and-indicators/Climate-change/], accessed in October 2013.

UAE Cabinet, 'A Green Economy for Sustainable Development,' [http://www.uaecabinet.ae/], accessed in December 2012.

UAE Ministry of Foreign Affairs, 'Energy \& Climate Change' [http://www.mofa.gov.ae/mofa_english/portal/2666c727-3cea-4483-9791-56462f752166.aspx], accessed in October 13.

UNDESA, United Nations Sustainable Development Knowledge Platform, 'Low Carbon Development' [http://sustainabledevelopment.un.org/index.php?menu=1448], accessed in October 2013.

UNDP, 'Green LECRDS Guidance Manuals and Toolkits'

[http://www.undp.org/content/undp/en/home/ourwork/environmentandenergy/focus_areas/climate _strategies/green_lecrds_guidancemanualsandtoolkits/], accessed in December 2013.

_ _ ' 'Green, Low-emission and Climate Resilient Development Strategies'

[http://www.undp.org/content/undp/en/home/ourwork/environmentandenergy/focus_areas/climate _strategies.html], accessed in December 2013.

UNFCCC, 'Adaptation' [http:// unfccc.int/adaptation/items/4159.php], accessed in November and December 2013.

_ , 'Capacity-Building: Background'

[http://unfccc.int/cooperation_and_support/capacity_building/items/7061.php], accessed in

December 2013.

__, 'National Focal Points' [http://maindb.unfccc.int/public/nfp.pl]; 'Designated National

Authorities' [http://cdm.unfccc.int/DNA/index.html], accessed in October 2013. 

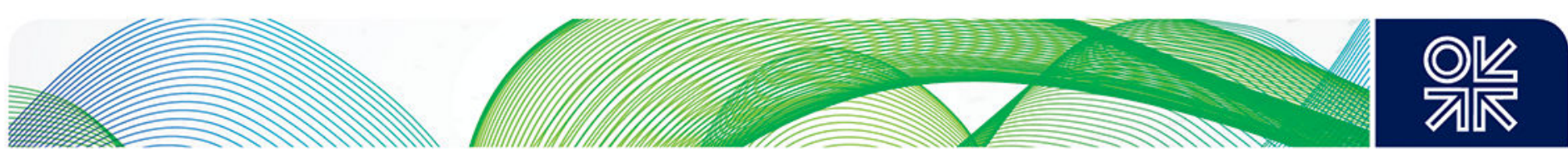

'Non-Annex I national communications' [http://unfccc.int/national_reports/nonannex_i_natcom/items/2979.php], accessed in October 2013.

, 'Relevant guidelines/manuals related to NCs and BURs from non-Annex I Parties' [http://unfccc.int/national_reports/nonannex_i_natcom/guidelines_and_user_manual/items/2607.php], accessed in October 2013

US Energy Information Administration (US EIA), 'International Energy Outlook 2013' [http://www.eia.gov/forecasts/ieo/emissions.cfm], accessed in October 2013.

_ - 'International Energy Outlook 2013, Table 21.' [http://www.eia.gov/forecasts/ieo/table21.cfm], accessed in October 2013.

UNFCCC CDM, 'Governance' [http://cdm.unfccc.int/EB/governance.html], accessed in October 2013.

Wilson, Lindsay, 'Average Household Electricity Use Around the World' [http://shrinkthatfootprint.com/average-household-electricity-consumption], accessed in November 2013.

World Bank, 'World Development Indicators' [http://databank.worldbank.org/], accessed in October 2013.

_, 'Climate Change' [http://wbi.worldbank.org/wbi/about/topics/climate-change], accessed in December 2013.

World Resources Institute (WRI), CAIT 2.0: Country Greenhouse Gas Sources \& Methods (WRI, 2013).

, CAIT 8.0 (Washington D.C., 2011).

-, 'Climate Analysis Indicators Tool (CAIT 2.0)' [cait2.wri.org/], accessed in October 2013. 